\title{
"Si en miembros no robusto": el retrato ecuestre de las Soledades y la maniera suave
}

\author{
Humberto Huergo Cardoso \\ Carleton College
}

Título: "Si en miembros no robusto": el retrato ecuestre de las Soledades y la maniera suave.

Resumen: Decía Daniele Barbaro que la pintura representa "una ternura en el horizonte de nuestra vista que es y no es". El presente trabajo no vuelve sobre si la figura ecuestre de la segunda Soledad es un criptorretrato del XI conde de Niebla, sino de qué tipo de retrato se trata. ¿El de un mancebo delicado que enfrena suavemente un caballo azul celeste? ¿Quién ha visto un retrato ecuestre de semejantes características cuando el género siempre ha representado la cima de la masculinidad y el patriotismo? ¿Qué significa la "suavidad" de Góngora y qué relación guarda con la maniera del Greco?

Palabras clave: Conde de Niebla, El Greco, homosexualidad, pintura de borrones, retrato ecuestre.

Fecha de recepción: 02/03/2021.

Fecha de aceptación: 11/03/2021.
Title: "Si en miembros no robusto": the Equestrian Portrait of the Solitudes and the Soft Maniera.

Abstract: Daniele Barbaro once said that painting is "a tenderness in the horizon of vision that is and is not". The focus of my paper is not whether the equestrian character of the second Soledad alludes to the XI count of Niebla or not, but rather what kind of portrait it is. An equestrian portrait of a delicate young man who pulls softly on the reins of a bluish white horse? Who has ever seen a royal equestrian portrait of such characteristics when the genre has always embodied the pinnacle of virility and patriotism? What does Góngora's "softness" mean and how does it relate to the Mannerism of El Greco?

Key words: Count of Niebla, equestrian portrait, El Greco, homosexuality, picturesque.

Date of Receipt: 02/03/2021.

Date of Approval: 11/03/2021. 
"lo robusto / trocó"

Góngora, Las firmezas de Isabela

\section{Aun de SEDA No haY víNCUlo süAVE}

$\mathrm{Al}$ fondo del retrato se escuchan los gemidos de un perro que protesta por verse atado a una "laja", una cuerda laxa':

Número y confusión gimiendo hacía

en la vistosa laja, para él grave,

que aun de seda no hay vínculo süave.

(Sol. 2, vv. 806-808).

No hay vínculo que sea suave. No hay vincular, atar, sujetar que no imponga un orden reductor en lo que hasta entonces era un campo abierto de posibilidades. Uno de los dilemas poético-filosóficos más acuciantes de Góngora será cómo vincular las palabras sin renunciar a la suavidad, o, para decirlo de otro modo, cómo articular libertad y necesidad ${ }^{2}$, llanto y metro ("métrico llanto") 3 , voz y sangre ("voces de sangre") 4 , "número y confusión", el orden y la aventura. Si se impone la medida, perdemos el llanto y la voz se desangra; la poesía se vuelve pura palabrería. Pero sin el vínculo del metro el verso se ahoga en un mar de lágrimas y tampoco dice nada. El quid está en conciliar la voz y el llanto, el impulso formal y el impulso material de manera que el sentido no se agote en el mensaje sino que conserve siempre un margen de indeterminación que trascienda la mera palabrería. El dulce lamentar de los pastores en las églogas y en

1 Luis de Góngora, Soledad segunda, v. 808. Salvo indicación contraria, todas las citas de las obras de Góngora provienen de la edición de las Obras completas a cargo de Antonio Carreira, Madrid, Fundación José Antonio de Castro, 2000, 2 vols. Para el caso de las Soledades, abrevio Sol. 1, v. 20, es decir, Soledad primera, verso 20. En el resto de los casos, abrevio $O C$, I, núm. 20, v. 40, es decir, Obras completas, t. 1, poema número 20 , verso 40 .

2 Friedrich Schiller, Cartas sobre la educación estética de la humanidad, trad. Eduardo Gil Bera, Barcelona, Acantilado, 2018, p. 74.

3 Góngora, Sol. 2, v. 115.

4 Góngora, ibidem, v. 119. 
la novela pastoril da amplia muestra de ello. "Salid lágrimas corriendo": no hay género que exprese mejor el vínculo de seda que une y desune el metro y el llanto. ¿El plan de las Soledades? "La dialéctica del plan y del no plan"s; menos una forma determinada de antemano que esa "mezcla de incertidumbre y seguridad" que Pareyson llama formatividad". Schiller lo formula en términos ligeramente distintos: "La belleza produce un doble efecto, de distensión y de tensión" ". Tender y distender a un mismo tiempo, sin renunciar al número, pero tampoco a la confusión.

\section{Si TU NEUTRALIDAd SUfRE CONSEJO}

Así empieza el retrato, envuelto en suavidad:

Que aun de seda no hay vínculo süave.

En sangre claro y en persona augusto,

si en miembros no robusto,

príncipe les sucede, abrevïada

en modestia civil real grandeza.

La espumosa del Betis ligereza

bebió no sólo, mas la desatada

majestad en sus ondas el luciente

caballo, que colérico mordía

el oro que süave lo enfrenaba,

arrogante, y no ya por las que daba

estrellas su cerúlea piel al día,

sino por lo que siente

5 Roland Barthes, Lo neutro. Notas de cursos y seminarios en el Collège de France, 19771978, eds. Thomas Clerc y Beatriz Sarlo, trad. Patricia Willson, Buenos Aires, Siglo XXI, 2002, p. 57.

6 Luygi Pareyson, Estética. Teoría de la formatividad (1954), ed. y trad. Cristina Coriasso Martín-Posadillo, Madrid, Xorki, 2014: "El tantear no es tan incierto como para reducirse a un mero andar a tientas, ni tan seguro como para tomar la vía regia: más bien está constituido por una mezcla de incertidumbre y seguridad, en que, mientras dura la búsqueda, el riesgo no instaura el reino del azar y la esperanza no se transforma aún en certeza. La tentativa tiene a la vez algo de desordenado y de ordenado" (p. 119).

7 Schiller, op. cit., p. 81. 
de esclarecido, y aun de soberano, en la rienda que besa la alta mano de cetro digna. Lúbrica no tanto. (Sol. 2, vv. 808-823).

Antes de entrar en materia, le pido al lector que repase por encima, sin esforzarse todavía por entender demasiado — sin esforzarse por vincular-, las palabras que componen el retrato: seda, vinculo süave, espumosa, ligereza, desatada, luciente, oro (por freno de oro) y süave lo enfrenaba.

Añádanse ahora una lítote, no robusto, y cuatro negaciones seguidas: no hay, bebió no, no ya, no tanto, sin contar el eco repetido de las voces sino, soberano y mano. No, no y no.

Se diría que no hay tanto retrato, la representación positiva de un objeto, cuanto una pintura de borrones en la que todo lo que queda del "freno" del caballo es una mancha luciente: "el oro que süave lo enfrenaba". El Panegírico al conde de Niebla (1629) de Espinosa no dice otra cosa: “ $A$ los caballos desvaneciste [el conde de Niebla] con la ufanía de tanto oro; y el adorno era lo principal, y ellos, lo accesorio" ". Desatada majestad, el objeto de la representación se desvanece detrás de la orquesta de los metales. La imagen surge en medio del desvanecimiento. Habrá un retrato, pero sin renuciar a la negatividad: mano de cetro [...] no tanto.

Podríamos decirlo de otro modo: "Si tu neutralidad sufre consejo, / y no te fuerza obligación precisa, / la piedad que en mi alma ya te hospeda / hoy te convida" (Sol. 1, vv. 518-521). Piedad del alma y neutralidad del verso. El texto convida al lector a deponer un momento las obligaciones que lo fuerzan, todas precisas, y a hallar refugio en la neutralidad de un decir que ni habla ni calla, ni ata ni desata, sino que simplemente "sugiere" (Valéry) ${ }^{9}$; un decir impreciso, o, mejor, de una imprecisa exactitud; "fábrica escrupulosa, y aunque incierta, / siempre murada ['cercada'], pero siempre abierta” (Sol. 2, vv. 79-80).

8 Pedro Espinosa, Obra en prosa, ed. Francisco López Estrada, Málaga, Diputación Provincial de Málaga, 1991, pp. p. 343.

9 Paul Valéry, Cuadernos (1894-1945), ed. Andrés Sánchez Robayna, trads. Maryse Privat, Fátima Sainz y Andrés Sánchez Robayna, Barcelona, Galaxia Gutenberg, 2007: “Agotar lo 'sugestivo' mediante la fijación del desorden de las palabras extremas conjuntas, por disonancias” (p. 423). La afinidad que existe entre ambos escritores está todavía por estudiarse. No es poca. 
La fábrica del decir no está abierta ni cerrada. Está cerrada en lo abierto y abierta en lo cerrado. Siempre se da; Góngora siempre cede, pero sin renunciar al "no de retiramiento", sin renunciar a la negatividad ${ }^{10}$.

"Neutralidad" es neologismo gongorino del que se burla Quevedo en el soneto "Receta para hacer Soledades en un día": "Poco, mucho, si no, purpuracía, / neutralidad"11. Incluso cita verbatim el verso que acabo de glosar y que para el autor del Buscón representaba el epítome de la ridiculez: "Muda costumbres antes que pellejo, / si tu neutralidad sufre consejo" 12 ¿Qué era aquello de "neutralidad"? ¿Qué quería nombrar Góngora que no podía nombrar con el español de Covarrubias?

Según la tardía definición de "neutralidad" del Diccionario de Autoridades (1734), quería nombrar una cierta "indiferencia o indeterminación" con respecto al propio nombrar ${ }^{13}$. Un nombrar que no cerrara lo nombrado, que no lo fijara dentro de los límites de la definición. Nombrar sin que lo fuerce obligación precisa y sin robarle al objeto la suavidad que le es propia.

Ni A ni lo contrario de A; ni poco ni mucho, protesta Quevedo; ni sí ni no: "una aprehensión generosa y libremente difusa [a large and freely diffused apprehension]"14; "esquives de la afirmación [esquives de l'affirmation]"15.

10 José Lezama Lima, "Sierpe de don Luis de Góngora” (1951), en Analecta del reloj, La Habana, Orígenes, 1953, pp. 183-214 (p. 202).

11 Francisco de Quevedo, Obras completas. I. Poesía original, ed. José Manuel Blecua, Barcelona, Planeta, 1963, p. 1161, vv. 5-6.

12 Francisco de Quevedo, "Alguacil del Parnaso, Gongorilla", ibidem, p. 1183, v. 107.

13 Diccionario de Autoridades, ed. facsímil, 3 tomos, Madrid, Gredos, 2002, s. v. neutralidad.

14 François du Jon, Franz Junius o Franciscus Junius, The Painting of the Ancients (1638), eds. Keith Aldrich, Philipp Fehl y Raina Fehl, traducido del latín por el propio Junius, Berkeley, The University of California Press, 1991: "Así como es obvio que nuestra curiosidad no debe ocuparse de asuntos mezquinos y triviales, así debemos nosotros, bien al contrario, tratar de concebir toda la manifestación de las cosas representadas con una aprehensión generosa y libremente difusa [as it is then evident that our curiositie may not busie itselfe too much about poore and frivolous matters, so must wee on the contrary endeavour to conceive the whole shew [show] of the represented matters with a large and freely diffused apprehension]" (t. 1, lib. 3, cap. 7, p. 302).

15 Barthes, op. cit., p. 95: "Todo lo neutro es esquive de la aserción (= tema general del curso). No planteo más que el principio de un 'dossier' referido a los esquives de la afirmación”. El sueño de Góngora: escribir sin afirmar. 


\section{3. ¿QUIÉN ES EL MALO?}

Durante siglos, el interés de la crítica gongorina por el retrato ecuestre de las Soledades se ha limitado a despejar la identidad del cazador, sin que la efigie en sí misma parezca importar demasiado. Lo decisivo ha sido siempre el quién y el dónde: quién es el príncipe y dónde exactamente transcurre la acción.

Pellicer ("la intención de don Luis fue pintar aquí al señor duque de Béjar") ${ }^{16}$, Salcedo Coronel ("describe luego hermosamente el caballo en que iba este príncipe, que a lo que puedo conjurar supone que era el excelentísimo duque de Béjar")17, y Angulo y Pulgar ("la admirable pintura del duque de Béjar y su caballo, y del estruendo y aparato de su cetrería, es muy singular") ${ }^{18}$, se decantan por Alonso Diego López de Zúniga y Sotomayor, con mayor o menor grado de convencimiento ${ }^{19}$.

En cambio, en nuestros días predomina la creencia de que se trata "evidentemente" del conde de Niebla:

16 José de Pellicer de Salas y Tovar, Lecciones solemnes a las obras de don Luis de Góngora y Argote (1630), Hildesheim, Baja Sajonia, Georg Olms, 1971, col. 598.

17 García de Salcedo Coronel, Soledades de don Luis de Góngora, comentadas, Madrid, Imprenta Real, 1636, f. 295v. Adelantándose a la tesis de Jammes, un lector anónimo del texto de Salcedo escribió en el margen: "Duque de Béjar no me parece que sea, pues supone este comentador que este naufragio fue en Italia como afirma en la 1 Soledad, fol. 19; y en la 2, fol. 271. Yo entiendo que era el duque de Medina Sidonia y que este naufragio fue en el condado de Niebla, tierra suya”. Ver al respecto Juan Manuel Rozas, "Otro lector de Góngora disconforme con Salcedo", Revista de Filología, XLVI, 3/4 (1963), pp. 441-443 (p. 442). No obstante, como explica Rozas, "algunas de estas apostillas son bastante peregrinas e, incluso, errores garrafales" (p. 443). Citan el artículo Antonio Mira Toscano y Juan Villegas Martín, "Góngora y el paisaje de la Soledad Segunda. El litoral onubense en torno a 1600”, en El duque de Medina Sidonia: Mecenazgo y renovación estética, eds. José Manuel Rico García y Pedro Ruiz Pérez, Huelva, Universidad de Huelva, 2015, pp. 325-346 (p. 327, n. 6).

18 Martín de Angulo y Pulgar, Epistolas satisfactorias, en Las Epistolas satisfactorias (Granada, 1635) de Martín de Angulo y Pulgar, ed. Juan Manuel Daza Somoano, Sevilla, Universidad de Sevilla, 2019, pp. 234-367 (p. 343).

19 Véase asimismo Rafael Bonilla Cerezo y Paolo Tanganelli, Soledades ilustradas. Retablo emblemático de Góngora, Salamanca, Delirio, 2013, pp. 31-41. 
Para el que ha leído el poema desde el principio — afirma Jammes-, es evidente que este retrato no es el de un personaje ficticio. Pellicer y Salcedo [y Angulo y Pulgar, habría que añadir] supusieron, muy lógicamente, que se trata del prócer a quien está dedicado el poema [...] Pero sabemos, gracias al poeta Pedro Espinosa, que lo explica detalladamente en su Elogio al retrato del excelentísimo señor don Manuel Alonso Pérez de Guzmán el Bueno, publicado en 1625, que este "príncipe" es el conde de Niebla (a quien está dedicado el Polifemo $)^{20}$.

"Detalladamente" quizá sea mucho decir. Por lo que se refiere a Góngora, le dedica una línea que no repite en el Panegírico al conde de Niebla (Sevilla, 1629): "En esta soledad [Huelva] le halló el príncipe de los poetas don Luis de Góngora cuando dijo: 'En sangre claro y en persona rebusto [sic], / si en miembros no robusto, / príncipe le sucede”, etc. ${ }^{21}$ Lo cual no ha impedido que la tesis de Jammes se haya esparcido como la pólvora y goce del favor casi unánime de la crítica góngorina: entre otros, Daza Somoano $^{22}$, Lara Ródenas ${ }^{23}$, López Bueno ${ }^{24}$, Ly ${ }^{25}$, Mira Toscano y Rivera Martín ${ }^{26}$, y Ponce Cárdenas ${ }^{27}$. La excepción más notable, si bien no la única $^{28}$, se debe a Carreira, que desde 1994 viene expresando sus dudas:

20 Robert Jammes, "Introducción" a su edición de las Soledades, p. 544, n. 811.

21 Espinosa, op. cit., pp. 265-266. Como anota López Estrada, "el impreso trae por error: rebusto" (p. 266, n. 92).

22 Juan Manuel Daza Somoano, op. cit., p. 343, n. 497.

23 Manuel José de Lara Ródenas, "Los muros de Huelva: el conde de Niebla Manuel Alonso Pérez de Guzmán y su retiro en el castillo onubense", en El duque de Medina Sidonia, pp. 299-323 (pp. 307 y 318-319).

24 Begoña López Bueno, "Soledades polifónicas: Pedro Espinosa vs. Góngora”, en $L a$ Edad del Genio: España e Italia en tiempos de Góngora, eds. Begoña Capllonch, Sara Pezzini, Giulia Poggi y Jesús Ponce Cárdenas, Pisa, ETS, 2013, pp. 295-316 (p. 310).

25 Nadine Ly, "De sublimes y modestas cumbres: la figura del conde de Niebla en la segunda Soledad” (2015), en Lecturas gongorinas. De gramática y poesía, ed. Emre Özmen, Córdoba, Universidad de Córdoba, 2020, pp. 483-503.

26 Mira Toscano y Villegas Martín, op. cit., p. 339.

27 Jesús Ponce Cárdenas, "Góngora y el conde de Niebla. Las sutiles gestiones del mecenazgo", Criticón, 106 (2009), pp. 99-146 (p. 123 y passim).

28 Ver, por ejemplo, Gaspar Garrote Bernal, "Palabras por patrocinio. Cristóbal de Mesa ante el duque de Béjar (Rimas, 1611)", en El mecenazgo literario en la casa ducal de Béjar durante la época de Cervantes, ed. José Ignacio Díez Fernández, Burgos, 
"Es sospechoso el episodio biográfico del conde de Niebla, que no parece estar documentado" 29 . Sospecha que en el reciente "Las Soledades y la crítica posmoderna" (2014) se transforma en certeza: "No está nada claro de dónde sacó Pedro Espinosa su conjetura de que los versos [de Góngora] aluden al conde de Niebla; más bien parece cosa de su propia Minerva" ${ }^{30}$. ¿Es "evidente" (Jammes) o "no está nada claro" (Carreira)? Aunque el objetivo de este trabajo no persiga en absoluto despejar la identidad del 'principal' de las Soledades - lo que me interesa es explicar, sin escurrir el bulto y con la mayor precisión posible, el qué de la suavidad de Góngora y El Greco- - lo cierto es que la balanza podría caer de cualquier lado.

A favor de la hipótesis de Jammes se podría argüir que el conde de Niebla no sólo era cetrero, como el príncipe del poema (Fig. 1), sino Cazador Mayor de Volatería de Felipe III, dignidad que destacan Espinosa ("si vuela halcones, de tantos y tan puntuales criados se sirve en el cielo como en la tierra: tal, que, siendo conde, mereció título de Cazador Mayor de su Majestad") 31 , Mariner ("siendo ellos mismos [los reyes] cazadores, él [el conde de Niebla] fue prefecto del rey / y entregó sus favores

Fundación Instituto Castellano y Leonés de la Lengua, 2005: "Cuando mandó [el duque de Béjar] llamar a Mesa, cazando en sus posesiones andaluzas pasaba su tiempo el Duque, y en el correspondiente pasaje de esta epístola (vv. 88-93) aletean argumentos gongorinos de la segunda Soledad que pudieran hacer dudar de que Góngora (II, 809-823) retrató cazando al conde de Niebla y no al duque de Béjar, como sostiene Jammes" (pp. 131-173 [p. 150]); y Marsha S. Collins, The Soledades, Góngora's Masque of the Imagination, Columbia (Misuri), University of Missouri Press, 2002: "Sospecho que a Góngora le complacían las especulaciones acerca de la identidad del jinete, pero no creo que en realidad buscara representar a ningún individuo específico, sino captar la esencia o las ideas universales que conforman la base de este tipo de retrato [I suspect Góngora relished speculations over the identity of the horseman, but I believe that in actuality he sought not to represent a specific individual, but rather to capture the essence, the universal ideas that form the conceptual core of this particular type of portraiture]" (pp. 90-91).

29 Antonio Carreira, "Pedro Espinosa y Góngora", Revista de Filología Española, LXXIV, 1/2 (1994), pp. 167-179 (p. 173).

30 Antonio Carreira, "Las Soledades y la crítica posmoderna", en Góngora y su estela en la poesía española e hispanoamericana (el Polifemo y las Soledades en su IV Centenario), ed. Antonio Castro Díaz, Sevilla, Asociación Andaluza de Profesores de Español Elio Antonio de Nebrija, 2014, pp. 80-108 (p. 104).

31 Espinosa, op. cit., p. 243. 
en los bosques") 32, y el propio Góngora en el Polifemo (“peinar el viento, fatigar la selva") ${ }^{33}$. De hecho, y como recuerda Lara Ródenas, "una de las primeras órdenes que dio [el conde] a raíz de su establecimiento en el castillo de Huelva [el Castillo de San Pedro], en 1599, fue comprar en Portugal cuatro halcones" 34 .

Sabemos también que era aficionado a los equinos, ya que según distintas fuentes históricas, y no sólo el Elogio de Espinosa, cuando el príncipe de Gales estuvo en Madrid en busca de novia, en marzo de 1623, el conde le envió de regalo desde Sanlúcar veinticuatro caballos andaluces, enjaezados de pies a cabeza, magnificencia que por lo visto dejó "pasmada" a la comitiva inglesa ${ }^{35}$.

Por último, como vienen insistiendo Wickersham Crawford ${ }^{36}$, Jammes $^{37}$, Garrote Bernal ${ }^{38}$, Ponce Cárdenas ${ }^{39}$ y sobre todo Mira Toscano y

32 Vicent Mariner d'Alagó o de Alagón, Gvsmaneidos Libri Qvinque (h. 1631), p. 399, vv. 323-324. Cito por la tesis doctoral inédita de Francisco Bravo de Laguna, Estudio, edición y traducción del libro los Gvsmaneidos Libri Qvinque de Vicente Mariner, Las Palmas de Gran Canaria, Universidad de Las Palmas de Gran Canarias, 2002: "Praefectus regis tunc, venatoribus ipsis, / ipse fuit sylvisque suos dedit ipse favores" (p. 399, vv. 323-324). Ver al respecto Pedro Conde Parrado, "Literatura panegírica dedicada al VIII duque de Medina Sidonia: del Elogio de Pedro Espinosa a los Gusmaneidos Libri de Vicente Mariner", Criticón, 132 (2018), pp. 141-154. El autor demuestra de manera concluyente que el "Alfonso" ('listo por su nobleza') aludido en el panegírico no es el conde-duque de Olivares, como cree Bravo de Laguna, sino el conde de Niebla, "el gran hombre / que eleva hasta el firmamento los orígenes de los Guzmanes, / que llena con sus propias gestas todos los rincones del mundo” (p. 387 , vv. 14-16).

33 Luis de Góngora, Fábula de Polifemo y Galatea, en $O C$, I, núm. 255, v. 8.

34 Lara Ródenas, op. cit., p. 318.

35 Espinosa, op. cit., pp. 297-307 (p. 307).

36 James Pyle Wickersham Crawford, "The Setting of Góngora's Las Soledades", Hispanic Review, 7, 4 (1939): "The scene, I think, of the Soledades is Ayamonte and the adjacent region" (pp. 347-349 [p. 347]).

37 Robert Jammes, "Introducción", pp. 65-73, con fotografía de las marismas de los ríos Tinto y Odiel.

38 Garrote Bernal, op. cit.: "Un espacio — Gibraleón, Ayamonte- que dentro de poco recorrerá el errante peregrino de Góngora” (pp. 148-149).

39 Ponce Cárdenas, "Góngora y el conde de Niebla”, pp. 115, 123-124 y 133, si bien advierte que "parecería erróneo tratar de recorrer sus versos [de Góngora] bajo la óptica de un verismo topográfico [cursivas en el original]" (p. 119). 
Villegas Martín ${ }^{40}$, algunos elementos del paisaje de la segunda Soledad recuerdan a la costa onubense, si bien los únicos topónimos que menciona el poema son "Cartago" (Sol. 2, v. 293), "la remota Cambaya" (Sol. 2, v. 373), "desde la Mauritania a la Noruega" (Sol. 2, v. 738), "los campos tal vez de Meliona” (Sol. 2, v. 765) en Orán, "el Caístro” (Sol. 2, v. 525) en Turquía, "el Meandro" (Sol. 2, v. 526) al sur de Izmir y los horrores del "Nilo" (Sol. 2, v. 830), todo ello mezclado con los ríos "Guadalete" (Sol. 2, v. 727) y "Betis" (Sol. 2, vv. 813 y 857). En otras palabras, una geografía disparatada y exótica que de ninguna manera quiere verse confinada al paso de ganados de la isla de Barronalejo ${ }^{41}$. ¿Qué lugar? Cualquier lugar con tal de que sea "remoto" e inspire, dice Góngora, un "mudo horror divino" (OC, I, núm. 290, v. 1). Un lucus ${ }^{42}$, el bosque sagrado de Virgilio (Eneida, lib. 8, vv. 342-354), Vitruvio (Los diez libros de Arquitectura, lib. 7, cap. 5), Sannazaro (Arcadia, Prosa X) y la gráfica de ermitaños flamenca, en particular la Soledad o la vida de los padres ermitaños de Johan y Raphael Sadeler y Adriaen Collaert ${ }^{43}$.

40 Mira Toscano y Villegas Martín, op. cit., pp. 338-345.

41 Mira Toscano y Villegas Martín, ibidem: "Ya algún estudioso del tema propuso identificar esta isla con la de la Canela, aunque los versos parecen evocar más bien una isla de proporciones algo menores, probablemente rodeada por las aguas en la pleamar, pero no enteramente separada de la orilla al bajar la marea. Podríamos ejemplificar esta cambiante situación en islas como la ya citada del Barronalejo, que en bajamar permitía el paso de ganados desde San Miguel de Arca de Buey 'a pie enxuto"” (p. 339).

42 Sobre el lucus, ver John Scheid, “Lucus, nemus. Qu'est-ce qu'un bois sacré?”, en Les bois sacrés. Actes du colloque international de Naples, eds. Olivier de Cazanove y John Scheid, Nápoles, Publications du Centre Jean Bérard, 1993, pp. 13-20; y Hervé Brunon, "Locus secretus: topique et topophile", en Petrarca e i suoi luoghi. Spazi reali e paesaggi poetici alle origini del moderno senso della natura, eds. Domenico Luciani y Monique Mosser, Trévise, Fondazione Benetton Studi Ricerche, 2009, pp. 4155. Fray Hortensio Paravicino también llama al poema por su nombre correcto: lucus, bosque sagrado. Ver su "Romance describiendo la noche y el día, dirigido a don Luis de Góngora”, en Obras póstumas, divinas y humanas. Poesías completas, eds. Francisco Javier Sedeño Rodríguez y José Miguel Serrano de la Torre, Málaga, Universidad de Málaga, 2002: "Cuyas sacras Soledades, / misteriosas si no mudas" (núm. 6, vv. 113-114). Soledades sagradas, misteriosas y silenciosas: un lucus o un locus secretus que inspira un mudo horror divino.

43 Ver al respecto Francisco Javier Escobar Borrego, “¿Topografía o topotesia en el entorno espiritual del conde de Niebla? Sobre Soledades contemplativas y el Retrato de 
En contra están las dudas que inspira el testimonio de Espinosa, cuya "historia" del conde, puesta en entredicho por Morovelli ("vi a V. E. [el conde de Niebla] muy bien retratado, pero no sé si está tan bien historiado en los escritos de algunos") ${ }^{44}$ y por el propio Jammes ("es difícil, desde luego, confiar totalmente en las afirmaciones de Espinosa, constantemente preocupado por divinizar al duque de Medinasidonia”) ${ }^{45}$ está plagada de exageraciones, mentiras, inexactitudes y plagios. El conde no se refugió en Huelva porque hubiese leído Menosprecio de corte y alaban$z a$ de aldea de Guevara, como quiso hacernos creer Espinosa ("la corte, donde toda vida es corta" ${ }^{46}$; antes bien "se sobreentiende un conflicto con su suegro, o incluso puede atisbarse una tensión entre consuegros" ${ }^{47}$. Aunque es verdad que ejerció un modesto mecenazgo artístico ${ }^{48}$, no hay

Pedro Espinosa (con dos documentos inéditos)", disponible en https://e-spania.revues. org/25264; del mismo autor "Restitutio eremitica uite et studia diuinitatis. Nuevos datos sobre Pedro Espinosa y el conde de Niebla (con Góngora y la estela de la poesía culta in margine)", en L'Exemplum virgilien et l'Académie napolitaine à la Renaissance. Itinera Parthenopea, I, eds. Marc Deramaix y Giuseppe Germano, París, Classiques Garnier, 2018, pp. 399-418; y Humberto Huergo Cardoso, "De una encina embebido en lo cóncavo'. Las Soledades y la iconografía eremítica”, Creneida, 7 (2019), pp. 121-167.

44 Francisco Morovelli de Puebla, Breve discurso, dedicado al excelentísimo señor don Manuel Alonso Pérez de Guzmán el Bueno, octavo duque de Medina Sidonia (s. 1., s. 1., s. f.). Y todavía añade: "Que para saber esto [para saber historiar] como se debe son menester grandes estudios, con mucho conocimiento de los autores de la antigüedad, mucha noticia de las buenas letras, y ésta no la dan las obras de don Luis de Góngora ni sus Soledades, porque es quedarse muy con ellas". Apud Francisco Rodríguez Marín, Pedro Espinosa. Estudio biográfico, bibliográfico y crítico, Madrid, Tipografía de la Revista de Archivos, 1907, p. 293; y Carreira, "Pedro Espinosa y Góngora”, p. 172.

45 Jammes, La obra poética, p. 235.

46 Espinosa, Obra en prosa, p. 249.

47 Lara Ródenas, op. cit., p. 305.

48 Su aportación más destacada en este sentido quizá haya sido el encargo que le hizo a Juan de Roelas en el año 1619 (después de las Soledades, entonces) de nueve lienzos para el retablo mayor de la iglesia del Convento de Nuestra Seńora de la Merced, en Sanlúcar de Barrameda. Ver al respecto Enrique Valdivieso González, "Pinturas de Juan de Roelas para el convento de La Merced de San Lúcar de Barrameda”, Boletín del Seminario de Estudios de Arte y Arqueología, 44 (1978), pp. 293-302. Su padre, el VII duque de Medina Sidonia, poseía una colección mediocre de pintura mayormente religiosa. Las únicas obras con nombre de autor pertenecen a un tal Diego Pérez Mejía. En 1602 se añadieron a la colección doce cuadros de emperadores de Mateo Martínez. 
prueba documental alguna de que poseyera "espléndidos originales del Basano, Carducho, Ticiano, Rafael, Tintoreto, Parmesano [Parmigianino], Zúcaro y Barocio" ${ }^{49}$. La heroica batalla contra "una galeota de valientes piratas turcos" no ocurrió en $1599^{50}$, sino en 1601, y según Lara Ródenas, "la mayor parte de lo que se cuenta es una construcción panegírica sin más" ${ }^{1}$. Carreira recuerda "una proeza similar atribuida mucho antes a don Juan de Austria" 52 , y Lara Ródenas se pregunta si algunos de los detalles no serán un plagio del capítulo VIII de la primera parte del Quijote $^{53}$. Los plagios de Góngora en particular son numerosísimos a lo largo de toda su obra ${ }^{54}$. ¿Se inspira realmente el retrato de las Soledades en el conde de Niebla o sólo se parece al retrato del Polifemo y Espinosa infiere que son la misma persona? Salvo la palabra de Espinosa, no hay prueba documental de que Góngora haya estado en "la soledad de Huelva" 55 ; y de haberlo hecho, que tampoco es imposible, Espinosa no pudo haber sido testigo presencial del encuentro porque no entró al servicio de la casa ducal hasta julio de 1615, es decir, después de la redacción de la mayor parte de las Soledades y ocho años después - 1607- de la estancia de Góngora en Lepe y Ayamonte ${ }^{56}$. ¿Se lo contaron o lo inventó él mismo para congraciarse con su mecenas? No sería la primera vez que interpela al conde ("déjate hallar de rústica Flora") repitiendo verbatim las palabras

Ver al respecto Fernando Cruz Isidoro, "La colección pictórica del palacio sanluqueño de la Casa ducal de Medina Sidonia entre los años de 1588 y 1754", Laboratorio de Arte, 16 (2003), pp. 151-169. Como digo, nada que indique que el conde fuera un verdadero cognoscente o que poseyera obras italianas de importancia.

49 Espinosa, Obra en prosa, p. 244.

50 Ibidem, p. 265.

51 Lara Ródenas, op. cit., p. 312.

52 Carreira, "Pedro Espinosa y Góngora, p. 173.

53 Lara Ródenas, op. cit., p. 312.

54 Ver Carreira, "Pedro Espinosa y Góngora, pp. 174-179, que recoge decenas de ejemplos.

55 Espinosa, Obra en prosa, p. 265.

56 Francisco López Estrada: "Por algún motivo don Manuel Alonso Pérez de Guzmán, conde de Niebla y luego duque de Medina Sidonia, entró en 1615 en relación con el vocacionalmente ermitaño y ya presbítero de Antequera y Archidona [Espinosa]", en Obra en prosa, pp. 20-21. La estancia en Lepe y Ayamonte en el ańo 1607 es un hecho conocido. Manuel José de Lara Ródenas opina que "lo normal es que fuera al castillo de Huelva" (op. cit., p. 318), si bien el viaje no está documentado. 
de Góngora ("déjate un rato hallar del pie acertado") (Dedicatoria, vv. 2330), en este caso, la dedicatoria al duque de Béjar.

Así las cosas, prefiero no pronunciarme ni a favor ni en contra. La palabra de Espinosa no es de ninguna manera un juicio definitivo. No creo que el parecido sea evidente, pero tampoco es impensable. ¿El retrato ecuestre de las Soledades un panegírico del XI conde de Niebla? Podría ser...

De todos modos, "¿quién es el malo?" no es la pregunta que yo me haría. La cuestión palpitante es más bien: suponiendo que los versos de las Soledades fuesen un criptorretrato del conde de Niebla, ¿¿de qué tipo es? Y aquí sí que la respuesta no admite dudas: un retrato francamente manierista, de una delicadeza extrema, que tiene poco que ver con la retórica machista, belicista y patriotera del género del retrato ecuestre en cualquiera de sus manifestaciones - literaria, pictórica o escultórica-, comprendidos el Elogio al retrato del propio Espinosa ("muerde con soberbia el oro, / que aun en él mana el tesoro / de la mano que lo enfrena"), aunque no hay rastro del tal "retrato" 57 ; el retrato ecuestre de Carrillo y Sotomayor ("con pecho más fuerte", "con fiera vista y encendida", "de enojo y de diamante armado"), ${ }^{58}$ y los rimbombantes Gusmaneidos libri quinque de Vincent Mariner ("más grande que Hércules trilla las regiones de la tierra con las armas, / esparciendo, con la fortaleza del pueblo, el poder bélico, / y debilitando al mismísimo Marte con la punta del hierro") ${ }^{59}$. Hércules aparte, "muerde con soberbia el oro [...] que lo enfrena", como dice Espinosa, no es lo mismo que aquel "colérico mordía / el oro que süave lo enfrenaba” de Góngora. El plagio es evidente, pero Espinosa se ha cuidado de omitir una voz que Góngora repite dos veces (Sol. 2, vv. 808 y 817 ) en menos de diez versos: suave. ¿A qué se debe la omisión? ${ }^{60}$

57 Espinosa, op. cit., p. 246.

58 Luis Carrillo y Sotomayor, "Égloga primera”, en Obras, ed. Rosa Navarro Durán, Madrid, Castalia, 1990, pp. 217-229 (pp. 217-218, vv. 10, 18 y 19).

59 Mariner, op. cit:: "Terranum tractus armis terit Hercule maior / bellica diffundens populi per robora iura / atque ipsum Martem contundens cuspide ferri” (p. 392, vv. 142-144).

60 Todo el retrato ecuestre de Espinosa incluido en el poema "Panegírico", desde el verso "Da el caballo testimonio" hasta "la voz en el instrumento" (Obra en prosa, pp. 244-247 [pp. 246-247, vv. 31-50]), se inspira en el de las Soledades, si bien la imagen que emerge del conde en ambos textos, si el poema de Góngora se refiriese al conde, es radicalmente diferente. En pocas palabras, donde Góngora escribe "suave", Espinosa entiende "hundes la tierra" (v. 33), "a imperio se ordena" (v. 36), 


\section{Si EN Miembros No ROBUSTO}

"Viva imagen de la guerra" ${ }^{61}$, o, más claro todavía, "viva imitación de la dureza de las armas y de la guerra" ${ }^{2}$, la caza es por definición un ejercicio robusto para hombres varoniles y fornidos, la viva "academia de Hércules"63. Según Núñez de Avendaño en sus Avisos de cazadores y de caza (1543), el nombre mismo "cazador" "es arábigo; quiere decir en lengua castellana subjectador, e ansí los arábigos suelen llamar a los señores que tienen subjection sobre hombres cacies, que quiere decir subjectadores, y de ahí se derivó este nombre, caza, que quiere decir subjecta" ${ }^{64}$. No es así (cazar no viene del árabe cacies, sino del latín vulgar captiare, derivado de capere o 'coger'), pero de todos modos la falsa etimología refleja correctamente el sentir de la época: "Los cazadores muy convenientemente se

"huella con desdén" (v. 37); y donde Góngora desata ("desatada / majestad"), Espinosa encierra, ciñe y ata: "del valor que en ti se encierra" (v. 32), "tu frente ciñe contento, / y, atando en dulzura al viento" (vv. 46-47). Aun si se tratara del mismo modelo, que no es nada evidente, son dos poéticas opuestas, una suave y la otra dura. Reproducido igualmente en Pedro Espinosa, Poesía, ed. Pedro Ruiz Pérez, Madrid, Castalia, 2011, pp. 257-260 (p. 259, vv. 31-50).

61 Juan Mateos, "Al lector", en Origen y dignidad de la caza, Madrid, Francisco Martínez, 1634, s. p. El original incluye un retrato ecuestre del Conde-Duque. Idéntica frase en Fernando Tamariz de la Escalera, "Al lector", Tratado de la caza al vuelo (1654), Sevilla, Imprenta de E. Rasco, 1889: "La dignidad de este noble ejercicio se conoce fácilmente, por ser propia acción de reyes y príncipes, y el maestro más docto que puede enseñar mejor el arte militar teórica y prácticamente. Los bosques son las escuelas, los enemigos las fieras, y así con razón es llamada la caza 'viva imagen de la guerra'. Y Julio Pólux afirma que los cazadores usaban del mismo traje que los soldados" (p. 10).

62 Alonso Martínez de Escobar, "El autor, a todos", en Arte de ballestería y montería, Madrid, Imprenta Real, 1644, s. p.

63 Mateos, op. cit., s. p.

64 Pedro Núñez de Avendaño, Aviso de cazadores y de caza, Alcalá de Henares, Joan de Brocar, 1543, f. 1r-1v. El propósito del libro es refutar las ideas del "vulgo ignorante"; a saber, "que ocupados los señores en cazar, fallescen algo en la gobernación de sus vasallos"; "que los gastos de la caza son muchos, y querríen que los señores no fuesen pródigos en esto"; y finalmente "que la caza y animales que los señores tienen en sus bosques y dehesas destruyen las heredades y términos y hacen otros daño" (todas las citas en el prólogo sin foliar). Está claro, pues, que era un deporte contestado desde todos los puntos de vista: político, económico y ecológico. 
dicen subjectadores porque a modo de guerra subjectan las aves y bestias fieras, y en lengua latina se llaman venatores y la caza de estos se llama opresiva, y tuvo principio donde Nemroth edificador en Babilonia, el cual la Sagrada Scriptura llama robustos venator ['cazador robusto']"65. En efecto, la Vulgata dice: "Y fue [Nemrod] robusto cazador [robustus venator] delante del Señor. Por lo cual salió el proverbio: 'Robusto cazador [robustus venator] delante del Señor, como Nemrod"'66. Y como era un proverbio, un prejuicio compartido, encontramos el mismo epíteto - robusto- en las Notas al panegírico del señor marqués de Montalbán (1651) de Trillo y Figueroa: "El concepto a que miran esas cazas es [...] a solicitar al marqués robusto, ejercitado y lejos de las delicias femeniles" ${ }^{67}$; en el retrato de Fernando el Católico (1631) de Saavedra Fajardo: “¿Quién viendo a vuestra majestad tan brioso y diestro en la plaza, y tan robusto en los ejercicios de la caza, no le pusiera en las manos el cetro que le da su augusta y real sangre?" ${ }^{8}$; en el Canto a Jacob y Raquel del príncipe de Esquilache: "Volvió del campo el cazador robusto / y el logro de sus manos le presente" ${ }^{69}$; y en El Actéon de Enrique Vaca de Alfaro: "Viéndose fatigado, / este robusto cazador dispone"70. Lupercio de Argensola también lo emplea:

65 Núñez de Avendaño, ibidem, f. 1v.

66 "Erat robustus venator coram Domino. Ob hoc coram proverbium: Quasi Nemrod robustus venator coram Domino". Cito por la edición de Felipe Scio de San Miguel, La Biblia Vulgata latina, traducida al español, tercera ed., Madrid, Ibarra, 1818, t. 1, Génesis 10: 8-9.

67 Francisco de Trillo y Figueroa, Obras, ed. Antonio Gallego Morell, Madrid, CSIC, 1951, p. 368. En el mismo texto: "Porque ha de ser venerado [el marqués], inclinándole al ejercicio de la caza, imitando su dureza y escabrosidad en Virgilio, libro 8, Aeneis, donde: 'Horrida praecipue cui gens adsuetaque multo / uenatu nemorum, duris Aequicula glaebis'. Ejercicio robusto le llamaron Cicerón, lib. 2, De natura deorum; Julio Pólux, lib. 5; Jenofonte, Ciropedia, lib. 8 y otros" (p. 367). Y más adelante: "Comienzo por la caza del jabalí por ser la más ordinaria y robusta de Andalucía” (p. 367).

68 Diego de Saavedra Fajardo, Razón de Estado del rey católico don Fernando (1631), en Rariora et minora, ed. José Luis Villacañas Berlanga, Murcia, Tres Fronteras, 2008, pp. 183-205 (p. 188).

69 Francisco de Borja y Aragón, príncipe de Esquilache, Obras en verso, Madrid, Diego Díaz de la Carrera, 1648, p. 73. Ver igualmente el poema Antonio y Cleopatra: "Del alto monte la robusta caza" (p. 124).

70 Enrique Vaca de Alfaro, El Acteón, en María Ángeles Garrido Berlanga, La obra 
Deja el lecho caliente con la esposa dormida el cazador solícito y robusto;

sufre el cierzo inclemente, la nieve endurecida, y tiene de su afán por premio justo interrumpir el gusto y la paz de las fieras, en vano fuertes, cautas y ligeras ${ }^{71}$.

Es más, "augusto” rima normalmente con "robusto”. Así, por ejemplo, en las "Exequias del rey nuestro señor don Felipe II" (1598) del propio Lupercio de Argensola: "Como Augusto. / Ese brazo robusto"72; en el Retrato panegírico del serenísimo señor Carlos de Austria (1633) de Bocángel: "Con ojos de diamante y sed robusta / bebiendo llama de la frente augusta"73; en El Fernando o Templo de su fama (1637), también de Bocángel: "Del antes real como después augusto / Héctor novel del Húngaro cuñado / se mezcla al suyo campo tan robusto"74; y en la Jerusalén conquistada (1609) de Lope:

poética de Enrique Vaca de Alfaro: edición y estudio de la Lira de Melpómene, tesis doctoral, Sevilla, Universidad de Sevilla, 2016, pp. 424-464 (p. 428, vv. 55-56). La tesis ha sido publicada con el título de Edición y estudio de la Lira de Melpómene de Enrique Vaca de Alfaro, Córdoba, UCOPress, 2018.

71 Lupercio Leonardo de Argensola, "Alivia sus fatigas", en Flores de poetas de Juan Antonio Calderón (1611). Transcripción del manuscrito llamado Segunda parte de las Flores de poetas ilustres de España, eds. Jesús M. Morata y Juan de Dios Luque, Granada, Granada Lingüística, 2009, pp. 282-283 (p. 282, vv. 19-27). Compárese con Bartolomé Leonardo de Argensola, Rimas, ed. José Manuel Blecua, 2 tomos, Madrid, Espasa-Calpe, 1974: "Donde Adonis atiende / a la robusta caza" (Canción a la primavera, t. 1, 1, vv. 26-27); "ya el robusto ejercicio de la caza" (A don Fernando de Borja, virrey de Aragón, t. 1, 44, v. 238).

72 Argensola, ibidem, t. 2, 167, vv. 69-70.

73 Gabriel Bocángel, Retrato panegírico del serenisimo señor Carlos de Austria, en Obras completas, ed. Trevor J. Dadson, 2 tomos, Madrid, Iberoamericana, 2000, t. 1, pp. 325-386 (p. 376, estrofa CXVIII, vv. 943-944).

74 Gabriel Bocángel, El Fernando o Templo de su Fama, ibidem, pp. 397-410 (p. 405, estrofa XXV, vv. 159-161). 
Salió arrogante a la campaña Agusto,

mozo más temerario que robusto,

en un caballo blanco... ${ }^{75}$.

¿Por qué afirma Góngora lo contrario?: "En sangre claro y en persona augusto, / si en miembros no robusto, / príncipe les sucede". ¿Acaso no sabía todo el mundo que "los grandes príncipes deben ejercitar la caza como cosa muy saludable y necesaria, de donde el cuerpo se hace más robusto y el ánimo más fuerte ejercitando en ella todas las cosas de la guerra, así correr a caballo como a pie, saltar, luchar, tomar los animales feroces, acometellos, conquistallos, vencellos, sufrir el calor del estío y el frío del ivierno, la hambre y la sed, dormir en piedras y asperezas sin regalo"? ${ }^{76}$

\section{LA EDAD DE LA ADOLESCENCIA}

$\mathrm{Al}$ menos tres respuestas son posibles. La primera es la que ofrece Serrano de Paz en sus olvidados Comentarios a las Soledades: "Seguía toda la chusma dicha un príncipe ilustre en sangre, augusto en su persona, aunque no de mucha edad'77. Y aclara todavía:

75 Félix Lope de Vega y Carpio, Obras completas. Poesía, III. Jerusalén conquistada. Epopeya trágica, ed. Antonio Carreño, Madrid, Fundación José Antonio de Castro, 2003, lib. 10, vv. 129-134. La misma consonancia en el libro 7: "Hicieron Saladino al más robusto, / más atrevido y de color trigueño; / otro a Branzardo y otro al siempre augusto / Ricardo inglés" (vv. 13-17). El tema se vuelve obsesivo en Lope: "Era robusto Candelor, fornido / descubierto de músculos y venas" (lib. 1, vv. 112-113); "las armas del robusto al más robusto" (lib. 10, v. 91); "Suero, Tello, Fortún, Tirso, Haro, Bustos, / todos de igual valor, todos robustos" (lib. 12, vv. 131-132); "el conde igual a Encelado robusto" (lib. 3, v. 77), etc.

76 Luis Barahona de Soto, Diálogos de la montería, prólogo Francisco R. de Uhagón, Madrid, s. 1., 1890, lib. 1, pp. 11-12. No he podido consultar la edición moderna del texto a cargo José Lara Garrido y Antonio M. Fernández, Málaga, Asociación para el Desarrollo Rural de la Comarca Nororiental de Málaga, 2002. Otros ejemplos en Juan Matas Caballero, 'Un 'espantoso rumor' de 'tremenda batalla' entre Góngora y el duque de Béjar”, en El mecenazgo literario, pp. 43-74 (pp. 44-56).

77 Manuel Serrano de Paz, Comentarios a las Soledades, Madrid, Biblioteca de la Real Academia de la Lengua, mss. 114-115, t. 2, f. 496r. 
Era el príncipe no robusto en miembros, esto es, aun estaba en la edad de la adolescencia, que los miembros no tenían todo lo robusto que tenían de ser, edad propia para la caza y la que más la apetece, y por eso notada del poeta ${ }^{78}$.

No robusto, entonces, por ser joven y no haber alcanzado todavía la edad viril. "Augusto, robusto de edad", llama Tácito al emperador César Augusto $^{79}$, si bien en la época no era raro presentarlo joven (Fig. 2). Es una hipótesis sumamente plausible que cuenta con el apoyo de seis ejemplos más en las propias Soledades, no digo ya fuera de ellas ("edad floreciente" "en tierna edad dichoso" "11, "la edad dichosa"82, "florida edad"83, etc.): el peregrino mismo ("si no augusto, esclarecido, / el joven" 84 , "desnudo el joven", etc.) ${ }^{85}$, la novia de la Soledad primera ("niño amó la que adora adolescente, / villana Psiques") ${ }^{86}$, los villanos de la misma Soledad primera (“arrogante joven llama”), ${ }^{87}$ los jóvenes pescadores Lícidas y Micón ("en redes ambos y en edad iguales") ${ }^{88}$, es decir, como glosa Díaz de Rivas, "mancebos de una edad" 89 , "la edad tierna de un pescador" patriarca de la segunda Soledad (“joven ya gallardo”) 91 y el séquito de cazadores (“el hombre a un joven cela”) ${ }^{92}$. En efecto, los personajes de Góngo-

78 Ibidem, t. 2, f. 498r.

79 Cornelio Tácito, Obras de Caio Cornelio Tácito, Dovay, Marcos Wyon, 1629: "Augusto, robusto de edad, sostuvo a sí mismo, a su casa y a la paz" (lib. 1, p. 5). Ver, no obstante, la nota 310 .

80 Góngora, $O C$, I, núm. 103, v. 2.

81 Ibidem, I, núm. 154, v. 6.

82 Ibidem, I, núm. 289, v. 8.

83 Ibidem, I, núm. 179, vv. 1-2.

84 Góngora, Sol. 1, v. 733-734.

85 Ibidem, v. 34.

86 Ibidem, vv. 773-774.

87 Ibidem, v. 982.

88 Góngora, Sol. 2, v. 518.

89 Pedro Díaz de Rivas, Anotaciones a la Segunda Soledad, ed. digital Melchora Romanos y Patricia Festini, anotación 87. Disponible en Proyecto Pólemos, http://obvil. sorbonne-universite.fr/corpus/gongora/1617_soledad-segunda-diaz.

90 Ibidem, anotación 96.

91 Góngora, Sol. 2, v. 264.

92 Ibidem, v. 794. 
ra se reparten en dos grupos de edad diametralmente opuestos: la edad de la confianza $(O C, \mathrm{I}$, núm. 26, v. 6) y la edad del desengaño $(O C, \mathrm{I}$, núm. 26 , v. 54; 133, v. 7, etc.), la "edad menos que tierna” ( $O C$, I, núm. 102, v. 34) y la "edad más endurecida" (OC, I, núm. 102, v. 36), la "segunda edad" de la novia (Sol. 1, v. 776) y el "a pesar de mi edad" del viejo pescador (Sol. 2, v. 396). O se engañan y todavía no saben que van a morir, como los traviesos conejuelos de la segunda Soledad ${ }^{3}$, o ya lo saben y esperan la muerte con estoica resignación.

El príncipe de las Soledades está todavía en la edad de la confianza: "poca edad, mucha belleza" (OC, I, núm. 454, v. 14), "generoso ['noble'] mancebo / purpúreo ['rosado'] en la edad” (OC, I, núm. 416, vv. 1-2); no tiene todavía "la fuerza de la edad" (OC, I, núm. 317, v. 199). Aunque si es así, la efigie no cuadra con la persona del XI conde de Niebla (1579-1636), que para la fecha de redacción de las Soledades, pongamos hacia 1614, tendría unos treinta y cinco años: todo un hombre hecho y derecho, como Doricleo en El peregrino en su patria ("Tendrá ahora cuarenta y uno. Está fuerte, robusto, gallardo, porque la misma experiencia de la vida le ha fortalecido los miembros") ${ }^{94}$; o Roque Guinart en la segunda parte del Quijote ("mostró ser de hasta edad de treinta y cuatro años, robusto" $)^{95}$. ¿Debemos pensar que se trata del retrato obsoleto de un conde de Niebla que en el 1614 ya no existía? ¿El retrato de un conde de Niebla débil y enfermizo, como insinúa Lara Ródenas? ${ }^{36}$ ¿Y por qué haría

93 Góngora: "Salieron [los conejuelos] retozando a pisar flores, / el más tímido al fin más ignorante / del plomo fulminante" (Sol. 2, vv. 280-282). El más precavido de todos los conejos es el más ignorante de la muerte que le espera.

94 Félix Lope de Vega y Carpio, El peregrino en su patria, ed. Julián González-Barrera, Madrid, Cátedra, 2016, lib. 1, p. 155. En el mismo libro describe a un conde de Niebla todavía veinteañero de la siguiente manera: "Famosos hombres nuestros siglos tienen / en todas profesiones y ejercicios. / [...] / los tiernos años del famoso conde / de Niebla, luz de España, el mundo admira" (lib. 4, pp. 523-524). Los "tiernos años" del conde de Niebla en torno a los años 1602-1603 cuando se redactó $E l$ peregrino en su patria, publicado en 1604 , no hacia 1614 cuando se escribió la segunda Soledad. Sobre el parentesco entre El peregrino en su padria y las Soledades, ver Marcella Trambaioli, "El peregrino de amor en Lope y Góngora: entre competición literaria y mecenazgo", en El duque de Medina Sidonia, pp. 203-228.

95 Miguel de Cervantes, Don Quijote de la Mancha, ed. Martín de Riquer, Barcelona, Editorial Juventud, 1955, t. 2, segunda parte, cap. 60, p. 975.

96 "Acababa de cumplir 20 años [en 1599] y aún podía parecer más joven, pues, como 
Góngora tal cosa? ¿Acaso así se aseguraría el favor del conde? Y aunque así fuera, ¿no decía el propio Góngora en la dedicatoria del Polifemo que la caza era "ejercicio robusto"?
Ahora que de tuz tu Niebla doras, escucha, al son de la zampoña mía, si ya los muros no te ven de Huelva peinar el viento, fatigar la selva. [...]
Treguas al ejercicio sean robusto ocio atento, silencio dulce, en cuanto debajo escuchas, de dosel augusto ${ }^{97}$.

¿Qué ha cambiado entre el Polifemo y las Soledades para que, además de perder el nombre (Niebla) y la patria (los muros de Huelva), el mismo conde de Niebla sea "augusto" y "robusto" en un poema ("llama ejercicio robusto la caza porque hace robustos a los que se ejercitan en ella, y como es imagen de la guerra, se acordó de treguas, que es la paz", recalca Salcedo Coronel) ${ }^{98}$, y "augusto" y "no robusto" en el otro??9

escribió Góngora en la Soledad segunda, era 'en miembros no robusto’. Además de enfermizo, de lo que dio continuas muestras a lo largo de los ańos, señala Rodríguez Marín que 'era el conde de Niebla de constitución endeble y de carácter melancólico"' (Lara Ródenas op. cit., p. 307).

97 Góngora, Fábula de Polifemo y Galatea, OC, I, núm. 255, vv. 5-19.

98 García de Salcedo Coronel, El Polifemo de don Luis de Góngora comentado (1629), ed. facsimilar, Madrid, Extramuros, 2008, f. 7r.

99 La pérdida del nombre ha intentado explicarla Ly en el ya citado "De sublimes y modestas cumbres: la figura del conde de Niebla en la segunda Soledad". Su tesis es que aunque, en efecto, el texto no mienta el nombre del conde, alude a él a través del anagrama "neblî" en los versos "el Neblí que, relámpago su pluma, / rayo su garra, su ignorado nido / o lo esconde el Olimpo, o densa es nube" (Sol. 2, vv. 745-747). Podría ser, pero si es así, ¿̇no sería un anagrama también, y con más razón todavía, el verbo esconde en el sintagma "lo esconde el Olimpo"? El Neblí es conde. Inmediatamente advertimos el peligro: ¿dónde termina el juego anagramático? Puestos a buscar anagramas, es fácil encontrarlos: "CuaNDO sube" (Sol. 2, v. 748), "dONDE I entre las conchas hoy del SUR ESCONDE” (Sol. 2, vv. 773-774) (el conde se escondió en el suroeste, en Huelva), "o la alta basa que el OCEANO muerte" (el conde de Niebla era Capitán General del Mar Océano), etc. También lee el pasaje en busca de anagramas Carroll B. Johnson, "On the Beach: Myth, Falconry, and the 
Una duda más. Como es sabido, el conde de Niebla histórico era Cazador Mayor de Volatería (1599), Capitán General de la Costa de Andalucía (1602), Capitán General del Mar Océano (1603) y caballero de la insigne orden del Toisón de Oro $(1615)^{100}$. ¿Qué pensaría de verse comparado con un delicado efebo de complexión enfermiza? ¿No preferiría ser "de un pecho muy más robusto / y de una edad no tan tierna" (OC, I, núm. 454, vv. 23-24). ¿No andaría “corrido ['avergonzado'] en ver que le tenían / por menos fuerte y de ánimo robusto"? ${ }^{101}$ Véase si no cómo lo pinta Espinosa en el Jeroglifico y efigie del excelentísimo, invictísimo y famoso en todos siglos don Manuel Pérez de Guzmán el Bueno, Duque de Medina Sidonia, Conde de Niebla, no recogido en la edición de la Obra

End of the Soledades", Caliope, 8, 1 (2002): "If the word niebla is in fact a pun, the celebration of the Conde is severely compromised" (pp. 103-123; p. 119). Se refiere al verso "la disonante niebla de las aves" (Sol. 2, v. 894), también mencionado por Ly: "Es de notar además cómo se completa el paradigma [Niebla] / neblí / noble / nube / sube con la aparición tardía, al final del poema, del nombre común niebla (s) aplicado a la 'disonante niebla'" (p. 68). Sobre el peligro de las lecturas anagramáticas, ver Jean Starobinski, Las palabras bajo las palabras. La teoría de los anagramas de Ferdinand de Saussure, trads. Lía Varela y Patricia Willson, Barcelona, Gedisa, 2015: "Ferdinand de Saussure buscó ese testimonio [el testimonio de una lengua secreta debajo de la lengua], y no encontró nada decisivo. Silencio embarazoso, que lleva unas veces a formular la hipótesis de una tradición 'oculta”' (p. 106).

100 Rodríguez Marín, op. cit., p. 232; y López Estrada (ed.), op. cit., p. 23.

101 Félix Lope de Vega y Carpio, Jerusalén conquistada, lib. 15, vv. 79-80. Compárese con Garcerán, "que preciado de robusto / despreciaba de amor el tierno afecto" (lib. 13, estrofa 37). Más reveladoras todavía son las palabras de Ismenia: "Venus con Marte fue la estrella mía: / mi verde edad, mis años juveniles / no son capaces del robusto brío / que muestra agora afeminado el mío" (lib. 13, estrofa 74). Como Ismenia, el príncipe de las Soledades sería una mezcla indiscernible — neutral— de Venus y Marte. Ver igualmente el "jinete niño" (lib. 3, estrofa 27) de Bernardo de Balbuena, El Bernardo, o Victoria de Roncesvalles, ed. crítica Martín Zulaica López, Siero, Asturias, EntreAcacias, 2017: "Hijo hermoso de Venus y de Marte / en su aire le juzgaras peregrino, / y humilde de Narciso la pintura, / si, como yo, te hablara su hermosura" (lib. 3, estrofa 25). La estrofa siguiente dice: "Niño que el tierno bozo le apuntaba, / de cuerpo algo más grande que un pequeńo, / de alegres ojos y de vista brava, / süave en el mirar y zahareño. / Temor el verlo y alegría causaba, y el rostro armado de capote y ceño, / mezclando a lo hermoso lo robusto, / la cifra hacía del deleite y gusto" (lib. 3, estrofa 26). Tierno, suave y hermoso, pero aun así robusto. El poema se completó en 1609, aunque no vio la luz hasta el año 1624. 
en prosa a cargo de López Estrada:

Hase de pintar la persona del Duque armado de medio cuerpo arriba, botas y espuelas, bien plantado, tusón al cuello, su bastón de general en la mano derecha, y en la izquierda una llave como que está cerrando con ella un candado, que, pendiente de las gruesas armellas de una puerta de un muro que atraviese de banda a banda la barra de San Lúcar [en referencia a Sanlúcar de Barrameda], denote el mando y potestad que el Duque tiene en lo tocante al mar [en alusión al título de Capitán General del Mar Océano] ${ }^{102}$.

Son instrucciones detalladas de cómo se debe pintar al conde: botas y espuelas, la bengala del poder en la mano derecha, cerrar, candado, gruesas armellas, mando y potestad. Nada ni remotamente comparable a la suavidad del retrato de las Soledades.

Lo mismo digo del retrato de Carrillo y Sotomayor incluido en su Fábula de Acis y Galatea ("deleita a Marte siempre", "el feroz semblante", "el fuerte morrión", "arrojando / rayos la espada") ${ }^{103}$, bien conocida de Góngora, y del panegírico de Mariner: "Con su ley [del conde de Niebla] todo lo domeña, trilla, invade, lo oprime todo. / Pues la fortaleza de Marte está presente en tan grande corazón"104; “con estos juegos de poderosas fieras descubre [el conde de Niebla] las verdaderas batallas / que deben ser vencidas por cruel mano y el feroz Marte" ${ }^{105}$.

102 Pedro Espinosa, Obras, ed. Francisco Rodríguez Marín, Madrid, Tipografía de la Revista de Archivos, 1909, pp. 410-412 (p. 410). Aunque también lo llama "Adonis, con luciente jabalina" (Obras en prosa, p. 241), plagiando el retrato del duque de Béjar de Góngora: "La asta de tu luciente jabalina" (Dedicatoria, v. 21). Repito la pregunta: ¿Quién imita a quién? ¿Góngora al conde de Niebla o Espinosa a Góngora? Sobre el sintagma "luciente jabalina", ver Bonilla Cerezo y Tanganelli, op. cit., p. 41.

103 Carrillo y Sotomayor, op. cit., pp. 199-216 (pp. 200-201, vv. 19, 20, 25 y 33-34). La fábula está "dirigida al conde de Niebla" (p. 198), cuyo retrato abarca los primeros cuarenta y un versos. La efige, donde se destacan las glorias navales del conde ("mil remos gobernados / de fuertes brazos"), nada tiene que ver con el supuesto retrato de las Soledades.

104 Mariner, op. cit., lib. 1, p. 421, vv. 851-852. El original en latín dice: "Cuncta suo tunc iure domat, terit, occupat, arctat. / Martia nam tanto subsistit corde facultas".

105 Ibidem, lib. 1, p. 400, vv. 343-344. El original dice: "His gravium ludis manifestat vera ferarum / bella truci vincenda manu et Mavorte feroci”. 
Pedro Beltrán también reproduce el tópico del héroe marcial: “[...] sin parar / hace a los moros temblar / su valor godo [del conde de Niebla], admirando. / Advierte con la destreza / que el fuerte conde gallardo / hurta el cuerpo y la cabeza / a la cólera de un dardo"106. Conde diestro, fuerte y gallardo que hace temblar a los moros, incluso a los veintidós años.

Entonces, o el retrato de Góngora miente (nada raro en un texto panegírico, por otra parte), o no es un retrato del conde de Niebla. $\mathrm{O}$ es un retrato del conde de Niebla a contrapelo de la imagen proverbial del cazador, a saber, el bellator augusto y robusto que acaba de abandonar el lecho que calienta su mujer para enfrentarse a la nieve "endurecida" e interrumpir el gusto de las fieras "en vano fuertes". Él es más fuerte que todas las fieras y su gusto en la cama no tiene fin ${ }^{107}$.

\section{Pisa Lesbín, segundo Ganimedes}

La segunda razón tiene que ver con el decoro o la convenevolezza — "atención a la cualidad de las personas"—— ${ }^{108}$, y es que en las Soledades la ro-

106 Pedro Beltrán, La caridad guzmana (1612). Apud Rodríguez Marín, Obras de Pedro Espinosa, p. 239, n. 1. La referencia a las "heroicas hazañas" del conde cuando apenas contaba con 20 ańos se halla en la p. 238.

107 ¿Cómo explica Jammes la falta de robustez de nuestro príncipe? "Teniendo en cuenta la importancia poética de la dedicatoria — dice—, hubiera sido lógico suponer —al contrario de lo que se ha dicho en el capitulillo precedente- que el noble personaje retratado en los vv. 809-823 de la segunda Soledad era el duque de Béjar: es lo que pensaron Pellicer y Salcedo Coronel. La suposición no era nada inverosímil, porque ciertos rasgos de este retrato convendrían al duque: 'en sangre claro', 'abreviada / en modestia civil real grandeza', 'la alta mano / de cetra digna”" ("Introducción” a su edición de las Soledades, pp. 78-79). Ciertos rasgos, pero no todos; omite el verso "si en miembros no robusto" porque sabe que no convendría ni al duque de Béjar ni al conde de Niebla. Idéntica elipsis en La obra poética de don Luis de Góngora y Argote, trad. Manuel Moya, Madrid, Castalia, 1987: "Góngora ha querido insistir sobre el porte 'real' del conde de Niebla, ya duque de Medinasidonia en el momento en que escribía esos versos: 'augusto', 'príncipe', 'real grandeza', 'soberano', 'mano de cetro digna”" (p. 235, n. 87). Pero no "si en miembros no robusto", "espumosa", "ligereza", "desatada / majestad" y "süave lo enfrenaba".

108 Lodovico Dolce, Diálogo de la pintura, ed. bilingüe Santiago Arroyo Esteban, Ma- 
bustez no es un rasgo físico de la nobleza, sino exclusivamente de los villanos. De este modo, todos los serranos de la Soledad primera serían "gruesos" (Sol. 1, v. 1004), "membrudos" (Sol. 1, v. 1005) y "fuertes" (Sol. 1, v. 1005), "ágil, a pesar de lo robusto" (Sol. 1, v. 1006), "robustos luchadores" (Sol. 1, v. 965), "tanto garzón robusto" (Sol. 1, v. 663), "progenie tan robusta, que su mano / toros dome" (Sol. 1, vv. 821-22), pero no el peregrino ni el príncipe a caballo, más parecidos ambos al "garzón de Ida" - Ganimedes- (Sol. 1, v. 8), como el hijo del marqués de Ayamonte (OC, I, núm. 164), que a Atlante ("el hombro robusto / del español Atlante") ${ }^{109}$ y a Anquises ("tal del muro abrasado hombro robusto, / de Anquises, redimió, la edad dichosa") ${ }^{110}$. Dolce lo explica del siguiente modo: "En esto [en la representación de los cuerpos] es menester que se respete la conveniencia [convenevolezza] que hemos adjudicado a la invención. Puesto que si el pintor debe pintar a Sansón, no le debe atribuir la suavidad y delicadeza [morbidezza e delicatezza] de Ganimedes; y si ha de pintar a Ganimedes, debe evitar representar los nervios y la robustez [nervi e robustità] de Sansón" ${ }^{111}$. La única excepción serían los pescadores Lícidas (también comparado con Ganimedes) y Micón (comparado con Adonis), que al ser "poetas" y tener nombre helénico, ocupan un lugar intermedio entre las artes mecánicas (la pesca) y las artes del espíritu (la canción). Micón en particular era tan bello que su figura despertaba la envidia, ya no sólo de las aguas en que se reflejaba su rostro, "agua al fin dulcemente dura" (Sol. 2, v. 578), sino incluso de "los musculosos jóvenes desnudos" (Sol. 2, v. 580) que soñaban con él. De manera inverosímil, las mujeres son más robustas que los propios hombres. Así las hijas del pescador en la Soledad segunda y la propia sobrina de Góngora, Francisca de Argote: "Valor es este, señora, / y animosidad es esta / de un pecho muy más robusto / y de una edad no tan tierna" (OC, I, núm. 454, vv. 23-24), como acabo de citar. Mujer de tierna edad, pero todavía así más robusta que el príncipe de las Sole-

drid, Akal, 2010: "Comenzando por la invención, digo que en ella intervienen varios factores, de los cuales los principales son el orden y la conveniencia [convenevolezza]" (Primera parte, p. 125).

109 Góngora, "A los poetas que asistían en Ayamonte”, OC, I, núm. 256, vv. 20-21.

110 Góngora, "A Juan de Villegas, alcalde mayor de Luque", ibidem, núm. 289, vv. 7-8. 111 Dolce, op. cit., segunda parte, p. 141. 
dades. Más ambiguo todavía es el retrato de Santa Teresa: "Medio monja y medio fraile, / soror Ángel, fray Teresa, / monja ya y fraile” (OC, I, núm. 282, vv. 15-17) ${ }^{112}$. Como han visto Smith ("Gongora's presentation of women and of men seems nonstandard") 113, Amann ("reversal of gender roles") 114, Heipli ("Góngora's treatment of the Ganymede myth is unusual") 115, De Armas ("male eroticism") ${ }^{116}$ y Waissbein ("la ambigüedad 'narrativa / descriptiva' de la masculinidad y feminidad") ${ }^{117}$, cada uno a su modo y con mayor o menor fortuna, la ambigüedad sexual del poema, sin ser excepcional ${ }^{118}$, tampoco puede pasarse por alto, y ya en su tiempo levantó más de una ceja. ¿Qué necesidad tenía Pellicer, por ejemplo, de aclarar que "no afemina don Luis a Acis, aunque le pinta tan hermoso" si no fuera porque afemina a Acis? ${ }^{119}$ Díaz de

$112 \mathrm{Y}$ todavía ańade: "Dividida en dos fue entera" (OC, I, núm. 282, v. 14). Es decir, dividida en dos sexos, todavía así era una sola persona.

113 Paul Julian Smith, "Barthes, Góngora, and Non-Sense”, PMLA, 101, 1 (1986), pp. $82-93$ (p. 86).

114 Elizabeth M. Amann, "Orientalism and Transvestism: Góngora's 'Discurso contra las navegaciones' (Soledad primera)”, Caliope, 3, 1 (1997), pp. 18-34 (p. 28).

115 Daniel L. Heiple, "Góngora and the Myth of Ganymede", Lesbianism and Homosexuality in Early Modern Spain: Literature and Theater in Context, eds. María José Delgado y Alain Saint-Saëns, Nueva Orleans, University Press of the South, 2000, pp. 219-232 (p. 220). Ver igualmente Mercedes Blanco, "La introducción de un Ganimedes sin nombre: Góngora y Virgilio", en Góngora heroico. Las Soledades y la tradición épica, Madrid, Centro de Estudios Europa Hispánica, 2012, pp. 178-185.

116 Frederick A. de Armas, "Embracing Hercules / Enjoying Ganymede: The Homoerotics of Humanism in Góngora’s Soledad primera", Caliope, 8, 1 (2002), pp. 125140 (p. 127).

117 Daniel Waissbein, “El 'vario sexo' de Polifemo”, en El universo de Góngora: orígenes, textos y representaciones, ed. Joaquín Roses, Córdoba, Diputación de Córdoba, 2014, pp. 177-214 (p. 188).

118 Ver, por ejemplo, María de Zayas, Desengaños amorosos, ed. Alicia Yllera, Madrid, Cátedra, 1993: "Pareciéndole al traidor que luchaba con un gigante, y a Beatriz, que sus fuerzas en aquel punto no eran de flaca mujer, sino de robusto y fuerte varón" ("Desengaño noveno", p. 445). Recuérdese igualmente la peregrina disfrazada de hombre de $E l$ peregrino en su patria de Lope: "Ya la vergüenza había hecho en su rostro y el ánimo de defenderse en su pecho colores y fuerzas: con las unas [las colores, femenino en la época] estaba singularmente hermosa, con las otras [las fuerzas] atrevidamente robusta" (p. 156).

119 Remito al estudio de Waissbein, op. cit., quien no cita la frase de Pellicer que refuerza aún más su argumento. 
Rivas es todavía más explícito: "Parece peca el poeta [Góngora] contra los preceptos del arte, introduciendo a estas pescadoras que tiran dardos valientes, hieren peces marinos fieros, los cuales parecen actos de ánimo virily robusto, por lo cual dijo Aristóteles que el poeta ha de pintar flacas a las mujeres" ${ }^{120}$. No olvidemos tampoco los incisos que intercala Angulo y Pulgar al comentar el verso "pisa Lesbín, segundo Ganimedes” del soneto "Al marqués de Ayamonte determinado a no ir a México" (OC, I, núm. 164, v. 8). "Don Francisco de Zúñiga —comenta—, hijo suyo [del IV marqués de Ayamonte], segundo gallardo Ganimedes y tan heroico garzón y de tan excelentes partes que parece haber nacido en la celebrada isla de Lesbos"121. Huelga recordar que Góngora no dice "heroi-

120 Díaz de Rivas, op. cit., anotación 83. El propio Díaz de Rivas "satisface la duda", alegando que las doncellas eran robustas porque no eran jóvenes, lo cual es falso, y que hay precedentes literarios de mujeres varoniles, lo cual es cierto. "Estas doncellas, nacidas en las riberas del mar y ejercitadas en la pesquería de la fisga desde sus tiernos años, ¿qué mucho, crecidas en edad, matasen pescados grandes? [...] Fuera de que, como el fin del poeta sea admirar y deleitar con la novedad, muchos, contra el uso común, introdujeron en sus obras fuertes mujeres y valientes, como Homero las amazonas, Virgilio a Camila, el Ariosto a Bradamante y Marfisa, el Tasso a Clorinda, y otros excedieron mucho más que nuestro poeta en atribuirles fortaleza". Sobre el tema puede verse Sharon Fermor, "Movement and Gender in Sixteenth-Century Painting", en The Body Imaged: The Human Form and Visual Culture Since the Renaissance, eds. Kathleen Adler y Marcia R. Pointon, Cambridge (Massachusetts), Cambridge UP, 1993, pp. 129-145; y Elizabeth Cropper, "On Beautiful Women, Parmigianino, Petrarchismo, and the Vernacular Style", The Art Bulletin, 58, 3 (1976), pp. 374394. Sobre la ortopedia de los cuerpos —qué sexo puede hacer qué cosas y de qué manera-, es indispensable Baldassare Castiglione, El cortesano, ed. Mario Pozzi, trad. Juan Boscán, Madrid, Cátedra, 2011, si bien la traducción de Boscán no siempre resulta fiel a la letra del original. Ver, por ejemplo, este pasaje acerca de la robustez de las mujeres: "Pues que yo', respondió el Magnífico, 'tengo licencia de formar esta dama a mi placer, no solamente no quiero que use esos ejercicios tan impropios para ella, pero quiero que aun aquéllos que le convienen los trate mansamente, y con aquella delicadeza blanda que, según ya hemos dicho, le pertenece" (lib. 3, sección 8, p. 354). El original es mucho más enfático: "Rispose il Magnifico: Poich' io possa formar questa Donna a modo mio, non solamente non voglio ch'ella usi questi esercizi virili, cosi robusti ed asperi [ejercicios viriles, tan robustos y ásperos], ma voglio che quegli ancora che son convenienti a donna, faccia con ri guardo, e con quella molle delicatura che avemo detto con venirsele". El rasgo definitorio de la virilidad es la robustez.

121 Martín de Angulo y Pulgar, Varias poesías (Loja, 1639). Apud Juan Matas Caballero 
co garzón”, sino “garzón bello" (OC, I, núm. 171, v. 1). Como tampoco dice "segundo gallardo Ganimedes", sino "segundo Ganimedes" a secas; es decir, cazador como Ganimedes antes de que el águila de Júpiter lo cazara a él, y, además, en relación con Lesbino, el erómeno del sultán Solimán en la Gerusalemme liberata de Tasso (no el semental de una isla poblada de mujeres, como insinúa Angulo y Pulgar) ${ }^{122}$. El comentario de Jammes habla por sí solo: "El hijo del marqués de Ayamonte debía ser aún muy joven [¿como el príncipe de las Soledades?] en esa fecha: es lo que sugiere el último verso de este soneto, en el cual Góngora arroja un púdico velo ('no sepa más...') sobre la aventura de Ganimedes, de la que se niega a precisar la exacta significación" ${ }^{123}$. ¿A qué se deben tantas ambigüedades? Más allá de la presunta homosexualidad del propio Góngora ("tú, puto, no lo niegues") 124, yo lo atribuiría al axioma de la neutralidad que gobierna su poesía. El género en Góngora es a menu-

(ed.), Sonetos de Luis de Góngora, Madrid, Cátedra, 2019, p. 790. Hasta donde sé, el manuscrito de Angulo y Pulgar no se ha publicado.

122 Sobre los rasgos homosexuales del Lesbino de Tasso, ver Marc David Schachter, "Q Quanto concede la guerra': Epic Masculinity and the Education of Desire in Tasso's Gerusalemme Liberata", en The Poetics of Masculinity in Early Modern Italy and Spain, eds. Jane Tylus and Gerry Milligan, Toronto, Centre for Reformation and Renaissance Studies, 2010, pp. 213-240. Según Giovanni Pozzi, el personaje remite a la "tradizione del guerriero giovane e bello, inaugurata da Virgilio con Eurialo (Aeneis, IX, 176), portata all'estremo della morbidezza equivoca in Tasso con la figura di Lesbino"”. Apud Jesús Ponce Cárdenas, "Formas breves y géneros epidícticos entre Tasso y Góngora: el ciclo a los marqueses de Ayamonte", Romanische Forschungen, 122 (2010), pp. 183-219 (p. 206). Subrayo la frase "morbidezza equivoca", 'suavidad equívoca'. Respecto a Euríalo, basta citar las palabras de Virgilio, Eneida, ed. bilingüe Rafael Fontán Barreiro, Madrid, Alianza, 1990: "Niso y Euríalo los primeros, / Euríalo señalado por su belleza y en la flor de la edad [Euryalus forma insignis uiridique iuuenta], / Niso con piadoso amor por el muchacho [Nisus amore pio pueri]" (lib. 5, vv. 294-296); "a su lado [de Niso] Euríalo, su amigo [et iuxta comes Euryale], más hermoso [pulchrior] que el cual / no hubo otro entre los Enéadas" (lib. 9, vv. 179-180). En otras palabras, como la pareja de Lesbino y Solimán, es también una amistad con tintes homoeróticos. La bibliografía sobre el tema es considerable. Ver siquiera Philip Hardie, "The Nisus and Euryalus Episode" en su edición de la Aeneid. Book IX, Cambridge, Cambridge University Press, 1994, pp. 23-34; especialmente la sección sobre "Amicitia and amor", pp. 31-34.

123 Jammes, La obra de don Luis de Góngora y Argote, p. 358, n. 102.

124 Quevedo, "Otro soneto al mesmo Góngora", op. cit., p. 1177, v. 14. 
do una categoría neutral; "ni lo uno ni lo otro"125. Y así muchos de los personajes que circulan por sus composiciones son andróginos o medio andróginos: Alción ("nombre supuesto de pescador, bien que conviene más a mujer que a hombre, y en este sentido le hallamos en los autores antiguos") ${ }^{126}$, Santa Teresa ("monja ya y fraile"), la amada "montaraz y endurecida" del soneto "Verdes juncos del Duero a mi pastora" (OC, I, núm. 127, v. 12), Acis, el peregrino de las Soledades, el príncipe a caballo, Éfire, Lícidas, Micón, los “musculosos jóvenes desnudos” que envidian la belleza de Micón, Miguel de Guzmán en el controvertido soneto "Tonante monseñor, de cuándo acá" 127 y Francisco Manuel Silvestre de Guzmán, garzón bello, segundo Ganimedes (cazador delicado como Ganimedes, sin connotaciones sexuales) y duplo de Lesbino (con resabios sexuales).

Cuando repase las fuentes literarias del pasaje — La colosal estatua ecuestre del emperador Domiciano de Estacio, el canto noveno de la Gerusalemme liberata de Tasso y el retrato ecuestre de los Cazadores de Filóstrato el Viejo- volveré sobre el tema de la ambigüedad sexual. Por el momento, me quedo con la duda: ¿Un retrato sexualmente ambiguo del conde de Niebla? ¿El Capitán del Mar Océano un segundo Ganimedes? ¿A los treinta y cinco años? ¿Dónde están las "botas y espuelas" de Espinosa?

125 Dicccionario de Autoridades, op. cit.: “Término gramático que se aplica al género de aquellos nombres que ni son masculinos ni femeninos, como quien dice: 'Ni lo uno ni lo otro'” (s. v. neutro).

126 García de Salcedo Coronel, Obras de don Luis de Góngora, comentadas, Madrid, Diego Díaz de la Carrera, 1645, t. 2, primera parte, p. 477.

127 Ver, por ejemplo, Manuel Pérez Asensi, Literatura y filosofía, Madrid, Síntesis, 1995: “Tanto el joven muerto [Miguel de Guzmán] como el personaje mitológico inmortalizado [Ganimedes] son presentados bajo rasgos de delicadeza, pasividad, femenidad, inmadurez y mancebía: ‘joveneto', 'garzón', 'bello', 'alhelî’” (p. 52). Para la opinión contraria, ver la edición de los Sonetos de Góngora de Juan Matas Caballero, pp. 1347-1358, quien no cita el importante estudio de Pérez Asensi. 


\section{LA SUAVE Y DELICADA NATURALEZA}

La tercera explicación tiene que ver con la estética manierista, toda vez que el ideal artístico de la masculinidad de la segunda mitad del siglo XVI - Parmigianino, Bronzino, Francesco Salviati ("vivía y vestía a la moda señorial, cabalgaba sobre caballos bellísimos”) (Fig. 3) ${ }^{128}$, Pontormo, Rosso Fiorentino, Correggio, determinadas posturas de Pedro Machuca, el Berruguete de la etapa italiana, no pocos retratos del Greco, la Escuela de Fontainebleau al completo- es un ideal andrógino que huye a un mismo tiempo de los cuerpos musculosos y de los contornos perfilados ${ }^{129}$. Ni sexos ni formas duros; todo "neutral", "suave", "indiferente", "indeterminado". Y un nuevo concepto que volveremos a encontrar: tenerezza, 'ternura'. La ternura del pintar y del decir. Lo introduce Dolce en su Diálogo de la pintura (1557), uno de los primeros tratados de pintura en defender abiertamente la estética del borrón:

Considero que un cuerpo delicado [delicato] debe anteponerse a uno musculoso [muscoloso], y la razón es que es más complicado para el arte imitar las carnes que los huesos, porque en éstos no hay más que dureza [durezza], y en aquéllas se presenta exclusivamente la ternura [tenerezza], que es la parte más difícil de la pintura [...]. Para concluir (además de que al ojo le agrada más un desnudo amable y delicado [gentile e delicato] que uno robusto y musculoso

128 Giovanni Battista Armenini, De los verdaderos preceptos de la pintura, ed. y trad. María Carmen Bernárdez Sanchís, Madrid, Visor, 1999, lib. 1, cap. 1, p. 54.

129 Creo que Gilles Deleuze lo ha dicho bien en su curso sobre la pintura, Pintura. El concepto de diagrama, trad. Equipo editorial Cactus, Buenos Aires, Cactus, 2007: "Tomen las figuras de Miguel Ángel, las figuras de Tintoretto, las figuras de Velázquez. Si hablamos de modo muy anecdótico, la primera impresión que tenemos es una mezcla de extraordinario afeminamiento, de amaneramiento en la actitud, en la pose, y algo de exuberancia muscular. Como si se tratara a la vez de un cuerpo muy fuerte y un cuerpo singularmente afeminado" (p. 102). Los ejemplos son desafortunados (no hay afeminamiento alguno en Velázquez), pero la tesis de la androginia de los cuerpos no admite réplica. Dolce, op. cit., p. 169, lo expresa así: "No sabe [Miguel Ángel] o no quiere observar la diversidad de las edades [età] y de los sexos [sessi]". O sea, no respeta la convenevolezza y pinta mujeres demasiado robustas o, como es el caso del Cristo de la Minerva, un hombre de brazos masculinos y caderas de mujer. 
[robusto e muscoloso]), os remito a las cosas de los antiguos, quienes han tratado principalmente de hacer sus figuras delicadísimas $[\text { delicatissime }]^{130}$.

La delicadeza está relacionada con la sensualidad de la carne y el colorito veneciano, mientras que la robustez se identifica mejor con el dibujo y la terribilitá de Miguel Ángel, todo músculo pero sin dolcezza ("esta delicadeza es llamada dulzura por los pintores”) ${ }^{131}$; sin aquella ternura del encarnado que es, a partir de la segunda mitad del siglo XVI, la parte más difícil de la pintura.

El ejemplo paradigmático sería Venus y Adonis de Tiziano (fig. 4): el retrato de un cazador andrógino en la flor de la edad, tal como el joven príncipe de las Soledades. La écfrasis de Dolce es una de las más célebres de la Historia del Arte:

Fue esta poesía de Adonis poco tiempo atrás enviada por el divino Tiziano al rey de Inglaterra [Felipe II]. Y para empezar por la forma, él lo ha representado con estatura conveniente a un muchacho [garzone] de dieciséis o dieciocho ańos bien proporcionado, con gracia [gratioso] y en todas sus partes elegante [leggiadro], con una amable tinta carnal [tinta di carni amabile] que le demuestra delicadísimo y de sangre real [delicatissimo e di sangue reale $]^{132}$.

130 Dolce, op. cit., p. 143. La suavidad de los cuerpos masculinos despierta siempre el fantasma de la homosexualidad, de modo que Fabrini replica inmediatamente: "La delicadeza [delicatezza] de los miembros pertenece más a la mujer que al hombre". A lo que Aretino responde: "Esto es cierto, y ya os he dicho antes, como máxima, que no se deben confundir los sexos. Pero esto no quita que no existan muchísimos hombres delicados [delicati], como se ve en los gentilhombres [geltilhuomini], que, sin embargo, no se parecen ni a las mujeres ni a Ganimedes" (p. 143). ¿Se puede ser delicado sin parecerse a Ganimedes? ¿Lo es el peregrino de las Soledades, que se parece al cazador Ganimedes? ¿Y el príncipe cazador de la segunda Soledad? ¿Como máxima no se deben confundir los sexos pero en algunos casos individuales sí? ¿Dónde exactamente radica la diferencia entre la delicadeza y el afeminamiento? Observaciones de interés en Fredrika H. Jacobs, "Aretino and Michelangelo, Dolce and Titian: Femmina, Masculo, Grazia", The Art Bulletin, 82, 1 (2000), pp. 51-67.

131 Dolce, op. cit:: "Laqual delicatezza da pittori è chiamata dolcezza" (segunda parte, p. 140).

132 Dolce, Carta de Lodovico Dolce a Alessandro Contarini (h. 1554-1555), en Diálogo de la pintura, pp. 233-237 (p. 235). 
Y continúa diciendo:

Se ve que en la expresión del rostro este único maestro [Tiziano] ha tratado de exprimir una graciosa belleza que, aun participando de lo femenil, no se alejase de lo viril [certa gratiosa bellezza che participando della femina, non si discostasse però dal virile]. Quiero decir que como mujer tendría no sé qué de hombre [che in donna terrebbe non so che di huomo], y como hombre algo de hermosa mujer [et in huomo di vaga donna]; difícil mixtura [mistura diffcile], grata y sumamente preciada por Apeles (si creer debemos a Plinio) $)^{133}$.

Gracia, leggiadria, morbidezza de las carnes, delicadeza, no sé qué, hombres con algo de mujer y mujeres con algo de hombre: el pasaje es un verdadero compendio del ideario estético tardo-quinientista con el que Góngora se identifica plenamente; el ideario de Tiziano, que pronto pasará de las amables tintas carnales de Venus y Adonis (1554) a los verdaderos chafarrinones del Martirio de San Lorenzo (1564-67, Real Monasterio del Escorial) y de San Jéronimo (h. 1575, Real Monasterio del Escorial). "Ni demasiada hermosura [vaghezza] en el colorido ni demasiada policía [politezza, 'aseo', 'limpieza'] en las figuras”, dice Dolce ${ }^{134}$. Si la naturaleza no tiene contornos "duros", ¿por qué habría de tenerlos la figura? Se necesita que "la mezcla de colores sea esfumada [sfumata] y compacta de tal modo que se represente el natural sin dejar cosa alguna que ofenda los ojos, como, por ejemplo, las líneas de los contornos, que se deben evitar (pues la naturaleza no las hace)"135. Los contornos ofenden; delimitar demasiado el límite del objeto le resta "ternura". "La pintura quiere ser representada tierna, pastosa y sin contornos [tenera, pastosa e senza terminazione]" (Fig. 5) ${ }^{136}$; con la "gracia y verdadera pastosidad que se encuentra en la suave y delicada [morbida e delicata] naturaleza"137; "formando

133 Ibidem, p. 235.

134 Lodovico Dolce, Diálogo de la pintura, tercera parte, p. 155.

135 Lodovico Dolce, ibidem, p. 153.

136 Marco Boschini, La carta del navegar pitoresco con la Breve Instruzione pressa alle

Ricche minere della pittura veneziana, ed. Anna Pallucchini, Venecia, Istituto per la Collaborazione Culturale, 1966, p. 748.

137 Francesco Scanelli, Il microcosmo della pittura (1657), ed. Eliana Monaca, Roma, 
las carnes suaves y pastosas [morbide e pastose] mediante un buen golpe de pincel" 138 .

Hermano del "pincel süave" del Greco (OC, I, núm. 269, v. 2), el "pincel süave" de la fantasía, como lo llama en el Polifemo ("pincel süave / lo ha bosquejado ya en su fantasía" (vv. 251-252), el "süave estilo" de Góngora (Sol. 1, v. 40) sería la expresión literaria de la maniera de Tiziano ("por la mancha, es maniera") ${ }^{139}$, y el príncipe cazador de las Soledades un segundo Adonis delicadísimo y de sangre real; "mujer hombre y hombre mujer [femmina masculo e masculo femmina]"140; una "mezcla difícil" del vir militaris y el puer delicatus de Catulo (ciclo de Juvencio, en particular los poemas 24 y 28), Horacio (epodo 11) y Tibulo (el ciclo de Márato, lib. 1, elegías 4, 8 y 9).

\section{ORATIO SOLUTA Y ORATIO VINCTA}

Con ello no quiero decir que el retrato de las Soledades se inspire en el célebre cuadro de Tiziano, que, debido a sus tintas carnales, precisamente, se guardaba en el camerino secreto de Felipe II, donde sólo la nobleza más

Università degli Studi di Roma "Tor Vergata", 2010: "Grazia e vera pastosità che si ritrova nella morbida e delicata naturalezza” (lib. 2, cap. 10, p. 277).

138 Marco Boschini, Le ricche minere della pittura veneziana, Venecia, Francesco Nicolini, 1674: "Formando le carni morbide e pastose di bel' tocco di pennello" (s. p.).

139 Marco Boschini, La carta del navegar pitoresco con la Breve Instruzione: "Per la macchia, ed è maniera; per l'unione de'colori, e questo è tenerezza" (Breve Instruzione, p. 752).

140 Mario Equicola, Libro di natura d'amore, Venecia, 1526: "Il volto de la donna si lauda se ha fatezza di huomo, del huomo il viso se ha fatezza femminile. Onde il proverbio quasi per ciascun luogo: 'Femmina masculo e masculo femmina hanno gratia" (lib. 2, f. 75r.). Ver el buen estudio de Eleanor Webb, "Femmina masculo e masculo femmina: Androgynous Beauty and Ambiguous Sexualities in the Italian Renaissance”, Comitatus, 49 (2018), pp. 103-135. La obra de Equicola se reeditó, que yo sepa, en 1531, 1536, 1554, 1563 y 1607, y es una de las fuentes directas de La Galatea de Cervantes. 
encumbrada podría verlo ${ }^{141}$. Ni siquiera la reina lo tenía permitido ${ }^{142}$. Si el retrato de Góngora se parece a un cuadro es, como se verá más adelante, al retrato ecuestre del Greco: San Martín de Tours y el mendigo (Fig. 25). Por el momento, sólo quiero subrayar el parentesco existente entre la dulce confusión gongorina y la suavidad de la pintura de borrones veneciana. Y tampoco cualquier suavidad; "la verdadera suavidad, aunque de cerca esté aborrononada, golpeada y pastosa, como lo vemos en las cosas de Carreño, Velázquez y otros" (Fig. 6) ${ }^{143}$; "la morbidez, dulzura y suavidad, sin la pensión ['trabajo', 'molestia'] de lo lamido, terso y afectado"144.

141 Luis Tristán, "Las anotaciones de Luis Tristán a las Vidas de Vasari", en El Greco y el arte de su tiempo. Las notas de El Greco a Vasari, eds. Xavier de Salas y Fernando Marías, Madrid, Real Fundación de Toledo, 1992: "Tiénele [Venus y Adonis] su Majestad con muchos otros cuadros. Todos estos [las 'poesías' de Tiziano] es verdad los tiene su Majestad, con una Dánae y otro lienzo de Lucrecia y Tarquino. Tiene estos cuadros hoy [Hernando de] Espejo, guardajoyas, porque su Majestad mandolos guardar por su modestia y gran virtud' (pp. 141-142 [p. 142]). Apud Javier Portús Pérez, "De salas reservadas y otros paraísos cerrados", en VV.AA., El desnudo en el Museo del Prado, Barcelona, Galaxia Gutenberg, 1998, pp. 93-116 (p. 97). Del mismo Portús, ver "Paraíso cerrado. Las salas de desnudos en los palacios de los Austrias, 15541734", en La sala reservada del Museo del Prado y el coleccionismo de pintura de desnudo en la corte española, 1554-1838, Madrid, Museo Nacional del Prado, 1998: "El primer lugar calificable como sala de desnudos es el llamado camerino del Rey Prudente, formado por pinturas mitológicas realizadas expresamente como ciclo por Tiziano, pero de las que se desconoce si en tiempos de su reinado llegaron a convivir siquiera en un único espacio. [...] En 1626 estaban agrupadas en el llamado Cuarto de verano, situado en la zona septentrional del Alcázar madrileńo, un lugar de uso eminentemente privado que coloca estas obras en la esfera de la intimidad real' (pp. 71-128 [p. 73]).

142 Cassiano del Pozzo, El diario del viaje a España del cardenal Francesco Barberini escrito por Cassiano del Pozo, ed. bilingüe Alessandra Anselmi, trad. Ana Minguito, Madrid, Doce Calles, 2004: "Una Venus desnuda, que mostrándonos toda la espalda, sentada sobre una roca, se gira con la cabeza hacia Adonis, intentando apartarle de la caza. [...] Cada vez que la reina entra en este apartamento hace cubrir antes de que lleguen todos los demás los cuadros donde hay desnudos" (pp. 260-261). Nótese asimismo la reacción de Del Pozzo al toparse con el óleo de Diana y Acteón que hoy se encuentra en la National Gallery of Scotland, en Edimburgo: "Resulta increíble la suavidad de aquellas figuras [Non si può credere la morbidezza di quelle figure]" (p. 258). He modificado ligeramente la traducción.

143 Antonio Palomino, El museo pictórico y escala óptica, Madrid, Aguilar, 1988, t. 2, lib. 9. cap. 1, $₫ 3$, pp. 356-357 (p. 357).

144 Antonio Palomino, ibidem, lib. 9. cap. 1, \$3, p. 356. 
La verdadera suavidad no consiste en lo terso, sino en lo indiscernible, "suaves, que non se discerne" 145 .

Esencialmente, la revolución poética de Góngora consiste en aflojar al máximo los vínculos de la cadena sintáctica sujeto-verbo-objeto, de manera que las palabras establezcan entre ellas nuevas relaciones de sentido, con independencia de que obedezcan o no las reglas gramaticales, al modo de la oratio soluta ('discurso suelto') de Quintiliano ${ }^{146}$ y el parlar disgiunto ('hablar desunido') de Tasso ${ }^{147}$.

Aflojar (laxior) los vínculos de unión entre las palabras no es lo mismo que eliminarlos del todo (nullus). Como explica Quintiliano,

no digo esto porque aquella forma libre [solutum] no tenga también ciertos ritmos pertinentes — pies métricos—y tal vez más dificultuosos [difficiliores] [...], pero no poseen el fluido raudal [non

145 El Greco, "Las notas marginales", en Fernando Marías y Agustín Bustamante, Las ideas artísticas de El Greco (Comentarios a un texto inédito), Madrid, Cátedra, 1981, pp. 225-243: "Nela nuestra vista tanto más leyos están suaves que non se discerne" (p. 232); 'en nuestra vista, tanto más lejos están, suaves, que no se discierne'. Suavidad no quiere decir dulce, sino indiscernible. La marginalia del Greco ha sido recogida también en El Greco. Il miracolo della naturalezza. Il pensiero artistico di El Greco attraverso le note a margine a Vitruvio e Vasari, eds. Fernando Marías y José Riello, Roma, Lit Edizioni, 2017, p. 133.

146 Quintiliano de Calahorra, Sobre la formación del orador. Obra completa, ed. bilingüe Alfonso Ortega Carmona, Salamanca, Universidad Pontificia de Salamanca, 19972001: "Ante todo, por tanto, hay un estilo de discurso ligado y entretejido [oratio vincta atque contexta], el otro en una forma de prosa libre [soluta]" (t. 3, lib. 9, cap. 4, 19).

147 Torquato Tasso, Lettere poetiche, ed. Carla Molinari, Parma, Fondazione Pietro Bembo, 1995: "No sé si Vuesa Merced habrá notado una imperfección [imperfettione] de mi estilo. La imperfección es ésta: yo uso con frecuencia el hablar desunido [ilparlar disgiunto], es decir, aquel que se liga más por la unión y dependencia de los sentidos, que por la cópula u otra conjunción de palabras. La imperfección está a la vista, pero muchas veces tiene aspecto de virtud, y a veces virtud portadora de grandeza” (pp. 223-224). Sobre la relación del hablar desunido de Tasso con la pintura de borrones de Tiziano, ver Andrea Emiliani, "Torquato Tasso: tra parlar disgiunto e dipendenza di sensi. Un modello didattico per la comprensione dell'ultima stagione di Tiziano", en Tiziano: L’ultimo atto, ed. Lionello Puppi, Milán, Skira, 2009, pp. 69-75; y Tasso, Tiziano e i pittori del parlar disgiunto. Un laboratorio tra le arti sorelle, eds. Andrea Emiliani y Gianni Venturi, Venecia, Marsilio, 1997. 
fluunt], ni la coherencia [nec cohaerent], ni hacen acercar unas palabras a otras [nec verba verbis trahunt], de suerte que de los vínculos de unión [vincla] entre ellas más bien cabe decir que son más flojos [laxiora $]$ que inexistentes $[\text { nulla }]^{148}$.

La oratio soluta no es más fácil que la oratio vincta atque contexta, el 'discurso ligado y entretejido'. Aunque tropieza a cada paso, deviene incoherente y los vínculos de unión entre las palabras se aflojan — no hay vínculo que sea suave-, es más difícil que aquélla porque su coherencia no es meramente formal, sino inmanente; "una articulación que crece a partir de la lógica misma del material”, en lugar de imponerse artificialmente desde fuera $^{149}$. No es una forma sancionada por la convención, sino lo que Adorno llama una construcción (Konstruktion), "que significa, efectivamente, que el artista tiene que realizar, construyendo, la organización del material, en contraposición al concepto de forma, que supone esta operación, de algún modo, dogmáticamente, como una operación ya consumada" ${ }^{150}$. Construir el sentido es más difícil que simplemente formarlo. Escribir mal en el sentido de aflojar al máximo los vínculos sintácticos (oratio soluta) es más difícil que escribir bien en el sentido de mantenerlos atados de acuerdo a determinada convención gramatical (oratio vincta), y doy un ejemplo. En el verso "pasos de un peregrino son errante" con el que se abren las Soledades, la voz "son" ¿se refiere a la tercera persona del verbo ser (los pasos son) o al sustantivo son (un son errante) ${ }^{151}$ ? En los versos 171-72 de la Soledad primera, por ejemplo, se refiere al sustantivo: "Destempla-

148 Quintiliano de Calahorra, op. cit., t. 3, lib. 9, cap. 4, 20.

149 Theodor Adorno, Estética (1958/59), ed. Eberhard Ortland, prólogo y trad. Silvia Schwarzböck, Buenos Aires, Las cuarenta, 2013: "No es de un tipo de dominio que, de algún modo, se impone al material como algo extrańo, por medio de restricciones, voluntad de estilo, o cualquier otra cosa de esta índole, sino de una articulación que crece a partir de la cosa misma, si ustedes quieren, incluso, a partir de la lógica misma del material. Precisamente por eso esta construcción es necesaria, porque las formas no están más fijadas de un modo ingenuamente inmediato, porque no son más eso que Hegel, en su Estética, caracterizó como sustancial' (p. 193).

150 Adorno, ibidem, p. 194.

151 La pregunta ha sido contestada por Gaspar Garrote Bernal en su "Un experimento con 'el peregrino son errante': la boscarecha de Pedro Espinosa”, Lectura y Signo, 31, 1 (2018), pp. 201-227. Suscribo la tesis del autor con respecto a la "movilidad morfosintáctica de peregrino (sustantivo y adjetivo) y son (verbo y sustantivo)” (p. 213). 
do / son ['sonido'] de cajas". Lo mismo ocurre en los versos 254-55: "Al son ['sonido'], pues, deste rudo / sonoroso instrumento", ninguno de los dos sones particularmente templados. Porque el verso trata de manera explícita sobre la errancia — "peregrino son errante”- y la errancia es un movimiento que no tiene dirección fija, un ejercicio de la más pura neutralidad, por eso mismo no deberíamos escoger. Es verbo y sustantivo al mismo tiempo, dependiendo de cuál verso leamos, si el que escribió Góngora, "pasos de un peregrino son errante", sin comas de ningún tipo, o el que debería haber escrito: "son los pasos de un peregrino errante". El primer verso cortocircuita el segundo; no nos permite llegar directamente al sentido gramatical sino que lo destempla. ¿Pasos? ¿Versos? ¿Pasos dé (verbo)? ¿Pasos de un peregrino (preposición)? ¿Pasos son (verbo)? ¿Versos de un son peregrino (sustantivo)? ¿Peregrino (sustantivo) o peregrino (adjetivo)? ¿Los pasos de un peregrino errante o los versos peregrinos de un son destemplado? El verso es esa indecisión, si la neutralidad del lector sufre consejo y no la fuerza obligación precisa. Esto es, si no se siente compelido a deshacer el hipérbaton y concluir de la manera más económica, como hace Luis de Tejeda en su mediocre El peregrino en Babilonia: "Los pasos que el errante peregrino / dio" ${ }^{152}$. Eliminar la errancia del son equivale a destruir el verso como verso. La oratio soluta no desaparece de ninguna manera detrás de la oratio vincta. Por el contrario, el estilo oscila continuamente entre la solución y la disolución; ahora ata y ahora desata, sin que ninguno de los dos momentos consiga imponerse del todo.

Tan pronto entendemos como dejamos de entender, y esa incertidumbre; no el tipo de ambigüedad que desaparece con consultar el diccionario, sino la ambigüedad que se resiste a desaparecer, la permanente obstrucción del sentido como sentido, ésa es la gran revolución de Góngora. De ahora en adelante la poesía hablará a través del barullo, no antes o después de él. La forma deja de ser escrupulosa o incierta, para convertirse en escrupulosamente incierta: "Fábrica escrupulosa, y aunque incierta, / siempre murada, pero siempre abierta” (Sol. 2, vv. 79-80).

152 Luis de Tejeda y Guzmán, "A las soledades de María Santísima”, en El peregrino en Babilonia y otros poemas, Buenos Aires, Juan Roldán, 1916, pp. 141-213 (p. 141, vv. 1-2). Ver también el estudio de John McCaw, "A Poetics Sacralized: Luis de Góngora's Soledades as Religious Rhetoric in Luis de Tejeda's 'Romance sobre su vida”, Hispanófila, 167 (2013), pp. 3-22. 
Y lo que todavía resulta más sorprendente: porque el sentido es neutral y se resiste a escoger entre el verbo son y el sustantivo son destemplado, por eso mismo dice más. No dice menos: dice más. La riqueza del sentido radica en la incertidumbre del son. Mientras más la pintura se acerca a la suavidad sin contornos de la naturaleza, más se aleja de la figuración (Figs. 5 y 6). Y mientras la lengua se acerca más al centro irradiante del sentido, más se aleja de la discursividad. El verdadero sentido no es discursivo: balbucea un no sé qué; se sirve de los instrumentos del discurso para traer al frente — dice Ormaza — una "ausencia que llega" ${ }^{153}$. Entiéndase: una ausencia que como tal ausencia, todavía así llega. Sin acabar de llegar, no termina de llegar. La perfección de la obra no radica ya en la presencia positiva del objeto, sino en aquel "huir dulcísimo" que describe Daniele Barbaro en su edición comentada de los Diez libros de arquitectura de Vitruvio, libro anotado por el Greco de su puño y letra, y subrayado por él mismo de arriba abajo, como si en las palabras de Barbaro encontrara la respuesta a sus preguntas más urgentes (Fig. 7). La nota se encuentra en el capítulo 5 del libro VII — "Della ragione del dipignere ne gli edificii” o 'Sobre la razón de pintar en los edificios' - y dice así:

\title{
9. UNA TERNURA EN EL HORIZONTE DE LA VISTA
}

\begin{abstract}
Después (que es cosa de poquísimos) y de nuestro tiempo apenas considerada, aunque es la perfección del arte, hacer los contornos dulces y esfumados, de manera que se entienda lo que no se ve, para que el ojo crea ver lo que ve, que es un huir dulcísimo, una ternura en el horizonte de nuestra vista que es y no es [subrayados del Greco] ${ }^{154}$.
\end{abstract}

153 José de Ormaza (Gonzalo Pérez de Ledesma), Censura de la elocuencia (1648), eds. Giuseppina Ledda y Vittoria Stagno, Madrid, El Crotalón, 1985: “Con desvíos nos atrae, con ausencias nos llega, con rodeos nos busca” (p. 192). Sobre Ormaza, ver Paolo Tanganelli, Le macchine della descrizione. Retorica e predicazione nel Barocco spagnolo, Pavía, Ibis, 2011, pp. 95-131 y passim.

154 Marco Vitruvio Polión, I dieci libri dell'architettura di M. Vitruuio, tradutti et commentati da monsignor [Daniele] Barbaro, Venecia, Francesco Marcolini, 1556, lib. 7, ca. 4, p. 188, líneas 37-40. Sobre Barbaro, ver Fernando Marías y José Riello, "La fortuna de Daniele Barbaro en la península ibérica", en Daniele Barbaro, 15141570. Venitien, patricien, humaniste, eds. Frédérique Lemerle, Vasco Zara, Pierre 
In somma poi (che è cosa di pochissimi) ed a nostri di non e a pena considerate, ed è la perfezione dell'arte, fare i contorni di modo dolci e sfumati, che anche s'intenda quello che non si vede, anzi che l'occhio pensi di vedere quello ch'egli vede, che è un fuggir dolcissimo, una tenerezza nell'orizzonte della vista nostra che è e non è.

A la pregunta ¿qué está más allá de los límites de la forma? Barbaro responde: un horizonte de ternura que es y no es. El fin de la pintura no es lo dado, un objeto ajustado a la definición que da de él el diccionario y contenido dentro de los límites que dibujan su forma, sino la huida de ese mismo objeto, fuggire, en el horizonte de la mirada. Y tampoco cualquier clase de huida; el objeto sigue ahí, no se ha movido de su sitio, pero todavía así no ha tenido lugar ni está en ninguna parte. Es atópico; se quedó y se olvidó, más presente que nunca donde nadie aparecía.

La explicación del propio Greco no es menos sorprendente: "La pintura por eser [sic] tan universal se hace especulativa donde nunqua [sic] falta il contento de especulación pues que nunqua falta que ver pues hasta nela $[$ sic $]$ mediocre escuridad ve e goza" ${ }^{155}$. Oratio soluta, casi incoherente, seguida de ésta otra: "Porque no so por decir que pos ['porque'] la pintura trata del imposible por el mismo caso es emperfeta [sic]"156.

¿Qué es lo "imposible”? Varios historiadores de arte se han hecho la misma pregunta sin llegar a una respuesta satisfactoria ${ }^{157}$. Creo que Nan-

Caye y Laura Moretti, Turnhout, Bélgica, Brepols, 2017, pp. 476-478. Sobre la biblioteca del Greco, ver Fernando Marías y Agustín Bustamante, op. cit., pp. 4372; y La biblioteca del Greco, eds. Javier Docampo y José Riello, Madrid, Museo Nacional del Prado, 2014.

155 El Greco, "Las notas marginales", en Las ideas artísticas de El Greco, p. 241. Es decir, "por ser tan universal, la pintura se vuelve especulativa, ya que en ella nunca falta la alegría de la especulación, pues nunca falta materia que ver, ya que hasta en la mediocre oscuridad ve y goza'.

156 Ibidem, p. 227. 'Porque no se puede decir que porque la pintura trate sobre lo imposible, por eso es imperfecta'.

157 Fernando Marías, "El Griego, entre la invención y la Historia”, en El Griego de Toledo, pintor de lo visible y lo invisible, ed. Fernando Marías, Madrid, Fundación El Greco, 2014, pp. 19-45, propone la siguiente: "Este tratamiento de lo imposible por parte de la pintura puede interpretarse de dos maneras distintas. En primer lugar, podría limitarse a esa ilusión paradójica, llegando a 'engañar a los sabios' como 
cy lo define bien: "La extensión infinita de una forma finita"158. La forma es ciertamente finita, pero —evidencia incomprensible — sus límites no se dejan aprehender ${ }^{159}$. Son como "el sonido de las campanas", dice Da Vinci, il suono delle campane ${ }^{160}$; o en palabras de Plinio el Viejo, una "promesa", "porque la misma extremidad se tiene que abrazar a sí, y acabar de tal suerte que prometa otras cosas detrás de sí [promittat alia post

habían hecho ya los pintores antiguos. Pero, también, podría ser que lo imposible sea lo invisible, lo que carece de forma visible por no ser mera y simplemente objeto perceptible, natural, sino supernatural, celestial, divino" (cursivas en el original, p. 38). La respuesta correcta es la segunda - lo invisible-, pero creo que se puede ser más preciso.

158 Según Jean-Luc Nancy, Le Plaisir au dessin, París, Galilée, 2009, p. 128, "la beauté est dans le rapport à l'infinité. Elle expose l'extension infinite d'une forme finie".

159 Paul Valéry, Cahiers, ed. Judith Robinson, París, Gallimard, 1974, II, p. 982, escribió: "evidencia incomprensible. Infinito bajo forma finita [Évidence incomprehensible. Infini sous forme finie] [cursivas en el original]".

160 Leonardo da Vinci, "Modo de aumentar y despertar el ingenio mediante varias invenciones", en Tratado de la pintura: "Si te fijas en algunos muros sucios de manchas variadas o en piedras de varios tipos. Si tuvieras que inventar algunos lugares, podrás ver allí de diversas maneras semejanzas con diversos paisajes, adornados con montañas, ríos, piedras, árboles, grandes llanuras, valles y colinas. Aún podrás ver diversas batallas y acciones preparadas de figuras extrańas, aires de rostros y vestimentas e infinitas cosas, las cuales podrás transformar en una forma completa y buena, que en tales muros y piedras sucede como el sonido de las campanas, que, en los repiques de ellas, escucharás cada nombre y vocablo que imagines [Se tu riguarderai in alcuni muri imbrattati di varie macchie o in pietre di vari misti. Se avrai a invenzionare qualche sito, potrai lì vedere similitudini di diversi paesi, ornati di montagne, fiumi, sassi, alberi, pianure grandi, valli e colli in diversi modi; ancora vi potrai vedere diverso battaglie ed atti pronti di figure strane, arie di volti ed abiti ed infinite cose, le quali tu potrai ridurre in integra e buona forma; che interviene in simili muri e misti, come del suono delle campane, che ne'loro tocchi vi troverai ogni nome e vocabolo che tu t'immaginerai]". La mancha es a la pintura lo que el eco de una campana al lenguaje. La traducción es mía, ya que las versiones del Tratado que existen en español, comprendida la edición de Akal, son deficientes. Para el texto de Da Vinci he seguido la edición digital de Angelo Borzelli, segunda ed. digital, 2006, segunda parte, fragmento 63, disponible en https://www.liberliber.it. Comparar con Vittorio Imbriani, La quinta promotrice, 1867-1868, Nápoles, s. n., 1868: "Una mancha incomparable, que tiraba las cuerdas y ponía en movimiento las campanas de la fantasía [una macchia impareggiabile, la quale tirava le corde e metteva in motto la campane della fantasia]" (p. 42). La mancha aviva la fantasía. 
se] y que muestre también lo que oculta y cubre [ostendatque etiam quae occultat ${ }^{\prime 161}$.

Especulación sensible, intuitiva, la pintura sería la promesa de un objeto radicalmente incierto que se abre en la tela como el eco de una campana (Fig. 8). El pintor ve y goza — goza viendo- incluso en la mediocre oscuridad porque la extensión del objeto, su campo de resonancia, podríamos llamarlo, no termina en los límites de la forma, sino que se prolonga infinitamente, "fantasmático a fuerza de exactitud"162.

Esta forma naciente, esencialmente inacabada, ¿es más perfecta o más "emperfeta” que la forma acabada? Más perfecta, afirma El Greco sin vacilar, si bien su perfección no tiene nada que ver con la clausura del sentido. El sentido está por delante del sentido (pro-missus, 'enviar antes'); no

161 Plinio el Viejo, Historia natural de Cayo Plinio Segundo, trad. Jerónimo de la Huerta, Madrid, Juan González, 1629, t. 2, lib. 35, cap. 10, p. 641. La traducción moderna de María Esperanza Torrego es inferior: "Pues la línea del contorno debe envolverse a sí misma y terminar de modo que deje adivinar otras cosas detrás de sí y enseñe incluso lo que oculta (Textos de historia del arte, Madrid, Visor, 1987, lib. 35, 67). Comparar con Marco Boschini, La carta del navegare pitoresco: "Faceva comparire [Tiziano] in quattro pennellate la promessa d'una rara figura [hacía comparecer en cuatro pinceladas la promesa de una rara figura]" (p. 711). No se pinta una forma cerrada, sino la promesa de una rara figuración; el objeto se debate entre la promesa y la confirmación, o como dirá el Barroco también, entre el golpe y el amago. La paráfrasis de Franciscus Junius también es muy bella: "Los contornos ilimitados de las figuras imitadas en la obra deben dibujarse con tanta delicadeza y tanta dulzura que nos traigan a la representación cosas que no vemos, de manera que nuestro ojo siempre crea que detrás de las figuras queda por verse más de lo que se ve [The unrestrained extremities of the figures resembled in the worke should be drawne so lightly and so sweetly as to represent unto us things we doe not see: neither can it be otherwise but our eye will alwayes beleeve that behind the figures there is something more to be seene then it seeth] (The Painting of the Ancients, lib. 3, cap. 3, $\$ 10$, p. 249). Y acto seguido cita a Plinio: "Terminando con una promesa de otras cosas detrás, y exponiendo lo mismo que esconde [ending with a promise of other things behinde, and setting forth also what shee concealeth]" (lib. 3, cap. 3, $\$ 10$, p. 249).

162 Maurice Merleau-Ponty, El ojo y el espiritu, trad. Alejandro del Río Herrman, Madrid, Trotta, 2013, p. 57. Cursivas en el original. Del mismo autor, también es recomendable "La duda de Cézanne", en Sentido y sinsentido, trad. Narcís Comadira, Barcelona, Península, 1977, pp. 33-56, aunque la traducción es deficiente. 
"dice" sino que da pasos en dirección del decir"163.

Nótese ahora cómo lo expresa Góngora: "Ronca los salteó ['sorprendió] trompa ['cuerno de caza'] sonante, / al principio distante, / vecina luego, pero siempre incierta" (Sol. 2, vv. 710-712). O: "Conservarán el desvanecimiento / los anales diáfanos del viento" (Sol. 2, vv. 142-143). O: "el eco (voz ya entera)" (Sol. 1, v. 673). O traduciendo casi literalmente el interminatos corporum terminos ['cuerpos de términos no terminados'] de Junius ${ }^{164}$ : "ordena / los términos confunda" (Sol. 2, vv. 244-245), "los dudosos términos del día" (Sol. 1, v. 1072), "muertas, pidiendo términos disformes" (Dedicatoria, v. 11); "los términos saber todos no quiere" (Sol. 1, v. 409).

No quiere saber de términos; ordena su confusión; los deforma.

¿Qué dicen estos versos? ¿Decir? Nada; prometen que la poesía conservará el desvanecimiento de un objeto sin límites definidos que se repite como un eco en las páginas diáfanas del viento, y que ese eco, ese cornetazo, sordo, pero también sonoro, mudo y hablante a la vez, esté lejos o esté cerca, nunca es nuestro: se mantiene siempre incierto. "Con desvíos nos atrae, con ausencias nos llega, con rodeos nos busca”. Sólo su ausencia invita. Estando cerca, se mantiene lejos, y estando lejos, se mantiene cerca; "convoca despidiendo" (Sol. 1, v. 85) y "resiste obedeciendo" (Sol. 2, v. 26), sin darse ni dejar de darse nunca.

Lo entero de la voz consiste en el "eco repetido" (Dedicatoria, v. 9) donde la voz se pierde. La voz es sólo el golpe de campana; lo que cuenta es la promesa de la repetición ${ }^{165}$.

163 Apreciaciones inestimables al respecto en Gilles Deleuze, Francis Bacon: Lógica de la sensación, trad. Isidro Herrera, Madrid, Arena, 2016, pp. 123-136.

164 Franciscus Junius, De pictura veterum, Ámsterdam, Iohannem Blaeu, 1637: "Interminatos corporum terminos tam leviter leniterque ductos" (lib. 3, cap. 3, $\$ 10$, p. 172). La traducción del propio Junius se halla en la nota 161. Interminatos corporum terminos quiere decir 'los contornos indeterminados de las figuras'. Comparar con Luis de Tejeda, imitador servil de Góngora: "Mezclado entre pardas nubes / formar un confuso mapa / y prometerle a la vista / con engañosa esperanza / términos imaginarios / de horizontes y de rayas (op. cit., p. 88, estrofas 32-33). No describe un paisaje, sino, como diría Dolce, una "mancha de paisaje [macchia di paese]" de contornos confusos y engañosos (Diálogo de la pintura, p. 185).

165 Sobre la poética del eco — la Nada que habla—, ver Emanuele Tesauro, Cannocchiale aristotelico, esto es, Anteojo de larga vista o idea de la agudeza e ingeniosa locución, trad. Fray Miguel de Sequeiros, Madrid, Antonio Marín, 1741: "Hablando de la Eco, 
¿Ambigüedad sexual? Es la menor de las ambigüedades de Góngora. La ambigüedad sexual delata un desequilibrio ontológico más profundo. La pregunta de Góngora no es tanto si el príncipe de las Soledades es fuerte o delicado, robusto o no robusto, Marte o Ganimedes - es las dos cosas y ninguna de las dos_-, sino más bien dónde están los límites del retrato, si el objeto de la representación es y no es y si la poesía trata sobre lo posible o sobre lo imposible; si el arte es meramente un deleite de los sentidos o si es, como afirma Bergson, "una metafísica figurada [cursivas en el original]" 166 .

Por lo que respecta a la ternura del pincel, y aunque yo me hubiese ahorrado la chuscada sobre Hamlet, no tengo nada que añadir a las siguientes palabras de Badiou:

La cuestión del dibujo difiere bastante de la pregunta de Hamlet. No se pregunta "ser o no ser", sino "ser y no ser". Tal es la razón de la fragilidad [fragilité] fundamental del dibujo: no la clara alternativa entre ser y no ser, sino una sombría y paradójica conjunción entre ser y no $\operatorname{ser}^{167}$.

que en la selva o en los montes representa nuestras voces, puedes decir: 'Ella es un alma inánime, muda a un tiempo y facunda [mutola insieme e faconda], que habla sin lengua; hombre y no hombre, que forma las voces sin respiración; imagen sin figura [imagine senza figura], que en el aire pinta las voces sin colores; no es tu hija, y tú la has engendrado; tú la oyes, y no la ves; ella te responde, y no te oye; ella es una Nada hablante, que habla sin saber hablar y propiamente habla [una Nulla parlante, che non sà parlare e pur parla]; o habla sin saber lo que se dice [o parla senza sapere ciò che si dica]'. Todas proposiciones maravillosas, pero verdaderas" (t. 2, cap. 7, p. 42). He corregido ligeramente la traducción, que en general es excelente.

166 Según Henri Bergson, "La vida y la obra de Ravaisson", en El pensamiento y lo moviente, trad. Pablo Ires, Buenos Aires, Cactus, 2013, p. 261, "toda la filosofía de M. Ravaisson deriva de esta idea de que el arte es una metafísica figurada, que la metafísica es una reflexión sobre el arte, y que es la misma intuición, diversamente utilizada, la que produce el filósofo profundo y el gran artista” (p. 261). Es, sin duda, la ambición de El Greco cuando declara que la tarea de la pintura no es sólo pintar lo sensible, sino especular sensiblemente acerca de una aparición que trasciende la figuración.

167 Alain Badiou, "Drawing”, Lacanian Ink, 28 (2006), pp. 42-49. Lo cita Nancy en Le Plaisir au desin, p. 34. La traducción al español que circula en Internet es prácticamente ilegible. 
"Tan incierto / que da ser y no ser", dice Paravicino ${ }^{168}$.

Por "ser y no ser" debemos entender siempre: la forma completa, acabada, pero no totalizable, de una ofrenda que no termina de darse, es decir, que no acaba de darse del todo y que no deja de hacerlo; la forma de un prometer.

¿Hasta qué punto puede estar abierta la forma sin que se disuelva en la incoherencia? (Fig. 9). Pero también y con la misma urgencia: ¿hasta qué punto puede permanecer encerrada sin entumecerse? ¿Qué margen de indeterminación tiene el sentido? Son preguntas que atraviesan la obra de Góngora de parte a parte. "El arte lucha con el caos, pero para hacerlo sensible"169. No niega el caos; lucha con él para hacer sensible una "dulce confusión" (Sol. 1, v. 485) (Fig. 10).

"Incierto" no quiere decir, entonces, falto de certeza. A la incertidumbre de Góngora no le falta nada; está perfectamente lograda. Pero no en el sentido de un decir cerrado, ni tampoco abierto a cualquier clase de interpretación. Un sentido no-totalizable inseparable del desvanecimiento; un sentido que tan pronto trae algo, inmediatamente lo retrae, repitiendo hasta el cansancio "sí, pero no", "el sí y el no de que estamos ya todos tan ahítos, no es de su cosecha malo, pero es mal usado de V.m. [Góngora] y mal repetido" 170 .

¿Por qué el "no" al lado del "sí", o del sonido "si”? ¿Por qué, por ejemplo, "si de miembros no robusto" en lugar de 'de miembros delicados', que significa lo mismo? Porque no significa lo mismo. 'De miembros delicados' es una afirmación y Góngora preferiría no tener que afirmar. Es "árbitro igual" (Sol. 1, v. 55); no escoje. Antes, "un rubí concede o niega / (según alternar le plugo)” (OC, I, núm. 317, vv. 61-62). Alterna según le plazca entre afirmar y negar, desandando los pasos andados

168 Paravicino, op. cit, p. 184: "Tu sol, Clori, no influía tan incierto / que da ser y no ser a espacio breve, / y es rigor el lucir, más que hermosura" (vv. 12-13).

169 Gilles Deleuze y Félix Guattari, ¿Qué es la filosofía?, trad. Thomas Kauf, Barcelona, Anagrama, 1994, p. 206. Ver igualmente Deleuze, Pintura, donde ya desarrollaba la misma tesis: "Hace falta que el cuadro dé testimonio de este atravesamiento: un abismo ordenado. Un abismo es nada. Un cuadro que sea orden es nada. Pero el orden propio al caos, la instauración de un orden propio al abismo, ése es el asunto del pintor" (p. 103).

170 Juan de Jáuregui, Antídoto contra la pestilente poesía de las Soledades, ed. José Manuel Rico García, Sevilla, Universidad de Sevilla, 2002, p. 40. 
y "construyendo con un mismo verbo dos oraciones, una afirmativa y otra negativa"171. "No robusto", es decir, ni robusto ni delicado, sino negativamente robusto, robusto a través del no. La lítote gongorina es un conceder negando ${ }^{172}$. Concede que el objeto aparezca y diga "ligeras", "coro", "rudos", "tierra", "vacío", pero bajo el veto de la negación: "señas no ligeras" (Sol. 2, v. 561), "no mudo coro" (Sol. 2, v. 720), "números no rudos" (Sol. 2, v. 536), "no poca tierra” (Sol. 2, v. 162), "pequeños no vacíos" (Sol. 1, v. 955) 173. "Si”" y "no" se pertenecen mutuamente. La lengua está internamente bloqueada. No se postula nada, no se afirma nada, nada es traído a la presencia sin antes atravesar la resistencia del "no". Como en el "manerismo" esquizofrénico, "al orden de las palabras se le ha atravesado algo, a saber: el 'no"'174. El coro no canta ni deja de

171 Anónimo, Diálogos en que se contienen varias materias y se explican algunas obras de D. Luis de Góngora (d. 1623 y a. 1627), ed. Francesca dalle Pezze, Verona, Fiorini, 2007, diálogo 5, p. 166. Otro tanto dice Pedro Díaz de Rivas, Anotaciones y defensas a la primera Soledad, Ms. 3726 de la Biblioteca Nacional de España: "El 'sí y el 'no' apartados tienen energía y significan repugnancia, porque el 'sî' es particular afirmativa y el 'no', negativa” (ff. 104-179 [f. 128]). Ver las lúcidas reflexiones al respecto de Alain Badiou, Que pense le poème?, Caen, Nous, 2016: "El poema es una maquinaria negativa que enuncia el ser o la Idea en el mismo punto donde el objeto se desvanece [le poème est une machinerie négative, qui énonce l'être, ou l'idée, au point même où l'objet s'est évanoui]” (p. 20).

172 Según Tesauro, op. cit., I, cap. 3, p. 49, "las cosas más altas y peregrinas nos vienen cubiertamente descubiertas y pintadas con sombras a lo claro y a lo oscuro [le cose più alte e peregrine ci vengono copertamente scoperte, e adumbratamente dipinte à chiaro oscuro]".

173 Ver al respecto Jáuregui, op. cit., p. 50: "Epítetos simples o tan inoportunos como ahora éstos: 'Plumas no vulgares' (v. 793), 'amor no omiso' (v. 1072), 'golpe no remiso' (v. 693)”. Encuentra impropio el abuso de la lítote.

174 Ludwig Binswanger, Tres formas de la existencia frustrada: Exaltación, excentricidad, manerismo (1956), trad. Edgardo Albizu, Buenos Aires, Amorrortu, 1972, p. 185, opinaba que "cuando en lugar de leer 'Mozart y Hayden', leemos 'Mozart no y Hayden', de ningún modo puede decirse que sólo tengamos la 'impresión' de lo atravesado, sino que comprobamos que al orden de las palabras se le ha atravesado algo, a saber: el 'no'" (p. 185). Binswanger es el padre de la psicología existencial de corte heideggeriano. Al comparar el "manerismo" esquizofrénico con el "manierismo" literario — aunque se parecen, no son la misma cosa—, el propio Binswander recuerda a Góngora: "Su flor más exquisita [del manierismo] se halla en el gongorismo español, que procede del poeta Góngora y sus sucesores” (ibidem, p. 173). 
cantar: no mudo canta, entonando sin descanso el son destemplado de un "cántico impedido" (Sol. 2, v. 621) ${ }^{175}$.

\section{Majestad heroica y desatada majestad}

Joven, augusto sin ser robusto, algo andrógino... Todavía queda un rasgo del príncipe por aclarar: la majestad.

La espumosa del Betis ligereza

bebió no solo, mas la desatada

majestad...

Según Blanco, “desatar es en la lengua gongorina un neologismo de acepción que no posee sinónimos en el español corriente. Algo se desata cuando fluye, se dispersa, se vierte o derrite, se disuelve con rapidez y abundancia" ${ }^{176}$. En efecto, el epíteto esperado no es "desatada / majestad", con encabalgamiento de por medio, como si entre el participio y el nombre se abriera un vacío, sino majestad heroica. Así en La vida es sueño de Calderón:

Generoso Segismundo, cuya majestad heroica sale al día de sus hechos de la noche de sus sombras ${ }^{177}$.

175 El uso sistemático de la negación por parte de Góngora apenas ha sido estudiado. Sobre la historia del concepto, ver Laurence R. Horn, A Natural History of Negation, Stanford (California), CSLI Publications, 2001. Sobre las oraciones negativas en castellano, es útil Ignacio Bosque, Sobre la negación, Madrid, Cátedra, 1980. Góngora agota el repertorio de lo que los lingüistas modernos llaman AANN o activadores negativos: de duda (dudar, ser dudoso), de oposición (negar, oponerse, impedir, ser contrario, ser opuesto), de privación (quitar, irse, perder, falta de), ciertos factivos emotivos (molestar, indignar, horrible), preposiciones y conjunciones como sin y si, y los cuantificadores indefinidos, especialmente poco y apenas. Para el "impedimento" y su relación con lo sublime longiniano, ver Huergo Cardoso, op. cit., pp. 156-159.

176 Mercedes Blanco, Góngora o la invención de una lengua, León, Universidad de León, 2012, p. 312.

177 Calderón de la Barca, La vida es sueño, edición José M. Ruano de la Haza, Madrid, 
La majestad heroica del príncipe Segismundo, con el adjetivo pospuesto al sustantivo y sin encabalgamiento, logra imponerse a las sombras y salir de la noche al día. En cambio, la desatada majestad del príncipe anónimo de las Soledades, con el adjetivo antepuesto al sustantivo y con encabalgamiento, ya es más dudoso si sale o no sale.

Otros epítetos normales de majestad serían: "cesárea majestad” 178 ; “imperial majestad"179; "grave majestad pesada"180; "soberbia majestad cuya belleza / aun la envidia negarla no se atreve"181; "majestad severa"182; "de firme majestad", etc. ${ }^{183}$

El sintagma "desatada / majestad" es oximórico y designaría, como indica Blanco, un poder suelto y desleído, deshecho, en lugar de unido y condensado, un poder suave ${ }^{184}$. El participio desata lo que la majestad ata, homófonos “desATADa” y “mAjesTAD”, además: opuestos en el sentido pero iguales en el sonido.

Desatar — des-hacer, des-anudar, des-ligar, des-vincular- es vocablo gongorino con un amplio radio de acción. Menciono rápidamente algunos ejemplos:

Mi libertad vuestra es,

y mi lengua, desatada.

(OC, I, núm. 131, vv. 58-59).

¿Qué tipo de lengua? Desatada, libre; parlar disgiunto (Tasso).

Castalia, 1994, p. 291, jornada III, cuadro 3, vv. 2690-2693.

178 Balbuena, op. cit.: "Sin respetar la grave imperial silla, / la cesárea majestad en ella" (t. 2, lib. 22, estrofa 73).

179 Ibidem, I, p. 209, lib. 3, estrofa 165.

180 Ibidem, I, p. 164, lib. 2, estrofa 179.

181 Ibidem, I, p. 488, lib. 9, estrofa 170.

182 Ibidem, I, p. 624, lib. 12, estrofa 120.

183 Ibidem, II, p. 1034, lib. 21, estrofa 99.

184 Ver Dolce, Diálogo de la pintura, p. 88: "Tiziano, que dio a sus figuras una heroica majestad [heroica maestà] y halló un estilo de colorido tan suave [morbisissima] y en las tintas tan parecido a lo verdadero que bien se puede afirmar, en verdad, que va a la par de la naturaleza”. Nótese de nuevo: ser fiel a la naturaleza es ser fiel a la suavidad de las figuras, incluso si transpiran, como el retrato de Carlos Ven la batalla de Mühlberg, una heroica majestad. La mímesis pasa necesariamente por la disolución de la mímesis. 
Segundo ejemplo:

En lo viril desata, de su vulto,

lo más dulce...

(Fabula de Polifemo y Galatea, vv. 285-286).

La virilidad se desata en dulzura; "como mujer tendría no sé qué de hombre y como hombre algo de mujer” (Dolce).

Tercer ejemplo:

De los nudos, con esto, más süaves,

los dulces dos amantes desatados.

(Fabula de Polifemo y Galatea, vv. 473-474).

Repite el axioma de las Soledades: desatar los nudos, que "aun de seda no hay vínculo süave" (Sol. 2, v. 808).

Cuarto ejemplo:

Mucho es más lo que (nieblas desatando)

confunde el Sol y la distancia niega.

(Sol. 1, vv. 195-196).

Paisaje flamenco, pero nuboso, abocetado, a caballo entre el Paisaje con san Jerónimo de Patinir y la Vista de Toledo del Greco. Las nubes invaden el cuadro. Si todavía pinta, mucho más es lo que niega.

Quinto ejemplo:

Vínculo desatado, instable puente.

La prora diligente (Sol. 2, vv. 48-49).

Insiste Góngora: desatar los vínculos, desestabilizar los puentes, pero sin faltar a la diligencia. Compárese con el siguiente juicio de Céan Bermúdez acerca de la pintura de borrones de Pedro Orrente: "Las pinturas de Orrente tienen mucha novedad y capricho. Como conocía bien el efecto, no se empeñaba en concluirlas, pero sin faltar a la exactitud del dibujo" 185 .

185 Juan Agustín Ceán Bermúdez, Diccionario histórico de los más ilustres profesores de las 
La exactitud del dibujo está en función de la inexactitud del efecto. La diligencia trabaja al servicio de la negatividad, de manera que la obra esté al mismo tiempo acabada e inacabada.

Sexto ejemplo:

$$
\begin{aligned}
& \text { Perdona si, desatado } \\
& \text { mi pobre espíritu en lenguas. } \\
& \text { (OC, I, núm. 282, vv. 93-94). }
\end{aligned}
$$

Insiste una vez más: una lengua desatada, como si la poesía fuera una Pentecostés. Perdona si mi pobre espíritu (con minúsculas) habla en lenguas como si acabara de visitarlo el Espíritu Santo (con mayúsculas).

Libre, confuso, amoroso y no viril, lo desatado abarcaría al menos cuatro campos semánticos: la lengua, el paisaje, el deseo y la identidad sexual. Volvamos ahora al retrato ecuestre:

La espumosa del Betis ligereza bebió no solo, mas la desatada majestad...

¿No solo bebió la espumosa ligereza del Betis o la espumosa del Betis ligereza bebió no solo? ¿Oratio vincta u oratio soluta? La una en el interior de la otra, sin separar nunca sentido y barullo, la cosa y la espuma. La majestad del sentido es inseparable de la espuma en que se disuelve ${ }^{186}$.

\section{LOS HUMORES: CABALLO, QUE COLÉRICO MORDÍA}

La pintura del caballo delata cierta familiaridad con la hipología de la época, como es de esperar en una cultura ecuestre donde el que más y el

Bellas Artes en España, ed. facsimilar con prólogo de Miguel Morán Turina, Madrid, Akal, 2001, III, letra OR, p. 276.

186 Ver al respecto Rafael Bonilla Cerezo, "El peregrino confuso (Góngora, Soledades, 1613, vv. 1-4)", Studia Aurea, 14 (2020), pp. 271-324, que sin llegar a decirlo con todas las palabras, apunta con claridad en la misma dirección. 
que menos era experto en la materia ${ }^{187}$, y donde el retrato de equinos en particular disfrutaba del mayor reconocimiento ("sólo el caballo les dará [a los pintores] renombre") ${ }^{188}$.

La primera lección tiene que ver con los humores. Al igual que las personas, los corceles podían ser sanguíneos, flemáticos, coléricos o melancólicos, cada uno con su pelaje (castaño, blanco, alazano y morcillo) y su elemento (aire, agua, fuego y tierra) correspondientes. Grisone lo explica así (fig. 11):

187 La descripción más completa de los tratados de hipología de la España de los siglos XVI y XVII, impresos y manuscritos, es la "Introducción" de José Antonio de Balenchanal en el Libro de la jineta y descendencia de los Guzmanes. Seguido de Pintura de un potro de Luis de Bañuelos y de la Cerda, Madrid, La Sociedad de Bibliófilos Españoles, 1877, pp. v-lxxi. Sobre la cultura ecuestre en los siglos XVI-XVII en general, ver Carlos José Hernando Sánchez, "El caballo y la corte. Cultura e imagen ecuestre en la monarquía de España (1500-1820)", en Mil años del caballo en el arte hispánico. Real Alcázar de Sevilla, 5 de abril -17 de junio de 2001, ed. Paloma Flórez Plaza, Madrid, Sociedad Estatal España Nuevo Milenio, 2001, pp. 107-145; Carlos José Hernando Sánchez, "La cultura ecuestre en la corte de Felipe II", en La monarquia de Felipe II: La casa del Rey, eds. José Martínez Millán y Santiago Fernández Conti, Madrid, Fundación Mapfre Tavera, 2005, I, pp. 226-292; y Raffaele Puddu, “Toros y cañas. Los juegos ecuestres en la España del Siglo de Oro", Revista de Estudios Taurinos, 24 (2008), pp. 13-49.

188 Pablo de Céspedes, Poema de la pintura o Zoográfica, en Escritos de Pablo de Céspedes, ed. Jesús Rubio Lapaz y Fernando Moreno Cuadro, Córdoba, Diputación de Córdoba, 1998, pp. 373-404 (p. 390). Como es sabido, Céspedes y Góngora eran íntimos amigos. Como pintor educado en Roma, estaba perfectamente familiarizado con la estética del borrón, que cita expresamente en su Discurso de la comparación de la antigua y moderna pintura y escultura (Córdoba, h. 1605): "Entiende [Plinio el Viejo] que es gran primor, como de verdad lo es, y artificio grande, las líneas que circunscriben una figura o miembro de ella estar de tal manera disimuladas, que no se vean los perfiles ni término alguno, sino que parezca que van arredondeando y que si Vuestra Merced [Pedro de Valencia, coleccionista de pinturas y uno de los primeros lectores de las Soledades] volviese la figura, hallaría la otra parte que no se ve. Porque en estando perfilada, ya se acaba alli la vista y corta aquella parte, y no promete más que aquello que tiene perfilado, y asi los buenos maestros huyen esta suerte de manera perfilada" (Pablo de Céspedes, op. cit., p. 264). La pintura es la promesa de una forma inacabada que se proyecta más allá de la vista. El Discurso ha sido reproducido asimismo en Jesús Rubio Lapaz, Pablo de Céspedes y su círculo. Humanismo y contrarreforma en la cultura andaluza del Renacimiento al Barroco, Granada, Universidad de Granada, 1993, pp. 419-440 (p. 425). 
Diré, pues, primeramente que la calidad del caballo procede de los cuatro elementos y con aquel elemento del cual más participa se conforma. Si toma más de la tierra que de los otros será melancónico terrero, pesado y vil, y suele ser de color morcillo o de ciervo melado o de ratón, que llamamos vellori ['pardo ceniciento'], o de semejante variedad de colores. Y si toma más del agua, será flemático tardío y blando, y suele ser blanco; y si toma más del aire, será sangüino, alegre, ágil y de templado movimiento, y suele ser castaño; y si toma más del fuego, será colérico, ligero fogoso y saltador, y pocas veces de mucho nervio; y suele ser alazano, semejante a la llama o al carbón encendido. Más cuando con la debida proporción participa de todos cuatro, entonces será perfecto ${ }^{189}$.

Algo parecido dice Pérez de Navarrete en el Arte de enfrenar:

Conviene al caballero entender que no es de menos importancia al argumento que se hace el color del caballo y la naturaleza de su boca, porque lo general es que las colores muestran la complexión; y así debe tener por cierto que el caballo alazán es colérico naturalmente, y es ardentísimo de boca. El blanco es flemático. El morcillo, melancólico. El bayo es sanguíneo ${ }^{190}$.

Góngora se decanta por el humor colérico: "Caballo, que colérico mordía" (Sol. 2, v. 816); aunque inmediatamente se corrige (sí, pero no) y añade: "Que colérico mordía / el oro que süave lo enfrenaba". Colérico, ma non troppo; cólera y suavidad.

A los caballos coléricos les corresponde el color alazano, el color tierra. Así, por ejemplo, en el retrato ecuestre de Felipe IV de Calderón, que sigue al pie de la letra los tratados de hipología: "Era un alazán tostado / de feroz naturaleza / el monarca irracional, / en cuyo color se muestra / la cólera" ${ }^{191}$.

189 Federico Grisone, Reglas de la caballería de la brida, trad. Antonio Flores de Benavides, Baeza, Juan Baptista de Montoya, 1568, lib. 1, f. 2v. Es traducción de Gli ordini di cavalcare (Nápoles, 1550), uno de los tratados de hipología más influyentes de la época.

190 Francisco Pérez de Navarrete, Arte de enfrenar, Madrid, Juan González, 1626, f. 3r.

191 Pedro Calderón de la Barca, La banda y la flor, ed. Jéssica Castro Rivas, Madrid, Iberoamericana, 2016, p. 199, Jornada I, vv. 449-453. El texto no puede ser más 
El caballo de las Soledades no es alazano, sino "cerúleo", color cielo. ¿Por qué?

\section{LOS COLORES: ESTRELLAS SU CERÚLEA PIEL AL DÍA}

La segunda lección tiene que ver con los colores: "De las [sic] colores de los caballos" (Aguilar) ${ }^{192}$; "Colores del caballo" (Vargas Machuca) ${ }^{193}$; "Que trata de las [sic] colores de los caballos" (López de Zamora) ${ }^{194}$.

Los colores naturales de los caballos son: overo (como en la segunda Soledad, vv. 678 y 732), castaño, morcillo, ruano, cebruno, cenizoso, rucio, peceño, blanco, rucio azul ("que es cuando tira a cárdeno") ${ }^{195}$, rucio ruano, rucio palpado, alazano, castaño peceńo, bayo (como en la Soledad segunda, vv. 678 y 732), argentado, tordillo y cebruno; y las combinaciones de éstos: mosqueado, picazo, zaonado, savino, nevado, golondrino, pel de rata y lobuno.

Góngora se decanta por "cerúleo" o 'blanquiazul' (color de "porcelana", anota Salcedo Coronel) ${ }^{196}$, que aparte de ser un cultismo pedantes-

distinto al de Góngora: "tan soberbio se miraba" (v. 457), "vivo Atlante de las fieras" (v. 462), "el desprecio y la fuerza" (v. 464), "quebrando las piedras" (v. 466), "en los estribos la fuerza" (v. 502), etc.

192 Pedro de Aguilar, "De las colores de los caballos", en Tratado de la caballería de la jineta, Sevilla, Hernando Díaz, 1572, primera parte, cap. 2, ff. 2r-3r.

193 Bernardo de Vargas Machuca, "Colores del caballo", en Teórica y ejercicios de la jineta, Madrid, Diego Flamenco, 1619, primera parte, cap. 1, ff. 3r-5r.

194 Pedro López de Zamora, "Que trata de las [sic] colores de los caballos", en Libro de albeitería (1571), Logroño, Mathias Mares, 1588, cap. 11, ff. 12v-14r.

195 Pedro Fernández de Andrada, "Del nombre que tiene cada color y los blancos [las manchas blancas] que ha de tener cada una de ellas", en De la naturaleza del caballo, Sevilla, Fernando Díaz, 1580: "El décimo color es rucio azul, que es cuando tira a cárdeno" (lib. 1, cap. 34, ff. 64r.-66r. [f. 65v.]). El libro incluye un retrato ecuestre del "gallardo joven" Felipe II que no por ser joven deja de exudar virilidad: "Caballo fiero", "al Macedonio admira”, "ase la rienda y con desdén mañoso / vuélvelo al sol”, "otro nuevo Alejandro", etc.

196 García de Salcedo Coronel, Soledades comentadas: "Este color que finge nuestro poeta en el caballo es el que llamamos porcelana" (f. 296v). Así también en el Diccionario de Autoridades: "Se llama también el color blanco, mezclado de azul" (op. cit., s. v. porcelana). 
co del que se burla Quevedo en el soneto que empieza "Sulquivagante, pretensor de Estolo" ("niños inquïetas [por pederasta], / parco, cerúleo, veterano vaso" $)^{197}$, no es un color equino. Ningún tratado de hipología trata sobre los caballos de pelaje "cerúleo" (aunque si estudian en detalle el valor de dicho color en la pintura, como veremos a continuación). Es un color literario con una larga tradición que pasa por Claudiano ("Claudiano lo describe de pelaje cerúleo") ${ }^{198}$, Opiano ("Opiano nos enseña en versos que los caballos de color cerúleo con pies calzados son buenos con los ciervos) ${ }^{199}$, Ovidio ("correrá Tritón / cos sus destreros cerúleos por el mar") ${ }^{200}$, y Estacio (“Claudiano llama a los caballos de Neptuno por epíteto verdes, y Estacio cerúleos los de Tetis, su consorte”) ${ }^{201}$, por citar algunas de las auctoritates infaltables de Góngora, y que contra el parecer normalmente acertado de Salcedo Coronel ("cerúleo es aquel color que imita al cielo cuando está más puro y desembarazado de nubes”) ${ }^{202}$, se refiere, bien al color del mar ("cerúleas ondas"203, "tórnase cana espuma el mar cerúleo") ${ }^{204}$, y específicamente a los caballos de Neptuno ("cerúlea para los de a caballo, porque éste es el color del mar, cuyo rey es Neptuno; en cuya

197 Quevedo, "Al mesmo Góngora", op. cit., núm. 836, vv. 11-12. Ver al respecto Dámaso Alonso, "Vocablos cultos de la Soledad Primera", en Obras completas. V. Góngora y el gongorismo, Madrid, Gredos, 1978, pp. 54-72 (p. 58); y la "Lista de palabras afectadas según censuras y parodias literarias del siglo XVII”, ibidem, pp. 102-116 (p. 105).

198 Pasquale o Pasqual Caracciolo, La gloria del cavallo, Venecia, Gabriel Giolito de' Ferrari, 1567: "Claudiano il discrive di pelo ceruleo" (lib. 2, p. 126). Ver al respecto Carlos José Hernándo Sánchez, "La gloria del cavallo. Saber ecuestre y cultura caballeresca en el reino de Nápoles durante el siglo XVI”, en En Felipe II (1527-1598). Europa y la monarquía católica. Actas del Congreso Internacional, Madrid, 20-23 abril 1998, ed. José Martínez Milán, Madrid, Parteluz, 1998, IV, pp. 277-310.

199 Pasquale Caracciolo, ibidem: "Oppiano c'insegna in versi che i cavalli di color ceruleo co' piedi varii e maculosi son buoni a' cervi” (lib. 4, p. 279).

200 Ibidem: "Correra Tritone / co' suoi destrier cerulei per lo mare" (lib. 1, p. 58).

201 Ibidem: "Claudiano chiama i cavalli di Nettuno per epiteto verdi, e Statio cerulei quelli di Tetide, sua consorte" (lib. 1, p. 58).

202 Salcedo Coronel, Soledades comentadas, ff. 296r-296v.

203 Espinosa, La fábula de Genil, en Poesía, p. 87, v. 53.

204 Espinosa, "A la navegación de San Raimundo", en ibidem, p. 110, v. 81. 
tutela estaba la caballería"205, "cerúleos caballos por los mares”) 206 , bien al color del cielo ("el otro pintó un rucio rodado, color de cielo", 207 "el país [paisaje] había de estar donde lo célico, por los horizontes”) ${ }^{208}$, sin nubes o con ellas ("una nube cerúlea"209, "cerúleos globos") 210 . Yo diría mejor con nubes, porque la forma informe de las nubes recuerda a "las manchas o las nubes de un bosquejo" 211 , "siendo los bosquejos en las tablas imitación de los arreboles en el aire. Porque viendo de una nube toscamente formadas

205 Sor Juana Inés de la Cruz, Inundación castálida, edición digital a partir de la de Madrid, Juan García Infanzón, 1689, y cotejada con la edición crítica de Georgina Sabat de Rivers, Madrid, Castalia, 1982, s. p. Disponible en la Biblioteca Virtual Miguel de Cervantes, www.cervantesvirtual.com.

206 Agustín de Tejada, El doctor Agustín de Tejada, a la embarcación del condestable, en María Dolores Martos Pérez, La obra poética de A. de Tejada: Estudio y edición, tesis doctoral, Málaga, Universidad de Málaga, 2008, XXXV, pp. 750-754, vv. 121-123. Me ha sido imposible consultar la versión impresa, Obras poéticas, eds. María Dolores Martos Pérez y José Lara Garrido, Sevilla, Fundación José Manuel Lara, 2011.

207 Mateo Alemán, Guzmán de Alfarache, ed. Francisco Rico, Barcelona, Planeta, 1983, primera parte, lib. 1, cap. 1, p. 108. Todo el pasaje, en el que se describe en detalle el retrato ecuestre "bien acabado", aunque "con admirables lejos, nubes, arreboles", de un "famoso pintor" imaginario, es de enorme interés. Lo cita Luis Gómez Canseco, "Ut poesis pictura. Relatos pictóricos para la ficción en Mateo Alemán (y en Cervantes)", en Ficciones de la ficción. Poéticas de la narración inserta (siglos XV-XVIII), ed. Valentín Núnez Rivera, Barcelona, Universitat Autònoma de Barcelona, 2013, pp. 167-180.

208 Juan Izquierdo de Piña, Casos prodigiosos y cueva encantada (1628), ed. Emilio Cotarelo y Mori, Madrid, Librería de la Viuda de Rico, 1907, p. 263. Se trata de la écfrasis detallada del Retrato ecuestre de Felipe IV de Rubens, "cuyos valientes golpes y líneas sutiles admiran y enmudecen" (p. 263). Apud Javier Portús Pérez, "La recepción en España del 'arte nuevo' de Rubens", en Arte y diplomacia de la monarquía hispánica en el siglo XVII, ed. José Luis Colomer, Madrid, Fernando Villaverde, 2003, pp. 457-471 (pp. 467-468).

209 Virgilio, op. cit:: "Cual la nube cerúlea [qualis cum caerula nubes]" (lib. 8, v. 622).

210 Conde de Villamediana, Fábula de Faetón, en Poesía impresa completa, ed. José Francisco Ruiz Casanova, Madrid, Cátedra, 1990: "Volando entre nubes animoso, I quedó en cerúleos globos sepultado” (VIII, vv. 1723-1724). Hay edición algo mejor a cargo de Lidia Gutiérrez Arranz, Las fábulas mitológicas, Kassel, Reichenberger, 1999.

211 Bartolomé Leonardo de Argensola, "A Nuño de Mendoza, que después fue conde de Val de Reyes": "Y el dedo (ya pincel) curte el pellejo, / donde extiende con líquidos barnices / las manchas o las nubes de un bosquejo" (op. cit., t. 1, 45, p. 104, vv. 316-318). 
un elefante, un castillo y una ciudad, llegó a hacer misterio la atención y a hallar originales el dibujo" 212 . Tómese casi cualquier cuadro del Greco y se comprobará al instante: salvo el color, apenas hay diferencia entre las nubes, las rocas y los paños; todo el cuadro es la mancha o la nube de un bosquejo (Fig. 12) ${ }^{213}$.

Si el retrato aludiese al conde de Niebla, el color cerúleo podría referirse al fondo azul de su escudo de armas, como subraya Espinosa en el poema "A la color azul suya", incluido en el Elogio al retrato: "El cielo por ser del Duque [el VIII duque de Medina Sidonia], / y el Duque por ser del cielo"214. Más aún, cinco de los caballos que el conde le regaló al príncipe de Gales durante la estancia de éste en Madrid eran —dice Espinosa- "cerúleos", a saber: Guzmán, como el propio conde de Niebla ("piel azul”) ${ }^{215}$; El Africano (“cerúleo claro") ${ }^{216}$, Torbellino (“azul subido”) ${ }^{217}$, Pie de Plata ("piel que parece azul y es cielo sembrado de estrellas") ${ }^{218}$ y El Pavón ("cerúleo subido") ${ }^{219}$. Pero nótese de nuevo que la descripción de Pie de Plata ("piel que parece azul y es cielo sembrado de estrellas")

212 Juan Rodríguez de León, El predicador de las gentes, San Pablo, Madrid, María de Quiñones, 1638, lib. 1, cap. 34, ff. 70v-71r. El texto difiere ligeramente del Parecer del doctor Juan Rodríguez de León, insigne predicador de esta corte recogido en el $\mathrm{Me}$ morial informatorio (1629) y editado recientemente por Antonio Sánchez Jiménez y Adrián J. Sáez, Siete memoriales españoles en defensa del arte de la pintura, Madrid, Iberoamericana, 2018, pp. 95-112.

213 El estudio clásico es el de Hubert Damisch, Théorie du nuage. Pour une histoire de la peinture, París, Seuil, 1972, con numerosas referencias al Greco, Santa Teresa y Zurbarán, como no podía ser menos. Sobre el mismo tema, ver también Erwin Panofsky, "Nebulae in Pariete'. Notes on Erasmus' Eulogy on Dürer", Journal of the Warburg and Courtauld Institutes, 14, 1/2 (1951), pp. 34-41; y Ernst Hans Josef Gombrich, "The Image in the Clouds" (1960), en Art and Illusion, Princeton, Princeton University Press, 2000, pp. 181-202. En términos generales, las nubes representan la falta de forma.

214 Espinosa, Obras, pp. 112-113; y Poesía, op. cit., pp. 285- 286, vv. 9-10. No figura en la edición de López de Estrada "por hallarse fuera del contexto de la prosa" (p. 322, n. 226).

215 Espinosa, Obras en prosa, p. 301.

216 Ibidem, p. 302.

217 Ibidem, p. 303.

218 Ibidem, p. 303.

219 Ibidem, p. 304 
es un plagio del caballo de las Soledades ("estrellas su cerúlea piel al día"). ¿Quién copia a quién? ¿Espinosa a Góngora o Góngora al conde de Niebla? Todo indica que Espinosa a Góngora.

Además, cerúleo no es sólo un color literario. Es también un color pictórico cuyo significado desgrana Caracciolo en La gloria del caballo (Fig. 13), la summa del saber equino de su tiempo. El pasaje — toda una teoría del color que no tiene nada que envidiarle a El libro del arte de Cennino Cennini o a la Idea del templo de la pintura de Lomazzo- empieza:

Es de notar que algún color es propio, alguno impropio. Impropias son aquellas luces que representan los colores; propias, aquéllas que siguen los elementos o sus mezclas; y de éstos mismos algunos son verdaderos [veri], que acompañan los cuerpos mezclados, algunos falsos [falsi], aunque tienen verdaderas imágenes, y otros que se llaman inciertos [incerti], que engañan los ojos de los espectadores, como el resplandor del cielo [lo splendore del cielo], como las nubes [nuvole] y como las aguas del mar [l'acque del mare], el cual, además de cerúleo [ceruleo], ahora parece verde, ahora flavo ['de color entre amarillo y rojo, como el de la miel o el del oro'] y ahora purpúreo [cursivas en el original] ${ }^{220}$.

\section{Y añade a continuación:}

Esta incertidumbre de colores [incertezza di colori] la vemos adornar especialmente el pescuezo de las palomas o del pavo real; y así suelen llamarse aves multicolores [versicolori], como también es una suerte de seda $[$ seta] que parece de diversos colores; la cual variedad es difícilísima y casi imposible de expresarse por los pintores [la qual varietà è diffcilissima e quasi impossibile ad esprimersi da' pittori $]^{221}$.

220 Caracciolo, op. cit., lib. 4, p. 255: "E da notarsi alcun colore esser proprio, alcuno improprio. Impropri sono quelli lumi che rappresentano i colori; propri quelli che seguono gli elementi o i loro misti; e di essi propri alcuni son veri, che accompagnano i corpi misti, alcuni falsi, ma che hanno di veri immagine, i quali si dicono incerti, che ingannano gli occhi de' riguardanti, come lo splendore del cielo, come le nuvole et come l'acque del mare, il quale oltra il ceruleo, hor appare verde, hor flavo \& hor purpureo".

221 Ibidem, lib. 4, p. 255: "Questa incertezza di colori si vede grandemente adornare il collo della colomba e del pavone; e però tali augelli versicolori si sogliono dire, come 
Los colores pueden ser impropios o propios, y éstos, verdaderos, falsos o inciertos (ni verdaderos ni falsos). Cerúleo, el tinte del mar y de las nubes, es un color propio de tipo incierto cuyos variados matices, parecidos al collar de las palomas, el plumaje de los pavos reales y el brillo tornasolado de la seda, engañan los ojos, por lo cual resulta dificilísimo, casi “imposible" de pintar.

¿Por qué un caballo "cerúleo", en vez de morcillo ("sale Tisandro en un frisón armado, / que apenas con el freno le sujeta, / morcillo de color, de crin poblado") 222 , negro ("en un caballo negro Sancho el Bravo, de un jaco armado con la banda roja”) ${ }^{223}$, rosillo ("un rosillo de España mal seguro / castiga en sangre y en sudor bañado")224, alazano ("dos fuertes alazanes, I con mil victorias de los moros fieros" ${ }^{225}$ o de cualquier otro color, cuando "cerúleo" ni siquiera es el color natural de un caballo? Se me ocurren al menos dos razones.

La primera, de tipo estético: son caballos "hermosos", "galanes" y "vistosos", si bien débiles. En efecto, tal y como advierte Luis de Zapata en el Libro de cetrería: "El buen rocín de caza ha de ser duro. / [...] / De que sea muy hermoso no me empacho. / Overo y blanco tache, y más quiero uno / o rosillo, o cebruno, o avutardo, / o alazán tostado a de otra suerte / que el galán"226. Otro tanto opinan Vargas Machuca: "El blanco, además de ser enfadoso por lo que ensucia con los pelos, no lo apruebo por bueno a causa de la poca fortaleza, aunque es galán, ligero y de razonable boca"227; y el autor anónimo de la Pintura de un potro: "Los rucios son muy valientes y de bondad, y mejores los rodados. Dejo aparte los tordillos azules, marmoleños ['color de mármol'] y milados rucios ['pardo claro'], sucios porcelanas, blancos de piel encarnada, que aunque son vistosos, no son para

anco è una sorte di seta che con diversi colori appare; la qual varietà è difficilissima $\&$ quasi impossibile ad esprimersi da’ pittori”.

222 Lope de Vega y Carpio, Jerusalén conquistada, lib. 10, p. 416, estrofa 134.

223 Ibidem, lib. 13, p. 545, estrofa 154.

224 Ibidem, lib. 13, p. 508, estrofa 8.

225 Ibidem, lib. 13, p. 546, estrofa 156.

226 Luis de Zapata, "De rocines de caza", en el Libro de cetrería. Cito por la tesis doctor-

al inédita de Irene Rodríguez Cachón, El Libro de cetrería (1583) de Luis de Zapata: estudio y edición crítica, Valladolid, Universidad de Valladolid, 2013, cap. 153, pp. 328-330 (p. 328, vv. 8293-8300).

227 Vargas Machuca, op. cit., f. 4v. 
tanto como los demás, y son de estima por haber pocos"228. Bello y raro, sí; fuerte, para nada. Un príncipe no robusto en un caballo no robusto. "Perdonando / poco a lo fuerte — dice Góngora-, y a lo bello nada" (Sol. 2, vv. 707-708). La belleza siempre le lleva la ventaja a la fortaleza.

La segunda, de tipo epistemológico: el color cerúleo no es ni verdadero ni falso, sino radicalmente "incierto", como los "inciertos mares" (Sol. 1, v. 499), "los inciertos de su edad segunda / crepúsculos" (Sol. 1, vv. 775776) y la "incierta ribera" (Sol. 2, v. 27), entre otros ejemplos; sin olvidar los "metros inciertos" (Sol. 2, v. 356) de las propias Soledades. El poema canta, en metros inciertos - la silva-, un objeto incierto de color incierto. Estética del matiz, por un lado ("o por lo matizado o por lo bello"229, "sea bien matizada la librea"230, "la variedad matiza del plumaje") ${ }^{231}$; y por el otro, la metafísica figurada de Barbaro, "una ternura en el horizonte de nuestra vista que es y no es". Incierto: es y no es, dice y no dice, se entiende y no se entiende. "Son los retratos más ciertos / cuan inciertos los colores" ${ }^{\prime 232}$.

228 Anónimo, Pintura de un potro, por donde se conocerá en las hechuras, la fuerza y señales y pruebas que de él se hicieren la hermosura y bondades que ha de tener, en Luis de Bañuelos y de la Cerda, op. cit., pp. 1-91 (p. 10).

229 Góngora, Sol. 1, v. 249.

230 Góngora, "Burlándose de un caballero prevenido para unas fiestas", $O C$, I, núm. 113 , v. 1. Nótese que se trata de un retrato ecuestre burlesco.

231 Góngora, "A Luis de Cabrera, para la Historia del señor rey don Filipo el Segundo": "La variedad matiza del plumaje / el color de los cielos turquesado" (OC, I, núm. 272, vv. 20-21). Matiz y paisajes azules a la vez. Sobre la voz matiz, ver Eleanor Webster Bulatkin, "The Spanish Word 'Matiz': Its Origin and Semantic Evolution in the Technical Vocabulary of Medieval Painters", Traditio, 10 (1954), pp. 459527: "Mármol manchado o matizado menudo" (p. 464); "por extensión vale manchar con algún color alguna cosa a trechos salpicándolo" (p. 465). Manuel de Faria e Sousa es aún más agudo: "El deseo en el matiz procede / y de la misma confusión se vale". El deseo no pinta, sino que mancha. Ver su "Retrato de Albania", en Fuente de Aganipe o Rimas varias. Parte segunda, Madrid, Juan Sánchez, 1643, f. 114r, estrofa 61. El libro está dedicado al autor de El arte de la pintura —Francisco Pacheco-y revela un profundo conocimiento de la teoría pictórica del momento.

232 Juan de Ávila, "Pondéranse los primores del retrato que en tres dobleces de su lienzo sacó la mujer Verónica", en Pasión del Hombre-Dios, Lyon, Horace Boissat y George Remeus, 1661, canto II, pp. 23-26 (p. 25). 


\section{LAS SEÑAS: ESTRELLAS SU CERÚLEA PIEL AL DÍA}

La tercera lección tiene que ver con las manchas: "Juicios de los caballos a partir de la observación de las estrellas" (Caracciolo) ${ }^{233}$; “De los blancos y lunares de los caballos" (Caracciolo) ${ }^{234}$; “De las señales particulares y otras calidades que los caballos tienen, en la boca y en otras partes, y de cómo conviene el conocimiento de él para el remedio de su enfrenamiento" (Aguilar) ${ }^{235}$.

En los siglos XVI y XVII, la piel de un caballo era un texto sembrado de señas que sólo los más "prácticos" o experimentados sabían descifrar: motas, listas ("la lista blanca no ha de llegar a las cejas"), listas salteadas, remolinos ("de los remolinos de los caballos, así de los que denotan bien como de los que denotan mal"), "pelos blancos por el cuerpo", "sin ningún blanco", caballos calzados de la mano izquierda, calzados de ambas manos, "calzados del pie de cabalgar", "calzados de todos cuatro pies y manos"... La naturaleza emite señas, y todas las señas significan algo. Más aún, dice Góngora, "cuyo cuerpo aun no formado / nos promete en sus señales / más" (OC, I, núm. 62, vv. 77-79). La seña es una promesa de sentido. Las seńas de los cuerpos todavía no formados prometen, y prometen más que si esos mismos cuerpos estuvieran formados.

"Estrella" es una metáfora lexicalizada que significa las manchas en la frente de un caballo ${ }^{236}$, y que denotaba, si se hallaba en la parte alta de la frente, sin tocar los ojos ni el hocico, bondad y perfección. Fernández de Andrada da el hecho por sabido (Fig. 14):

Estos lunares prietos o blancos que nacen a los caballos dicen muchos autores que deben ser en la parte trasera, porque allí son espuelas que les aguijan la voluntad, salvo aquéllos que vulgarmente llamamos estrellas, porque nacen en la frente; y éstos, demás que

233 Caracciolo, "Tavola prima delle cose notabili contenute nella presente opera”, $o p$. cit.: "Giudity dei cavalli dalla osservation delle stelle" (s. p.). El lib. 4, pp. 294-301, ofrece decenas de ejemplos.

234 Ibidem, lib. 4, pp. 280-295 y passim.

235 Aguilar, op. cit., cap. 9, f. 10r.

236 Ver nada más la definición de estrella del Diccionario de Autoridades: "Por semejanza [con el astro] se llama la mancha blanca que saca el caballo en la frente, y así se dice: 'Caballo con estrella o estrellado'”. 
alegran la vista del caballo, templan con su bondad la malicia de algunas señales que son reprobadas y tenidas por viciosas; y dicen los prácticos ['experimentados'] que si el caballo tuviere la estrella de la frente alta, que traerá el rostro alto y bien puesto, y si estuviere baja, traerá el rostro caído ${ }^{237}$.

Lo mismo dice Aguilar en su Tratado de la caballería de la jineta: "Los caballos que tuvieren blanco, en las partes de abajo, que denotan buena señal, si tuvieren juntamente con la estrella la lista que les descienda por la cara, sin tocarles a los ojos ni al hocico, serán perfectos y de gran bondad" 238 . En cambio, "los caballos que tuvieren estrella blanca en la frente, que no descienda con lista hacia abajo, y tuvieren otra sobre el rostro, serán desdichados y de mala boca"239.

$\mathrm{Al}$ ser estrella una metáfora vulgar, lexicalizada, Góngora se ve obligado a deslexicalizarla, y para ello convierte las estrellas-mancha en estrellas reales, pero diurnas: "Daba / estrellas su cerúlea piel al día"; 'su frente manchada de blanco (aunque en realidad todo el caballo era blanco) le daba estrellas al día'; o, más exactamente, 'su pelaje manchado de nubes como el cielo le daba estrellas nocturnas al día, no a la noche'. De este modo no sólo conseguía deslexicalizar la metáfora, sino introducir la idea de una luz negra, como el "nocturno día" (Sol. 1, v. 76) o el "nocturno Faetón" (Sol. 1, v. 655) de la primera Soledad. "Aun a pesar de las tinieblas bella, / aun a pesar de las estrellas clara", leemos en otra parte del poema (Sol. 1, vv. 71-72). Es un motivo recurrente en Góngora —el objeto resplandece en el interior de la oscuridad, sin renunciar a la luz, pero tampoco a la noche-que hallamos también en el epitafio al Greco, vinculado esta vez a las sombras de Morfeo: "Febo luces, si no sombras Morfeo" (OC, I, núm. 269, v. 11). Con ello quería decir lo que numerosos críticos de arte han confirmado trescientos años después, a saber, que los mejores cuadros del Greco - la última Adoración de los pastores (1612-14), la Vista de Toledo (1595-1600), La Visión de San Juan (1608-14), Lacoonte (1608-14), etc. - tienen un aire espectral, como si sus figuras emergieran del sueño.

237 Fernández de Andrada, "De los blancos y lunares de los caballos”, lib. 1, cap. 32, ff. $56 \mathrm{r}-59 \mathrm{v}$ (f. 56v).

238 Aguilar, op. cit., primera parte, cap. 3, f. $4 \mathrm{r}$.

239 Ibidem, primera parte, cap. 3, f. $4 \mathrm{v}$. 
Ya en su edición anotada de Vitruvio, Barbaro se refería a la pintura de grutescos como "sogni della pittura" o 'sueños de la pintura'240. Pero la mejor explicación que conozco al respecto es la que ofrece Catherinot en su olvidado Traité de la peinture (1697): "El gran maestro de los pintores es Morfeo, de donde viene su nombre. Porque forma viene de morpha, trasponiendo las letras" ${ }^{241}$. Y todavía se atreve a añadir: "Soñar es pintar a

240 Barbaro, op. cit., lib. 7, cap. 5, p. 188, líneas 28-29: “Los grotescos, los cuales sin duda podemos llamar sueños de la pintura [le grottesche, lequali senza dubbio potemo nominare sogni della pittura]". Los subrayados son del Greco. Por su parte, Armenini sitúa el origen de la pintura de grutescos en las manchas (macchie) que se ven en los muros. Ver al respecto Armenini, op. cit., lib. 3, cap. 12, p. 247: "Como cosas vistas por casualidad [caso], que es el efecto que producen los grutescos o quimeras a los que nos referimos. Así pues se cree que tuvieron su origen en esos emplastes o manchas [toppe over macchie, 'parches o manchas'] que se descubren sobre aquellos muros, que entonces eran totalmente blancos cuando, observando atentamente [sottilmente, 'con sutileza'] esas manchas [macchie], se representan diversas fantasías [fantasie] y formas novedosas de cosas extravagantes [nuove forme di cose estravaganti]". Sobre la relación entre la pintura y el sueño, ver Félix de Lucio Espinosa, "Símbolo de los sueńos fue el capricho de un pintor célebre”, en Ocios morales, Mazzarino, Sicilia, Juan Vanberge, 1691, pp. 26-29: "Aquel contorno que antes daba proporción al cuerpo, ahora sirve de cuerpo que abulte más el borrón de las imperfecciones" (p. 27). El contorno que antes garantizaba la proporción de los cuerpos encerrándolos dentro del límite de la forma ahora se convierte en un borrón que destruye esa misma proporción reduciendo los cuerpos a un bulto. Por "sueño" Espinosa y Malo entiende distintas cosas, cada cual más sorprendente: "Una dislocación enredosa de discursos" (p. 28), "fragmentos de la casualidad" (p. 24), "asuntos ridículos del Bosco" (p. 25), "pardos [oscuros] dibujos del genio" (p. 25), "juicio sin juicio" (p. 25), "consecuencia sin hilaciones" (p. 25), "casuales reflexiones del genio" (p. 25), etc. Sobre las ideas artísticas de Espinosa y Malo, ver Ángel Aterido, “Textos artísticos de Félix de Lucio Espinosa y Malo: 'De la pintura y algunos inventores y preceptos della", en "Sacar de la sombra lumbre": La teoría de la pintura en el Siglo de Oro (1560-1724), ed. José Riello, Madrid, Akal, 2012, pp. 149-171.

241 Nicolas Catherinot, Traité de la peinture, Bourges, 1697, p. 2: "La pintura reina en todas partes, en las conchas, en los peñascos, en los muros sucios, en las nubes e incluso en el corazón de ciertos árboles y en sus lobanillos. Pero el gran maestro de los pintores es Morfeo, de donde viene su nombre. Porque forma viene de morpha, trasponiendo las letras [La peinture règne par tout, dans les coquilles, les rochers, les parois sales, les nuages et même dans le coeurs de certains arbres et dans leur loupes. Mais le grand maitre des peintres, c'est Morphée et il an tire son nom. Car forma vient de morpha, en transposant les lettres]". Un tratado rebosante de ingenio que bien merece ser reeditado. 
ojos cerrados y a tientas [songer c'est peintre à veuë close et à tastons]"242. La forma es un sueño entrevisto; "rigor y sueño" ${ }^{243}$. El pintor no sabe lo que pinta sino que lo busca con el pincel, en una especie de sueño despierto que conjuga las luces de Febo con las sombras de Morfeo. La explicación del propio Greco concuerda con la de Góngora: "La perfección del día es la noche" ${ }^{244}$. Es decir, la perfección del objeto coincide con su elisión en el horizonte de la mirada. El objeto resplandece donde no acaba de verse. La formulación de Paravicino sería: “Divino don, como ponderó el Crisólogo [san Pedro Crisólogo], extraño modo de luz, como los teólogos notan, ver en la confusión la evidencia, en las tinieblas la claridad" ${ }^{245}$. La evidencia no reside en lo evidente, sino en la confusión; donde el objeto se pierde para la vista, sólo allí lo recobra la atención ${ }^{246}$.

242 Ibidem, p. 2. Sobre la ceguera del pintor, ver Jacques Derrida, Mémoires d'aveugle: L'autoportrait et autres ruines, París, Réunion des musées nationaux, 1990: "He aquí una primera hipótesis: El dibujo es ciego [aveugle], si no el dibujante o la dibujante. Como tal y en su momento propio, la operación del dibujo tendría algo que ver [quelche chose à voir] con la ceguera [aveuglement]" (p. 10). Quiere decir, como explica Catherinot, que pintar es soñar con los ojos abiertos, un tanteo a ciegas por sucesión aproximativa. En la misma dirección, ver Jean-François Lyotard, Sam Francis: Leçon de Ténèbres, "Like the Paintings of a Blind Man", ed. Herman Parret, Lovaina, Leuven UP, 2010. Aunque la etimología de forma es incierta, es seguro que no tiene nada que ver con Morfeo. El anagrama de Catherinot sólo demuestra el deseo del Barroco de separar la noción de "forma" de la idea de "límite", incluso de la idea de "razón", y fundar su origen en el sueńo. La etimología es falsa, no el razonamiento.

243 Paul Valéry, Cahiers: "Rigueur et reverie / Art polygonal des Arabes [Rigor y sueño / Arte poligonal de los árabes]” (t. 2, p. 977). No figura en la selección de los Cuadernos de Sánchez Robayna. "Mientras perdona tu rigor al sueño" (Sol. 2, v. 676), dice Góngora.

244 El Greco, "Las notas marginales", en Las ideas artísticas de El Greco, p. 230.

245 Fray Hortensio Paravicino, Sermones cortesanos, ed. Francis Cerdan, Madrid, Castalia, 1994, p. 323. En el mismo sermón: "Manchen, digo, aunque diga rayos de luz" (p. 300); "lo encendido de la claridad más hermosa, mancha viene a ser" (p. 300); "de esta copia borrada, si no al brochón, a un pincel poco menos tosco" (p. 300). Las referencias a la pintura de borrones son constantes.

246 “Donde os perdía mi vista, / os cobraba mi atención!” (Góngora, OC, I, núm. 383, vv. 27-28). Una vez más, el interés del objeto radica en su negatividad. La presencia positiva del objeto dice menos que su "pérdida", sin que dicha pérdida puede reducirse de ninguna manera a la simple ausencia. 


\section{El ENFRENAMIENTO: EL ORO QUE SÜAVE LO ENFRENABA}

La cuarta lección de hipología tiene que ver con el enfrenamiento. Los manuales insisten: "frenos y sus efectos y calidad" (Caracciolo) ${ }^{247}$; "reglas para enfrenar y doctrinar caballos" (Grisone) ${ }^{248}$; "de los frenos y de los nombres y deficiencias que tienen, y de cómo se ha de usar de ellos" (Aguilar) ${ }^{249}$. En España, los dos tratados más duchos en la materia son el Libro de enfrenamientos de la jineta (1570 y 1583) de Eugenio Manzanas (Fig. 15) ${ }^{250}$ y el Arte de enfrenar (1626) de Pérez de Navarrete, ambos ilustrados con "abundantes y curiosas láminas de frenos" (Fig. 16) 251.

La parte más importante del "adoctrinamiento" de un caballo, como se decía en la época (adoctrinar un caballo es inculcarle ciertas ideas y erradicar otras), es el enfrenamiento. Sin el freno, no hay gobierno, y sin gobierno, prácticamente no hay caballo: "Si el caballo es provechoso para tantas cosas, forzado se hace confesar que lo es mediante el freno, sin el cual no hay gobierno. De suerte que se ha de estimar no menos el freno que el caballo, pues es el gobierno dél" 252 . El Estado también es un caballo y exige el mismo tipo de "adoctrinamiento": "La parte de animal que está en el hombre es inobediente a la razón, y solamente se corrige con el temor. Por lo cual es conveniente que el príncipe dome a los súbditos como se doma un potro" ${ }^{253}$.

Hay dos clases básicas de freno: uno áspero y otro suave. "Los frenos suaves [leios] — dice Jenofonte— son más adecuados que los ásperos

247 Caracciolo, "Tavola prima delle cose notabili contenute nella presente opera": "Freni e loro effetti e qualitá”, sin paginar. El índice remite al lib. 5, pp. 346 y ss., que tratan extensamente sobre los distintos tipos de freno.

248 Grisone, op. cit., f. 1 r.

249 Aguilar, op. cit., primera parte, cap. 8, ff. 8v-10r; f. 8v.

250 Eugenio Manzanas, Libro de enfrenamientos de la jineta, Toledo, Juan Rodríguez, $1583^{2}$.

251 Bañuelos y de la Cerda, op. cit., p. xiii.

252 Eugenio Manzanas, "Prueba de la estimación del freno y la hermosura y gentileza del caballo bien enfrenado", en op. cit., primera parte, cap. 1, ff. 2r-3r (f. 2v).

253 Diego Saavedra Fajardo, Empresas políticas, ed. Sagrario López Poza, Madrid, Cátedra, 1999, empresa 38, p. 491. Sobre el caballo como metáfora del Estado, ver Pierangelo Schiera, "Socialità e disciplina: La metafora del cavallo nei trattati rinascimentali e barocchi di arte equestre", en Il potere delle immagini. La metafora politica in prospettiva storica, eds. Francesca Rigotti, Pierangelo Schiera y Walter Euchner, Bolonia, Il Mulino, 1993, pp. 143-82. 
[trakheon]. Si se coloca uno áspero [trakhus], hay que asemejarlo al suave [leioi] dejándolo flojo"254. La traducción del siglo XVI de Diego Gracián es mejor que la actual: "Los frenos blandos son mejores que los ásperos, y si acaso fueren ásperos, deben aflojarles la barbada para que sean blandos y muelles" 255 .

No conformes con las indicaciones esquemáticas de Jenofonte, los tratados de hipología del siglo XVI - De la naturaleza del caballo de Fernández de Andrada ${ }^{256}$, las Reglas de la caballería de la brida de Grisone ${ }^{257}$, el Tratado de la caballería de la jineta de Aguilar ${ }^{258}$, etc.- multiplican los tipos de freno, dependiendo de las diferencias de boca del animal: freno de cañón, escacha, bastoncillo, pero, pero doble, melón con sortijuela, melón con dos sortijuelas, "campanello con el tempaño enarcado", "escacha con un botón engastado en cada parte que fácilmente se pueda rodear"... ${ }^{259}$. De todas maneras, la distinción básica de Jenofonte se mantiene en pie a lo largo de los siglos: "Frenos blandos [molli] y frenos rígidos [rigidi], ¿cuál freno?" 260 . Caballo de boca dura, freno duro: "Conviene que el freno sea recio y asiente sobre las encías, porque, como dice Ovidio, el áspero caballo con el duro freno se castiga la boca y obedece a su señor, y casi lo mismo dice Virgilio, que el caballo de boca dura con freno duro obedece y se sujeta"261. En cambio, si el caballo fuese blando de boca, es necesario emplear un freno suave que no le apriete demasiado la lengua ni le haga sangrar las encías: "Si el caballo mostrare una poca dureza de boca, le pondrás la escacha. Si no tuviese gran boca y fuese

254 Jenofonte, De la equitación, en Obras menores, ed. y trad. Orlando Guntiñas Tunón, Madrid, Gredos, 2008, p. 234, 9. Lo citan decenas de tratadistas y escritores.

255 Jenofonte, Las obras de Xenophon, trad. Diego Gracián, Salamanca, Juan de Junta, 1552, tercera parte, f. 193r. El texto se titula Hipparchico o Del oficio del capitán general de los de caballo.

256 Fernández de Andrada, "De los caballos duros de boca y de su remedio", lib. 2, cap. 12 , ff. $94 \mathrm{r}-96 \mathrm{v}$ (f. 95r).

257 Grisone, op. cit., lib. 4, ff. 112r-112v.

258 Aguilar, op. cit., cuarta parte, f. 85r.

259 Grisone, op. cit., ff. 121r-144v.; Manzanas, "Que trata de las diferencias de frenos", tercera parte, ff. 28v-38v; y Caracciolo, op. cit., lib. 5, pp. 350-361.

260 Caracciolo, "Tavola prima delle cose notabili contenute nella presente opera": "Freni molli e freni rigidi, qual freno" (s. p.).

261 Fernández de Andrada, op. cit., lib. 2, cap. 12, f. 95r. 
delicada y buena, además de estos frenos se le podría poner un melón liso a modo de aceituna, y sólo con la siciliana encima"262. Para enfrenar bastan dos géneros de frenos: "el uno freno abierto para boca mal formada y dura, y el otro freno cerrado para boca bien formada y blanda"263. Hecha esta salvedad, todos los autores insisten: "No se enmienda al potro mudándole diversidad de frenos ásperos, sino con la buena dotrina y con frenos blandos"264; "con el buen arte y verdadera doctrina, y con freno apacible en el cual templadamente se pueda afirmar y asegurar la boca"265; "traerle la mano suave y blanda"266; "todo lo que aquí se enseña se reduce a que se use de blandura y frenos suaves, y no de castigo"267.

Por razones puramente propagandísticas que no tienen nada que ver con el manejo real de un caballo - me refiero al mito del robusto paladín que sale a subyugar las fieras y aplastar a los moros subido a un alazano colérico-, prácticamente todos los poetas que describen un corcel fingen desconocer el axioma más elemental de la hipología ("no hay caballo desbocado, sino mal enfrenado" ${ }^{268}$ y pintan siempre un freno duro, como si la manera más eficaz de gobernar al animal fuera mediante la fuerza y la violencia y no, como enseñan todos los tratados de la época, mediante el amor ("enfrenar con amor y no con soberbia") ${ }^{269}$, el gusto y blandura ("por la mayor parte, suele hacer más efecto y causa el gusto y blandura que traen en la boca, que la fuerza y violencia que en ella se les pusiere") $)^{270}$, y la simple costumbre ("el freno puesto / no le sea molesto, antes suave; / la costumbre lo grave lo aliviana") ${ }^{271}$. Es "la ley del hierro en el freno" de Juan Mateos ("acostúmbranse al manejo del caballo, hacienda que su co-

262 Grisone, op. cit., lib. 3, f. 65r.

263 Pedro Fernández de Andrada, Nuevos discursos de la jineta de España, Sevilla, Alonso Rodríguez Gamarra, 1616, sección 8, ff. 14v-18r (f. 17r).

264 Grisone, op. cit., lib. 2, f. 61 r.

265 Ibidem, lib. 2, f. 61v.

266 Pérez de Navarrete, op. cit., f. 2v.

267 Bańuelos y de la Cerda, op. cit., p. 30.

268 Manzanas, "Prueba que no hay caballo desbocado, sino mal enfrenado", primera parte, cap. 2, ff. 3r-5v (f. 5v).

269 López de Zamora, "En el cual se trata de cómo se han de concertar en carrera y boca los caballos", cap. 6, ff. 9r-10v (f. 9r).

270 Aguilar, $o p$. cit., cuarta parte, f. 85 r.

271 Zapata, op. cit., p. 285, vv. 8271-8273. 
raje obedezca la ley del hierro en el freno; enséñase el brazo a vibrar lanzas; a ensangrentar puñales") ${ }^{272}$, que repiten autores como Agustín de Tejada en su "Al rey don Felipe [III], nuestro señor", publicado en las mismas Flores de poetas (1605) donde aparecieron treinta y cuatro composiciones de Góngora: "Mida el caballo con herradas manos / lo que hay desde la cincha hasta el suelo, / y argente con espuma el freno duro" ${ }^{273}$; Baltasar de Escobar en el soneto que empieza "El suelto brío del caballo fiero": "La boca rinde y toma / teme el duro freno" ${ }^{274}$; y Bernardo de Balbuena en El Bernardo: "Picó el caballo, a quien el duro freno / apartarle del miedo no podía" 275 . Pablo de Céspedes elogia "los sangrientos frenos y bozales" de los caballos de "pechos varoniles" ${ }^{276}$; y Lope de Vega "un freno / con que le oprime y desvía" ${ }^{277}$. El retrato ecuestre de Felipe IV de Calderón es programático: "Con tanto imperio en lo bruto / como en lo racional,

272 Mateos, "Al lector", op. cit., s. p.

273 Agustín de Tejada, "Al rey don Felipe, nuestro señor", en Pedro Espinosa, Primera parte de Flores de poetas ilustres de España, eds. Inoria Pepe Sarno y José-María Reyes Cano, Madrid, Cátedra, 2006, 15, pp. 218-225 (p. 218, vv. 18-20). El texto continúa: "Y guarnezca el bruñido doble velo / los pechos osadísimos hispanos, / de la misma fiereza recio muro" (vv. 21-23). La diferencia con respecto a Góngora no puede ser mayor.

274 Baltasar de Escobar, "El suelto brío del caballo fiero", en Pedro Fernández de Andrada, De la naturaleza del caballo, s. f.

275 Balbuena, op. cit., t. 1, lib. 11, estrofa 58. Hay otros ejemplos parecidos: "El duro freno le llamaba en vano" (t. 1, lib. 7, estrofa 100); "detuvo el brioso paso al firme freno" (t. 2, lib. 20, estrofa 113); "si fundamento al paso, freno estrecho" (lib. 22, estrofa 56). Pero tampoco desconoce el manejo verdadero de un caballo: "El moderado freno / al bueno hace mejor, y al malo bueno" (t. 2, lib. 19, estrofa 54). El texto oscila entre la mentira poética (freno duro) y la verdad hipológica (freno blando).

276 Céspedes, Poema de la pintura: "De los sangrientos frenos y bozales: / tal con el tremolar de Libia pluma / volaban por los campos desiguales / con ánimos y pechos varoniles / los [caballos] del carro feroz del grande Aquiles" (p. 392). Aquiles, no un "segundo Ganimedes".

277 Lope de Vega y Carpio, Hamete de Toledo, ed. digital de Gemma Burgos Segarra, a partir de la Novena parte de las comedias de Lope de Vega Carpio: "Le puso en la boca un freno / con que le oprime y desvía. / Y aunque es el caballo bueno, / mal puede libre gozallo / siendo el aderezo ajeno, / que aunque es del turco el caballo, / es del rey de España el freno" (Acto I, vv. 336-342). Disponible en el portal de la Biblioteca Digital Artelope, www.artelope.uv.es. 
vieras / al Rey regir tanto monstruo / al arbitrio de una rienda" ${ }^{278}$. El rey es el lugarteniente de la razón que impera sobre los instintos animales del populacho mediante la autoridad de las riendas.

El retrato de Góngora es el único en violar sistemáticamente todas las convenciones del género ecuestre: el jinete, no robusto; el caballo, galán y vistoso, pero sin fortaleza e inútil para la caza; y los frenos, o el brillo dorado de los frenos, sin mencionar siquiera la voz "freno", suave: "el oro que süave lo enfrenaba” ${ }^{279}$. La razón no es sólo práctica — con dureza no se gobierna un caballo-, sino poético-filosófica: la ley del hierro en el freno no tiene nada que ver con la ternura de una forma imposible que es y no es. La verdadera razón no "mide" (Agustín de Tejada) ni "oprime" (Lope) "lo bruto" (Calderón), sino que cabalga con él, ya que sin el momento de la rudeza la propia belleza degenera en preciosismo. "Si un oscuro no lo cińe - dice Lezama-, piérdese por lo homogéneo de la luz" ${ }^{280}$. Lo único que salva la belleza de la perfección formal es lo bruto, la rudeza de lo no mediado. La “ruda armonía” de la cetrería lo ilustra bien: "Entre el confuso, pues, celoso estruendo / de los caballos, ruda hace armonía / cuanta la generosa ['noble'] cetrería” (Sol. 2, vv. 735737). ¿Dónde sitúa la armonía? Entre las patas de los caballos y en medio de un estruendo tan confuso como celoso ('cuidadoso', 'vigilante') ${ }^{281}$. La confusión no excluye la evidencia; la ciñe para que no se pierda en lo homogéneo de la claridad. "El pintor pasa por una catástrofe, o por un

278 Calderón de la Barca, La banda y la flor, jornada primera, vv. 483-486.

279 No obstante, ver el poema épico de San Ignacio de Loyola de Hernando Domínguez Camargo, texto entreverado de citas gongorinas: "Süave suena aquel, süave responde / esotro llano, mientras Julio pío / en sus martas a Ignacio helado esconde / y lo conduce al techo adonde al frío / el fomento süave corresponde; / el freno allí le entrega a su albedrío, / porque pueda regirlo, soberano, / el maestro dictamen de su mano". Ver sus Obras, eds. Giovanni Meo Zilio y Horacio Jorge Becco, Caracas, Biblioteca Ayacucho, 1986, lib. 4, canto 6, p. 308, estrofa CCLXXV.

280 Lezama Lima, op. cit., p. 208.

281 Ver la definición del Diccionario de Autoridades: 'El que tiene celos, especialmente si lo manifiesta en el cuidado y vigilancia' (s. v. zeloso [sic]); 'se aplica también al demasiadamente cuidadoso y vigilante de lo que de algún modo le pertenece, si permitir la menor cosa en contra' (op. cit., s. v. zeloso). "Entre el confuso, pues, celoso estruendo", significa, pues, 'entre el estruendo confuso, aunque extremadamente cuidadoso'. 
arrebol, y deja sobre el lienzo el rastro de este paso, como el del salto que le lleva del caos a la composición" ${ }^{282}$. La armonía pasa por la rudeza y deja en el texto el rastro de ese paso, como el del salto que lo lleva de la confusión a la evidencia celosa.

\section{Palomino y Galhego, lectores de Góngora}

Blanco ha recordado en un par de ocasiones que la descripción que ofrece Palomino de dos de los retratos ecuestres de Vélazquez se inspira en el retrato ecuestre de las Soledades ${ }^{283}$. Tiene razón, pero no son sólo dos los casos, sino cuatro; y, además, muy distintos entre sí.

Los dos ejemplos que menciona Blanco son La reina doña Isabel de Francia, a caballo (1635-36, Madrid, Museo del Prado) y El retrato ecuestre del conde duque de Olivares (h. 1634, Madrid, Museo del Prado). La

282 Deleuze y Guattari, ¿Qué es la filosofía?, p. 204. Se refiere en concreto a los arreboles del Greco: "El arte transforma la variabilidad caótica en variedad caoidea, por ejemplo, el arrebol gris-negro y verde del Greco” (p. 206). El neologismo caoidea designa una idea cuya perfecta articulación no excluye el caos que la atraviesa. En ese sentido una caoidea es lo opuesto de una idea meramente caótica. Góngora y el Greco transforman la variabilidad meramente caótica en variedad caoidea, es decir, en una síntesis disyuntiva del "número", que es orden, y la "confusión", que es desorden. La "fábrica escrupulosa [...] aunque incierta" (v. 79) de la Soledad segunda es una caoidea neta, el despliegue escrupuloso de la propia incertidumbre; no la incertidumbre incierta, sino la incertidumbre escrupulosa, la incertidumbre determinada. Umberto Eco, Las poéticas de Joyce, trad. Helena Lozano Miralles, Barcelona, Debolsillo, 2011, prefiere el concepto joyceano de chaosmos, que significa lo mismo: "En lo vivo mismo del caos, toma forma una especie de orden que no es ya matriz formal sino el orden mismo de nuestro ser en el mundo" (p. 114). El orden no sucede al caos, sino que brota de su propio interior. La escrupulosidad del objeto está "mediada" (Hegel) por la incertidumbre, sin que podamos separar la una de la otra. Tan incorrecto es llamar a Góngora caótico como lógico. No es ninguna de las dos cosas; es escrupulosamente incierto, neutral: no separa el "si" del "no". La invención de la lengua de Góngora consiste en la variedad caoidea.

283 Mercedes Blanco, "Lienzo de Flandes: Las Soledades y el paisaje pictórico", en Actas del IV Congreso de la Asociación Internacional Siglo de Oro (AISO) (Alcalá de Henares, 22-27 de julio de 1996), eds. María Cruz García de Enterría y Alicia Cordón Mesa, Alcalá, Universidad de Alcalá, 1998, t. 1, pp. 263-274 (pp. 266-267); y “Góngora et la peinture", Locvs Amoenvs, 7 (2004), pp. 197-208 (p. 208). 
descripción de La reina doña Isabel de Francia, a caballo dice (las cursivas se refieren a las palabras tomadas directamente de las Soledades):

Retrató también admirablemente Velázquez a la muy alta y católica señora dońa Isabel de Borbón, reina de Espańa, ricamente vestida, sobre un hermoso caballo blanco, a quien el color pudo dar nombre de cisne [...] Está tan ufano, no tanto por eso, como porque parece tasca reverente el oro, que lo enfrena suave, por venerar el celestial contacto de las riendas, que toca la mano, digna de empuñar el cetro de imperio tan grande 284 .

La descripción de El retrato ecuestre del conde duque de Olivares de Velázquez dice:

Otro retrato pintó don Diego Velázquez de su gran protector y mecenas don Gaspar de Guzmán, tercer conde de Olivares, que está sobre un brioso caballo andaluz, que bebió del Betis no sólo la ligereza con que corren sus aguas, sino la majestad con que caminan, argentando el oro del freno con sus espumas ${ }^{25}$.

A estos ejemplos yo añadiría el Retrato de Felipe IV a caballo (perdido):

Después de esto, habiendo acabado Velázquez el retrato de su majestad a caballo, con tan airosa postura, tan arrogante y brioso que no cedía al de Apeles, que tanto celebraron las plumas de los griegos y de los romanos ${ }^{286}$;

284 Antonio Palomino, "Don Diego Velázquez de Silva”, en Vidas, ed. Nina Ayala Mallory, Madrid, Alianza, 1986, $\$ 4$, p. 168.

285 Ibidem, $\$ 4$, p. 169.

286 Ibidem, $\$ 2$, p. 160. Aunque el cuadro se ha perdido, se registran écfrasis de Jerónimo González de Villanueva (“fuerte bridón”, "diestra amenazante”, "César español”, "tu acero fuerte", "Macedón segundo", "tu imperio augusto", "la fuerte plaza cuyo fuerte muro", etc.), Francisco Pacheco ("anímete la augusta, la alta figura / de el Monarca") y Vélez de Guevara ("pincel, que a lo atrevido y a lo fuerte / les robas", "la ferocidad en ti es temida", "el regio dominio"). Los textos en Francisco Pacheco, El arte de la pintura, ed. Bonaventura Bassegoda i Hugas, Madrid, Cátedra, 1990, lib. I, cap. VIII, pp. 210-213 y pp. 212-213; y en las propias Vidas de Palomino, pp. 160-161. La diferencia con el retrato ecuestre de las Soledades salta a la vista. 
Y la descripción de El apóstol Santiago en la batalla de Clavijo (1609) de Juan de Roelas (Fig. 17), que todavía se conserva en la Capilla de Santiago de la Catedral de Sevilla:

No es menos [célebre] el del sagrado apostol Santiago en la célebre batalla de Clavijo, que está colocado en la capilla de su nombre en aquella santa iglesia [la Catedral de Sevilla], donde se ostenta animoso el sagrado adalid, excitando la cólera de su arrogante enfrenado cisne, a cuyos pies se postran muchas turbas de bárbaros, implicados entre sus arneses y banderas ${ }^{287}$.

Rápidamente se advierte que no todas las descripciones son iguales. El retrato ecuestre del conde duque de Olivares, el retrato perdido de Felipe IV a caballo y El apóstol Santiago en la batalla de Clavijo son retratos ecuestres "viriles", y así lo refleja el vocabulario de Palomino:

Sobre un brioso caballo andaluz.

Argentando el oro del freno [sin suavidad] con sus espumas.

Con tan airosa postura, tan arrogante y brioso.

Se obstenta animoso el sagrado adalid, excitando la cólera de su arrogante enfrenado [sin suavidad] cisne.

En cambio, el retrato femenino de La reina doña Isabel de Francia, a caballo dice: "Sobre un hermoso caballo blanco"; y "parece tasca reverente el oro, que lo enfrena suave, por venerar el celestial contacto de las riendas". Los adjetivos hermoso, reverente, suave y celestial ("cerúleo") se reservan exclusivamante para la reina Isabel, mientras que a los varones les corresponden brioso, freno y enfrenado, pero sin suavidad, animoso, el humor colérico y la arrogancia. En otras palabras, Palomino ha deshecho la androginia del retrato ecuestre de Góngora — “difícil mezcla” (Dolce) — y la ha repartido en dos sexos claramente diferenciados: los hombres a un lado y las mujeres al otro. Los adjetivos "suave" y "celestial" les corresponden exclusivamente a las mujeres.

287 Antonio Palomino, "El doctor Pablo [sic] de las Roelas", en op. cit., pp. $94-96$ (p. 95). 
Parecida es la estrategia de Manoel de Galhegos en su Silva topográfica (1637). El cuadro Felipe IV, a caballo es la encarnación misma del imperio español:

\section{... airado}

en jinete veloz se ostenta armado.

Si así le viera el belga en la campaña

al imperio de España

se rindieran las turbas rebeladas,

en rayos del decoro fulminadas.

¡Oh, rey esclarecido!

¿Vos de grabado acero guarnecido?

¿Vos con bastón, en cuerpo y oprimiendo

de un castaño andaluz la inquieta espalda? ${ }^{288}$

En cambio, a su "divina esposa" - La reina doña Isabel de Francia, a caballo-

negó el pincel espíritu a esta copia,

porque acción fuera impropia

si sutil animara la pintura

de una reina de España la hermosura ${ }^{289}$.

La mujer tiene prohibida la "acción", así que el pincel se la niega. Lo curioso del asunto, sin embargo, es que toda la estrofa es imitación de Góngora, en este caso, del soneto "Inscripción para el sepulcro de Domínico Greco":
El pincel niega al mundo, más süave
que dio espíritu a leño, vida a lino.
(OC, I, núm. 269, vv. 3-4).

288 Manoel de Galhegos, Silva topográfica, en Obras varias al Real Palacio del Buen Retiro, Madrid, María de Quiñones, 1637, ff. 1-12. (ff. 2v-3r). Sobre el tema, ver Jesús Ponce Cárdenas, "Pintura y panegírico. Usos de la écfrasis en Manoel de Galhegos", Versants. Revista Suiza de Literaturas Románicas, 3, 65 (2018), pp. 97-123 (p. 105). 289 Galhegos, op. cit., f. 3r. 
Es como si Galhegos se percatara vagamente del parentesco estilístico entre Velázquez y El Greco —a saber, la estética del borrón que el cretense divulgó en España - y utilizara el epitafio de uno para describir el retrato ecuestre del otro, aunque cambiando el sentido. Mientras que en el soneto de Góngora la Muerte le niega al mundo la suavidad del pincel del Greco, en la silva de Galhegos el pincel de Velázquez le niega a la reina Isabel, y sólo a la reina Isabel, el espíritu y la vida que el Greco le insuflaba a la pintura. Góngora no solo no diría tal cosa, sino que en el soneto "Al Puerto de Guadarrama, pasando por él los condes de Lemus", pinta a la marquesa de Ayamonte como una auténtica Amazona: “Tu cerviz pisa, dura, y la pastora / yugo te pone de cristal” (OC, I, núm. 155, vv. 9-10); motivo que repite en la letrilla "Flechando vi, con rigor", donde la pinta cazando jabalíes: "Ved cuán milagrosa y cuánta / es su fuerza, pues la espera / con voluntad una fiera” (OC, I, núm. 177, vv. 11-12). Y no parece que mienta. Según Pinheiro da Veiga, la marquesa de la Cerda "era fea y de poca representación, aunque muy varonil, que como otra Camila $\mathrm{Hi}$ pólita o una Bradamante, anda a menudo a caballo cazando con otras" ${ }^{290}$.

Queda todavía el retrato de El príncipe Baltasar Carlos, a caballo (16351636, Madrid, Museo del Prado), que al ser niño puede ser hombre y mujer a la vez: "Bello Adonis, de hermosura armado"291.

De los tres retratos que menciona Galhegos, el más parecido al de las Soledades sería el retrato del príncipe Baltasar Carlos: un bello Adonis, al mismo tiempo hermoso y armado.

No sé qué opinaría el conde de Niebla, pero sospecho que hubiese preferido parecerse a la efigie imperial de Felipe IV.

\section{LAS FUENTES LITERARIAS}

Resulta un tanto ocioso compulsar las "fuentes" de las Soledades porque casi cada palabra del texto es el "eco repetido" de otra (Dedicatoria, v. 9). El eco no es una copia debilitada de la voz, sino que la voz misma es una suma de ecos: "el eco (voz ya entera)" (Sol. 1, v. 673).

290 Pinheiro da Veiga, Fastiginia. Vida cotidiana en la corte de Valladolid, ed. y trad.

Narciso Alonso Cortés, Valladolid, Ámbito, 1989, p. 101.

291 Galhegos, op. cit., f. 3v. 
Salcedo Coronel recuerda Il ritratto del serenissimo don Carlo Emanuello, duca di Savoia (Turín, 1608) de Marino ("es imitación del Marino en su retrato del duque de Saboya") ${ }^{292}$, pero, caso de existir, el parecido se limita a un solo verso, que repite en el Panegírico al duque de Lerma: "Cetro superïor, fuerza süave" (OC, I, núm. 313, v. 145). En efecto, el Retrato de Marino dice: "Maestà dolce, acerbità soave", 'majestad dulce, aspereza suave ${ }^{293}$. ¿Qué le interesa del retrato ecuestre de Marino? La complementariedad antagónica (Morin) de la fuerza y la suavidad, la majestad desatada ${ }^{294}$. Salcedo Coronel también copia el mismo verso (por eso mienta a Marino), pero sin mencionar la suavidad: "Imperio dulce, gravedad temida" 295 .

Yo diría que la fuente principal del texto es La colosal estatua ecuestre del emperador Domiciano de Estacio (Silvas, lib. 1, 1, vv. 14-21), que sin dejar de ser un retrato marcial ("lleva a Marte su corcel tracio"), también respira benignidad (mitis), paz (pax) y belleza (decor). No es un retrato ni la mitad de suave y andrógino que el de Góngora, pero la "unión” (mixtura) de guerra y paz que transpira el rostro del emperador sin duda está en el origen de la "abreviatura" de modestia y grandeza (Sol. 2, vv. 811-812) del príncipe de las Soledades:

292 Salcedo Coronel, Soledades comentadas, f. 296v.

293 Giovan Battista Marino, Il ritratto del Serenissimo don Carlo Emanuello, duca di Savoia, ed. Giuseppe Alonzo, Roma, Aracne, 2011, p. 83, estrofa 71. Se imprimió siete veces entre 1608 y 1616. El texto se inspira directamente en Claudiano, lo cual podría explicar el parecido con el poema de Góngora. Ver al respecto Marco Corradini, "Forme dell'intertestualità nel Ritratto del Serenissimo don Carlo Emanuello", en Marino e il Barocco da Napoli a Parigi: atti del convegno di Basilea, 7-9 giugno 2007, ed. Emilio Russo, Alessandria, Edizioni dell'Orso, 2009, pp. 57-100. Góngora conocería también el soneto "All'altezza di Toscana", publicado en las Rime (1602): "Tu, congiunto or soave et or severo" (v. 5). Cito por la edición digital de Massimiliano Oronzo, Pescara, 2010, basada en la quinta impresión de las Rime, Venecia, Giovan Battista Ciotti, 1604, y disponible en www.poesialirica.it/RimeMarino.

294 Edgar Morin, Sur l'esthétique, París, Robert Laffont, 2016, p. 84.

295 García de Salcedo Coronel, Retrato panegírico del conde duque de Olivares, ed. Jesús Ponce Cárdenas, Proyecto ARELPH, panegiricos.com, 2018, estrofa XX, vv. 161164. El autor señala el parecido con el Ritratto de Marino en la p. 39. Ver asimismo Jesús Ponce Cárdenas, "Salcedo Coronel e Marino: tessere sabaude in un panegirico spagnolo", Critica letteraria, 174, 1 (2017), pp. 37-62 (p. 56). 
Aquél [el Caballo de Troya], por otra parte, era dańino y ocultaba en su seno a los fieros aqueos; a éste [la escultura ecuestre del emperador Domiciano que entonces estaba en el Foro romano] lo recomienda la benignidad de su jinete: da gozo contemplar su rostro, que presenta las huellas de la guerra unidas a una plácida expresión de paz. Y nadie crea que exagero: su belleza y su prestancia corren parejas con su dignidad. No es mayor la altivez con que, tras el combate, lleva a Marte su corcel tracio, que se enorgullece de su pesada carga y, lanzado al galope, humea a lo largo del río Estrimón que acelera su curso, a impulso de su aliento poderoso ${ }^{296}$.

Sin duda, conocía también al Lesbino de Tasso (Gerusalemme liberata, canto noveno, estrofas 81-82, vv. 641-656), al que menciona por su nombre en el soneto "Al marqués de Ayamonte determinado a no ir a México" al que ya he tenido oportunidad de referirme: "Pisa Lesbín, segundo Ganimedes” (OC, I, núm. 164, v. 8). En efecto, el parecido con el retrato ecuestre de las Soledades no es desdeñable:

Un paggio del Soldan misto era in quella

Turba di sagittarj e lanciatori,

A cui non anco la stagion novella

Il bel mento spargea de' primi fiori.

Pajon perle e rugiade, in su la bella

Guancia irrigando, i tepidi sudori:

Giunge grazia la polve al crine incolto:

E sdegnoso rigor dolce è in quel volto.

296 Publio Papinio Estacio, Retrato de la estatua ecuestre de Domiciano, en Silvas, trad. y notas Francisco Torrent Rodríguez, Madrid, Gredos, 2002, lib. 1, 1, pp. 7-14 (p. 8). La nueva edición latina de la Loeb Classical Library a cargo de David Roy Shackleton Bailey reza: "Adde quod ille nocens saevosque amplexus Achivos, / hunc mitis commendat eques: iuvat ora tueri / mixta notis belli placidamque gerentia pacem. / Nec veris maiora putes: par forma decorque, / par honor, exhaustis Martem non altius armis / Bistonius portat sonipes magnoque superbit / pondere, nec tardo raptus prope flumina cursu / fumat et ingenti propellit Strymona flatu" (Cambridge, [Massachusetts], Harvard UP, 2015, lib. 1, 1, pp. 8-17 [p. 8, vv. 14-21]). Sobre el tema ver Carole E. Newlands, "Embodying the Statue: Silvae 1.1 and 4.6", en Statius' Silvae and the Poetics of Empire, Cambridge, Cambridge UP, 2004: "In praising the emperor through his monument, Statius here continually blurs the boundaries between text and image" (pp. 46-87 [p. 50]). 
Sotto ha un destrier che, di candore, agguaglia

Pur or nell'Apennin caduta neve:

Turbo o fiamma non è, che roti o saglia

Rapida sì, come è quel pronto e leve.

Vibra ei, presa nel mezzo, una zagaglia:

La spada al fianco tien ritorta e breve:

E con barbara pompa in un lavoro

Di porpora risplende intesta e d'oro ${ }^{297}$.

La traducción literal sería:

Mezclado en aquella turba de arqueros y lanceros estaba un paje del Sultán sobre cuyo mentón la joven estación no había esparcido todavía las primeras flores. Perlas y escarcha sobre su mejilla parecen irrigar los tépidos sudores, gracia ańade el polvo a las crines incultas y desdeñosa crueldad dulce en aquel rostro habita. Debajo tiene un caballo cuya blancura no igualan las caídas nieves del Apenino; no hay torbellino o fuego que gire o salga con tanta rapidez, como es el animal pronto y ligero. Vibra una azagaya que ase por la mitad; en el flanco porta una espada retorcida y pequeña que resplandece con agreste pompa, labrada de púrpura y estampada en oro.

La "gracia” femenina alterna con el "polvo" y el "sudor" guerreros, asignándole al rostro del mancebo una belleza que oscila entre la dulzura y el desdén. ¿Qué ocurre? Que tal y como ha señalado la crítica, la relación del bello Lesbino con el sultán Solimán tiene más de un tinte de pederastia ${ }^{298}$. De entre el ejército de guerreros robustos que atraviesa las páginas de la

297 Torquato Tasso, Gerusalemne liberata, ed. Lanfranco Caretti, Turín, Einaudi, 1971, lib. 9, estrofas 81-82.

298 Además del estudio de Schachter citado en la nota 122, pueden verse John Donnelly, "The Moslem Enemy in Renaissance Epic: Ariosto, Tasso, and Camoens", Yale Italian Studies, 1, 1 (1977): "Tasso hints at pederasty between Solimano and Lesbino" (pp. 162-170 [p. 170, n. 21]); y F. David Wondrich, "The Crusade Within: 'L'Arabo imbelle' in Tasso's Gerusalemme liberata", Mediterranean Studies, 7 (1998): "Because Islam originates from the Arabs of Virgil and Catullus, it must be soft and sensual, and this mollitude must embody unrestrained sexualities, both heterosexual and (we must assume) homosexual" (pp. 101-116 [p. 114]). 
Jerusalén de Tasso ("vedi le membra de' guerrier robuste"299, "tre volte il cavalier la donna stringe / con le robuste braccia" 300 , "lunge / ratto si svia da le robuste braccia"301, "l'arme intorno / a le robuste membra"302, etc.), ¿por qué se fija Góngora en el único que no lo es? ¿Por qué el afeminado Lesbino en lugar del robusto Tancredo?

Por las mismas razones que el retrato de Lesbino - efebo sexualmente ambiguo montado en un caballo blanco lujosamente enjaezado-, yo tampoco descartaría el retrato ecuestre de los Cazadores de Filóstrato el Viejo, texto editado una decena de veces entre los siglos XVI y XVII, citado por numerosos tratadistas de arte e imitado nada menos y nada más que por Tiziano en dos cuadros propiedad de los Austria ( $L a$ ofrenda a Venus y La bacanal de los andrios) ${ }^{303}$ :

Yacen alrededor de aquel muchacho [meirakion] unos hermosos jóvenes [neaniai kaloi] que se ocupan de hermosas tareas [kala epitëdeuontes], siendo como son de origen noble ${ }^{304}$.

Y un poco más abajo:

En cuanto al muchacho [meirakion], monta un caballo blanco [hippou leukou], como ves, con la cabeza torda y la frente rodeada de un círculo blanco [es decir, estrellado], igual que una luna llena; sus

299 Tasso, op. cit., canto 13, estrofa 61.

300 Ibidem, canto 12, estrofa 57.

301 Ibidem, canto 7, estrofa 96.

302 Ibidem, canto 15, estrofa 2.

303 Ver al respecto la tesis doctoral inédita de Frau Paola, "Circolazione e trasmissione del testo", en Le Eikónes di Filostrato Maggiore. La fortuna del testo nella letteratura artistica e nell'arte del Cinquecento e di inizi Seicento, Florencia, Università degli Studi Firenze, 2016, pp. 35-55. La deuda directa de Tiziano con respecto a Filóstrato es un hecho conocido por parte de la historiografía del arte. Sobre el posible influjo de Filóstrato en la obra de Góngora, ver Rubén Soto Rivera, "El cíclope de Filóstrato el Viejo en el Polifemo de Góngora”, Confluencia, 16, 2 (2001), pp. 99-105; Humberto Huergo Cardoso, "El zurrón de Polifemo. Naturaleza y alegoría en el Polifemo de Góngora", Bulletin of Spanish Studies, 83, 2 (2006), pp. 187-212 (pp. 187-190); y Jesús Ponce Cárdenas, "Sobre el paisaje anticuario: Góngora y Filóstrato”, en La Edad del Genio, pp. 375-396. 304 Filóstrato, "Cazadores", en Heroico. Gimnástico. Descripciones de cuadros. Calístrato. Descripciones, ed. y trad. Francesca Mestre, Madrid, Gredos, 1996, pp. 268-271 (p. 269, 3). 
adornos son de oro y las bridas de escarlata persa. [...] Quizá alguien ponderará también sus mejillas, su nariz bien proporcionada y cada uno de los rasgos de su rostro; sin embargo, lo que a mí más me gusta es el espíritu [phronèma] que denota su aspecto ya que se percibe la fuerza de cazador [thēratès errōtai $]^{305}$.

La explicación del propio Filóstrato resulta desconcertante: "No paséis de largo, cazadores, ni espoleéis a los caballos antes de que nosotros averigüémos qué es lo que pretendéis y cuál es vuestra presa. Vosotros decís que perseguís un jabalí y yo puedo ver los destrozos que ha hecho este animal [...] Sin embargo, creo que vosotros, mientras perseguiais la belleza de aquel muchacho, habéis sido capturados por ép' ${ }^{306}$. El narrador puede ver los destrozos causados por el jabalí, pero ellos, el cortejo de hermosos cazadores que se ocupan de tareas hermosas, sólo tienen ojos para la belleza del muchacho, que los ha cazado a ellos. En otras palabras, el texto de Filóstrato trata sobre dos cazas distintas: una montería de jabalíes y una caza de amor inequívocamente homosexual. No sé si el texto en su conjunto sea una "novela de iniciación homosexual dirigida a un menor" y dominada por "la temática de la inversión", como sostiene Mathieu-Castellani, pero el capítulo de los Cazadores ciertamente respalda la tesis ${ }^{307}$.

Dos de los textos citados son ecfrásticos: La colosal estatua ecuestre del emperador Domiciano de Estacio y los Cazadores de Filóstrato el Viejo, los dos, además, trasladados a la estampa por Adriaen Collaert (Fig. 18) y por Jaspar Isaac (Fig. 19), respectivamente ${ }^{308}$. No pocos de los panegíricos que he mencionado en este trabajo, empezando por el Elogio al retrato de

305 Ibidem, p. 269, 4.

306 Ibidem, pp. 268-269, 1.

307 Gisèle Mathieu-Castellani, "Une leçon d'amour en soixante-cinq tableaux ou l'enigme du sexe dans les images", en Le Défi de l'art: Philostrate, Callistrate et l'image sophistique, eds. Michel Costantini, Françoise Graziani y Stéphane Rolet, Poitiers, Presses Universitaires de Rennes, 2006, pp. 153-169 (p. 160). Cita dicho estudio Waissbein, op. cit., p. 199.

308 Nótese, de todos modos, la estrategia de Isaac. Contra lo que dice el Cazadores de Filóstrato ("mientras perseguíais la belleza de aquel muchacho, habéis sido capturados por él"), el grabado no se centra en la caza homosexual, sino en la caza del jabalí (La chasse des bestes noires o La caza de bestias negras). La caza marginal del jabalí ocupa el espacio central del grabado y la caza verdaderamente central, la montería homosexual, desaparece por completo. 
Espinosa, también se inspiran en pinturas, reales o imaginarias ${ }^{309}$. ¿Podemos decir lo mismo acerca de las Soledades? ¿Es el retrato de Góngora la pintura de borrones de una pintura de borrones?

\section{LAS FUENTES ARTISTICAS}

De las decenas de cuadros y estampas de retratos ecuestres regios — retratos de emperadores, reyes y otras figuras de autoridad, sin incluir las estampas de cetreros a caballo (Fig. 1) - que empezaron a circular en España hacia la segunda mitad del siglo XVI, es probable que Góngora conociera: 1) el retrato de Carlos V en la batalla de Mülhberg (1548) de Tiziano, acaso el retrato ecuestre más sonado de todos los tiempos y que entre 1604 y 1626 aproximadamente colgaba en la Casa del Pardo, casa de recreo mencionada frecuentemente en la poesía del autor; 2) algunos, si no todos, de los grabados de la popularísima serie Imperatorum XII (Los doce emperadores romanos a caballo) de Jan van der Straet (Fig. 20); entre ellos, el Retrato ecuestre de la estatua del emperador Augusto (Fig. 2) y el Retrato ecuestre del emperador Domiciano (Fig. 18) ${ }^{310}$; 3) algunos, si no todos, de los grabados

309 Ver, por ejemplo, las palabras de López de Estrada en su introducción a la Obra en prosa de Espinosa: "La primera pieza panegírica que examinamos tiene un título un tanto anómalo: es un elogio, pero no al señor, sino a su retrato. Y, en efecto, en el comienzo de la obra el autor escribe como si estuviera delante de la misma pintura" (p. 83). Jesús Ponce Cárdenas también se ha referido al asunto en su edición ya citada del Retrato panegírico del conde duque de Olivares, pp. 14-25.

310 Existe una amplia bibliografía al respecto. Ver siquiera Kathleen Christian "The Twelve Caesars", en Harvard Encyclopedia of the Classical Tradition, eds. Anthony Grafton, Glenn W. Most y Salvatore Settis, Cambridge, (Massachusetts), Harvard UP, 2010: "Cycles of Twelve Caesars became unabashed expressions of imperial power in the princely residences of Europe" (pp. 155-156 [p. 156]). Existían también bustos de mármol, bien estudiados por Stephan Friedrich Schröder, "Las series de Doce Emperadores", en AA.VV., El coleccionismo de escultura clásica en España. Actas del simposio, 21 y 22 de mayo de 2001, Madrid, Museo del Prado, 2001, pp. 43-60: "El coleccionismo de escultura de la Casa Real empieza con los retratos de aquellos doce emperadores romanos que en el Renacimiento eran conocidos a través de las Vitae Caesarum del escritor romano Suetonio" (p. 44). Y sobre el busto del emperador Augusto en particular aporta un dato sumamente curioso: "Augusto fue representado habitualmente con el rostro idealizado y joven, incluso con sesenta y un años” (p. 44). ¿Lo sabría Góngora? 
de la serie homónima de Antonio Tempesta (Fig. 21); 4) el Retrato ecuestre del duque de Lerma de Rubens (Fig. 22); y 5) el Retrato ecuestre de Rodrigo Calderón (Fig. 23), también de Rubens, ambas personalidades — Lerma y Rodrigo Calderón- protectores de Góngora ${ }^{311}$.

Por lo que se refiere al Retrato ecuestre del duque de Lerma nada más ${ }^{312}$, sin entrar en consideraciones acerca del Retrato ecuestre de Rodrigo Calderón ${ }^{313}$, se guardaba hasta el año

$311 \mathrm{El}$ caso del duque de Lerma está ampliamente documentado. Por lo que respecta a Rodrigo Calderón, ver Robert Jammes, La obra poética: "Don Luis [...] no tardó en convertirse en el protegido de don Rodrigo Calderón” (p. 277). Jammes cita además cartas de Góngora donde declara que "el mío [marqués] de Iglesias ha hecho maravillas en mi pretensión” (p. 277, n. 57) y “[da] gracias a Dios que lo conocí y traté” (p. 278, n. 79).

312 Es un cuadro muy comentado. Ver, entre otros, Simon A. Vosters, "El Retrato ecuestre del duque de Lerma", en Rubens y España. Estudio artístico-literario sobre la estética del Barroco, Madrid, Cátedra, 1990, pp. 40-50; y John F. Moffitt, "Rubens's Duke of Lerma Amongst 'Imperial Horsemen'”, Artibus et Historiae, 15, 29 (1994), pp. 99-110.

313 El inventario de 1651 de los bienes artísticos de Gaspar de Haro y Guzmán en cuya posesión se hallaba el cuadro, lo describe de la siguiente manera: "Una pintura en lienzo grande con un árbol, debajo de él el retrato de don Rodrigo Calderón en un caballo rucio, armado de medio cuerpo arriba con un cuello y una banda encarnada con puntas al brazo izquierdo, y con la mano derecha levanta las riendas. De la mano de Rubenes" (Getty Provenance Index, Archival Inventory E-81, p. 50, asiento 0207). El estudio más completo del cuadro es el de Justus Müller Hofstede, "Rubens' Reiterporträt des don Rodrigo Calderón, Favorit des Herzogs von Lerma", Wallraf-Richartz-Jahrbuch, 63 (2002), pp. 259-282. El inventario de sus bienes artísticos ha sido reproducido por Juan José Martín González, "Bienes artísticos de don Rodrigo Calderón", Boletín del Seminario de Estudios de Arte y Arqueología, 54 (1988), pp. 267-292. Poseía, entre otros, veintidós cuadros sobre la expulsión de los moriscos, de la cual era un ferviente defensor, y "de un gran pintor llamado Rubenes" (p. 288, n. 47) un Apostolado completo y La adoración de los Magos que hoy cuelga en el Prado. El palacio que poseía en Madrid se construyó en 1609 y "estaba ubicado en la calle del Reloj o de dońa María de Aragón, hoy de San Bernardo”. Dada la estrecha amistad que lo unía a Rodrigo Calderón, es razonable suponer que a partir de 1617 — después de las Soledades, entonces— Góngora conociera de primera mano la colección. Datos de interés en Alejandro Vergara, "Don Rodrigo Calderón y la introducción del arte de Rubens en España”, Archivo Español de Arte, 267 (1994), pp. 275-283. Sobre el tema de la expulsión de los moriscos en particular, presente de forma oblicua en las Soledades, ver Yolanda Gil Saura, "La tapicería 
1606, fecha en que pasó a las colecciones reales, en la famosa Quinta de la Ribera del valido del rey, mencionada ya en la Descripción de las cosas curiosas y necesarias de saberse a los que partieren de Irún para Madrid, que se refiere a ella como "la Huerta del duque de Lerma"314. Era una parada obligatoria en el camino Irún-Madrid. Y lo primero que veía el viajero al entrar en el palacio eran doce óleos gigantescos, basados en los Imperatorum XII de Van der Straet: "Primeramente, en el zaguán, los Doce emperadores a caballo en doce lienzos a dos varas de alto poco más o menos, pinturas flamencas de buena mano"315; e inmediatamente después, en la Galería principal, "el Retrato del señor duque de Lerma a caballo, guarnecido con marco de pino dorado de oro y negro, de Pedro Rubenes, original" ${ }^{16}$; rodeado de "ciento y una cabezas de emperadores, guarnecidas de la misma manera, de dos tercias de alto, de mano de Vicente Carducho"317.

Como si este alarde de poderío fuera poco, la Quinta del Prior, en pleno corazón de Madrid, donde sabemos que Góngora estuvo ${ }^{318}$, albergaba una segunda serie de los Imperatorum XII, descrita en el inventario

de la expulsión de los moriscos. Un proyecto frustrado de Rodrigo Calderón”, Locvs Amoenvs, 16 (2008), pp. 133-153.

314 Anónimo, Descripción del camino de Irún para Madrid y Portugal. Descripción de las cosas curiosas y necesarias de saberse a los que partieren de Irún para Madrid, en L'Espagne au XVIe et au XVIIe siècle. Documents historiques et littéraires, ed. Alfred Morel-Fatio, Heilbronn, Henninger Frères, 1878, pp. 241-249 (p. 243). Menciona el dato Luis Cervera Vera, El conjunto palacial de la villa de Lerma, Lerma, Asociación Amigos del Palacio Ducal, 1996, t. 1, p. 94, n. 230.

315 José María Florit y Arizcún, "Inventario de los cuadros y otros objetos de arte de la quinta real llamada La Ribera, en Valladolid”, Boletín de la Sociedad Española de Excursiones, 14 (1906), pp. 153-154 (p. 154). Sobre el tema puede verse Margarita Ana Vázquez Manassero, "Twelve Caesars' Representations from Titian to the End of the 17th Century of the Spanish Monarchy", en Actual Problems of Theory and History of Art: Vol. 5 2015, eds. Svetlana V. Maltseva, Ekaterina Staniukovich-Denisova y Anna V. Zakharova, San Petersburgo, NP-Print, 2015, pp. 655-663.

316 Florit y Arizcún, op. cit., p. 154.

317 Ibidem, p. 154.

318 Así se desprende de la anécdota de Vaca de Alfaro que reproduce Rafael Ramírez de Arellano, Ensayo de un catálogo biográfico de escritores de la provincia y diócesis de Córdoba, Madrid, Tipografía de la Revista de Archivos, Bibliotecas y Museos, 1922: "Estando en Madrid en casa del duque de Lerma, sucedió que de la calle tiraron una pedrada al balcón y quebraron una vidriera. Dijo don Luis de Góngora: 'Algún muchacho cordobés la tiró’” (t. 1, p. 236). 
de 1607 como "doce emperadores a caballo de doce cuadros de dos varas y media de alto y dos de ancho, poco más o menos, con sus letreros de los nombres" (Fig. 24) ${ }^{319}$.

Cuesta creer que el autor del Panegírico al duque de Lerma (1617) no conociera ninguna de estas obras, infaltables, además, en numerosas colecciones de la época, como las de Gil Ramírez de Arellano ("doce cuadros de doce emperadores romanos, retratos enteros a caballo") ${ }^{320}$, Rodrigo de Herrera ("doce emperadores a caballo") ${ }^{321}$ y Philippe Charles d'Arenberg ("doce retratos a caballo de la Casa de Austria con sus batallas y historias debajo de ellos") ${ }^{322}$. El conde de Niebla también poseía su serie, obra de un tal Mateo Martínez según el modelo de Van der Straet o de Tempesta ${ }^{323}$. Pero si las conocía, no dejaron huella en las Soledades (sí

319 Inventarios en Sarah Walker Schroth, The Private Picture Collection of the Duke of Lerma, tesis doctoral inédita, Nueva York, New York University, 1990, p. 261, asientos 293-304. Conocería, entonces, muchas de las trescientas "pinturas de diversas suertes a lo divino" (p. 238) y "retratos y pinturas a lo humano" (p. 251) que llegó a acumular el duque en el palacio de Madrid; entre otras, la Salomé con la cabeza del Bautista de Ticiano que hoy cuelga en el Museo del Prado, descrita en el inventario como "un cuadro de Herodía con la cabeza de s[an] Ju[an Bautista], original del Ticiano" (p. 246, asiento 80). De la misma historiadora, ver también su documentado "The Duke of Lerma's Palace in Madrid: A Reconstruction of the Original Setting for Cristoforo Stati's Samson and the Lion", Apollo, 154, 274 (2001), pp. 1-21, con nuevos documentos que permiten reconstruir en detalle las piezas del camarín y el diseño del jardín y la huerta. El óleo de la Estatua ecuestre del emperador Tito que reproduzco no pertenecía a la colección madrileña del duque de Lerma, pero ofrece una idea aproximada del tipo de retratos a los que alude el inventario: óleos de muy diversa calidad, basados bien en los Imperatorum XII de Van der Straet, bien en la serie homónima de Tempesta.

320 "Doce cuadros de doce emperadores romanos, retratos enteros a caballo" (asiento 14). El inventario está disponible en las Provenance Index Databases del Getty Research Institute, E-825, www.getty.edu.

321 "Doce emperadores a caballo, tasados en dos ducados cada uno" (asiento 10); y "los doce emperadores grandes, a ducientos reales cada uno" (asiento 12). Inventario en las Provenance Index Databases del Getty Research Institute, E-838.

322 "Doce retratos a caballo de la Casa de Austria con sus batallas y historias debajo de ellos" (asiento 68); y "veintitrés retratos grandes a caballo de tres varas de alto y dos varas de ancho" (asiento 172), entre muchos otros. Inventario en las Provenance Index Databases del Getty Research Institute, E-994.

323 Ver al respecto Cruz Isidoro, op. cit., 156: "El 26 de marzo de 1602 se libraron 720 
en el Panegírico, que al ser un poema de propaganda se permite caer en el tópico del vir militaris) por las razones que vengo exponiendo ${ }^{324}$ : son todos retratos imperiales, e imperalistas, que no tienen nada que ver ni con la delicada complexión del príncipe de las Soledades, más parecido al meirakion de Filóstrato que al Retrato de la estatua ecuestre de Tito de Collaert, ni con el "estilo suave" de su autor, el uno reflejo del otro.

Que yo sepa, el único retrato ecuestre al alcance de Góngora que satisface ambos requisitos es el de San Martín y el pobre (Fig. 25) de su admirado "Domínico Greco" (OC, I, núm. 269), que entonces se custodiaba en la lujosa capilla de San José de Toledo ${ }^{325}$, ciudad en la que Góngora estuvo más de una vez y que sirve de trasfondo para al menos cinco de sus composiciones: el nocturno "Al favor que San Ildefonso recibió de Nuestra Señora” (1616), recuerdo del San Ildefonso de El Greco (1601-1603) ${ }^{326}$; el romance que empieza "Castillo de San Cervantes, / tú que estás par de Toledo" (1591), castillo, por cierto, “robusto, si no galán” (OC, I, núm.

reales al pintor Mateo Martínez de orden del conde de Niebla don Manuel [Manuel Alonso Pérez de Guzmán] por doce cuadros de emperadores con sus marcos".

324 Ver sobre el tema María Dolores Martos Pérez, "Representaciones barrocas del poder: Góngora, Rubens, Pantoja de la Cruz", en El duque de Lerma: Poder y literatura en el Siglo de Oro, eds. Juan Matas Caballero, José María Micó y Jesús Ponce Cárdenas, Madrid, Centro de Estudios Europa Hispánica, 2011, pp. 207-233 (pp. 218-229). El asiento del inventario de Gaspar de Haro alusivo al cuadro de Rubens (p. 228) está salpicado de errores de transcripción.

325 La historia de la Capilla de San José es bien conocida. Entre la docena de estudios dedicados al tema, destacan dos de Fernando Marías, "Capilla de San José, Toledo", en El Griego de Toledo, pintor de lo visible y lo invisible, pp. 277-281; y "El Greco among the Conversos: The Case of the Chapel of Saint Joseph", en Creative and Imaginative Powers in the Pictorial Art of El Greco, ed. Livia Stoenescu, Turnhout, Bélgica, Brepols, 2016, pp. 13-37. También es útil Palma Martínez-Burgos García, El Greco en la Capilla de San José, 1597-1599, Toledo, Antonio Pareja, 2014. Aprovecho la oportunidad para agradecerle a la profesora Martínez-Burgos el envío del pdf.

326 En su documentado "La dignidad de la pintura y la lucha contra la alcabala: Lope de Vega y el Greco", Antonio Sánchez Jiménez se pregunta si el poema no tendrá que ver con el Plano y vista de Toledo, imitado igualmente por Lope, lo cual también me parece una hipótesis digna de consideración. Ver Antonio Sánchez Jiménez, El pincel y el Fénix: pintura y literatura en la obra de Lope de Vega Carpio, Madrid, Universidad de Navarra, 2011: "Cabría preguntarse si Góngora imitó conscientemente el soneto de Lope ['Cuelgan racimos de ángeles que enrizan'], si para ello acudió a la misma fuente [el cuadro Plano y vista de Toledo del Greco]" (pp. 135-173 [p. 172]). 
89, v. 5): o sea, el reflejo invertido del príncipe de las Soledades; el soneto "De la capilla de Nuestra Señora del Sagrario, de la Santa Iglesia de Toledo" (1616) (adornada con tres lienzos caravaggistas de Carlo Saraceni, "piezas de capital importancia en la introducción del tenebrismo en España”) 327 , la canción “En el sepulcro de Garcilaso de la Vega” (1616) y la comedia Las firmezas de Isabela (1610), donde inserta una vista detallada de la ciudad que algunos han comparado con el famoso cuadro del candiota (yo no veo el parecido) ${ }^{328}$.

Conviene también recordar que varias de las composiciones del poeta están dedicadas a personalidades toledanas. Entre otras, los sonetos "A don Luis de Vargas" (1588), "que tiene sus casas sobre los muros de Toledo, que miran a la vega" ${ }^{229}$; y "Al doctor [Eugenio de] Narbona, pidiéndole unos albarcoques que había ofrecido enviarle desde Toledo" (1620), hermano del abogado del Greco en el pleito de Illescas y amigo personal del pintor ${ }^{330}$.

Más significativo aún es el testimonio de Faria e Sousa en el que llama al Greco "el Góngora de los poetas para los ojos" 331 . Se parecían y sus con-

327 Alfonso E. Pérez Sánchez (ed.), Caravaggio y el naturalismo español, Madrid, Raycar, S. A., 1973, Catálogo, s. p.

328 Sobre el lugar de Toledo en la obra del poeta, ver, entre otros, Laura Dolfi, "Sobre Góngora, Toledo y El Greco" (2009), en Luis de Góngora. Cómo escribir teatro, Sevilla, Renacimiento, 2011, pp. 259-278; y Mercedes Blanco, “Toledo como jeroglífico en las Firmezas de Isabela”, en Góngora o la invención, pp. 255-292.

329 Salcedo Coronel, Obras comentadas, II, primera parte, p. 218.

330 Ver al respecto Richard L. Kagan, "La Toledo del Greco", en El Greco de Toledo, eds. José Manuel Pita Andrade y Alfonso E. Pérez Sánchez, trad. Carlota Millán, Ángel Schmidt y Julia Silva, Madrid, Ministerio de Cultura, 1982, pp. 35-73 (p. 69). Otras composiciones dedicadas a personalidades toledanas son: "Inscripción para el sepulcro de doña María de Lyra, natural de Toledo" (1594), "A doña Luisa de Cardona, monja de Santa Fe de Toledo" (ant. a 1594), "Al licenciado Alonso Lobo, racionero de Toledo" (1594-1604) y "De don Antonio Coloma, canónigo de Toledo y arcediano de Madrid" (1625).

331 Manuel de Faria e Sousa, Fuente de Aganipe o Rimas varias. Parte primera, Madrid, Carlos Sánchez Bravo, 1646: "El llamar [Góngora] 'mariposa' al arroyo no es cosa que la pueda sufrir ningún juicio maduro, y de esto están llenos aquellos versos, y de otros lances aún más exorbitantes, procedidos de falta de ciencia y de juicio, y de una lujuriosa sobra de ingenio y de osadía. El mismo ejemplo nos hace el gran pintor Domenico Greco, que fue el Estacio y el Góngora de los poetas para los ojos. Pero 
temporáneos notaban que se parecían. ¿En qué exactamente? Los ataques que Quevedo le dirige a Góngora dan en el clavo: "Escribiendo sonetos confusiones; / y en la Mancha, pastores y gañanes" ${ }^{332}$. Se parecían en la estética de la mancha; "sin cuidado en hacer cosas pequeñas, sino con golpes de pincel, en confusión como manchas [in confuse, come macchie], pero fundadas en el buen arte de la pintura, expresando con franqueza [franchezza] cada cosa, tal y como se ve en los paisajes de Tiziano" ${ }^{333}$. Según Quevedo, Velázquez pintaría buenas manchas, suaves tintas carnales (“dar a lo mórbido sentido / con las manchas distantes") 334 , y Góngora malas, sonetos confusiones; los "rasgos" de aquél serían "argucia rara y generosa I de rasgos", como los arabescos de Pedro Díaz Morante ${ }^{335}$, mientras que

vale más una llaneza del Tiziano que todas sus extravagancias juntas, por más que ingeniosas" ("Prólogo", párrafos 36-37).

332 Francisco de Quevedo, "Receta para hacer Soledades en un día”, en op. cit., p. 1161, vv. 18-19.

333 Vicenzo Giustiniani, Carta al señor Teodoro Amideni, en Barroco en Europa, eds. José Fernández Arenas y Bonaventura Bassegoda i Hugas, Barcelona, Gustavo Gili, 1983, pp. 54-60 (p. 56). He corregido ligeramente la traducción con el fin de ajustarla mejor al original: "Settimo, saper ritrarre una cosa grande, come una facciata, un'anticaglia, o paese vicino, o lontano; il che si fa in due maniere, una senza diligenza di far cose minute, ma con botte, o in confuso, come macchie, però con buon artificio di pittura fondata, o con franchezza esprimendo ogni cosa; nel qual modo si vedono paesi di Tiziano, di Raffaele, dei Caracci, di Guido, ed altri simili. L'altro modo è di far paesi con maggior diligenza, osservando ogni minuzia di qualsivoglia cosa come hanno dipinto il Civetta [Herri Met de Bles], Brugolo [¿̨Bruegel el Viejo?], Brillo [Paul Brill], ed altri, per lo più fiamminghi, pazienti in far le cose dal natural con molta distinzione ("Sulla pittura", en Discorsi sulle arti: Architettura, pittura, scultura, ed. Lauro Magnani, Novi Ligure, Alessandria, Città del silenzio, 2006, pp. 45-50 [p. 46]). La fecha de composición se sitúa alrededor de los años 1617-1618, aunque otros historiadores lo consideran más tardío.

334 Cito por la edición de Rodrigo Cacho Casal, "Quevedo y la filología de autor: edición de la silva El pincel”, Criticón, 114 (2012), pp. 179-212 (p. 201, vv. 88-89). La suavidad o morbidezza de la carne se compone de manchas.

335 Quevedo, "Al retrato del rey nuestro Señor, hecho de rasgos y lazos, con pluma, por Pedro Morante", en op. cit., p. 266, vv. 1-2. La voz "rasgo" significa bien garabato, bien bosquejo, cuando no directamente pintura de borrones. Ver, por ejemplo, Hernando Domínguez Camargo: "Se dicen rasgos los caracteres inciertos o delirios airosos que formamos con la pluma en un papel (op. cit., p. 426); Francisco de Holanda, De la pintura antigua y Diálogo de la pintura, ed. Francisco Javier Sánchez 
los de Góngora serían “ojos de culo / todas tus obras y rasgos”336; "los rasgos y lazos / que en otros son borrones y embarazos”337. ¿En qué consiste exactamente la diferencia entre las manchas distantes de Velázquez y los sonetos-mancha de Góngora? ¿Y por qué son una muestra de argucia los rasgos de Díaz Morante mientras que los de Góngora son “ojos de culo"? Cualquiera que sea la respuesta, el debate acerca de la estética de la mancha es ineludible. La claridad no interesa; la evidencia no radica en lo evidente. El quid está en definir en qué consiste la diferencia entre la simple confusión y la "dulce confusión" (Sol. 1, v. 485); qué es un diagrama (Deleuze) y qué es un garabato ${ }^{338}$; qué es la Bedeutung y qué es la Bedeutungsrichtung (Maldiney) ${ }^{339}$.

Cantón, trad. del 1563 de Manuel Denis, Madrid, Visor, 2003: "Vale más un solo rasgo o borrón dado por la maestría de un valiente debujador" (cap. 16, p. 63); y Antonio de Vieira, Sermones varios, Madrid, Antonio González, 1678: "El pintor no se asegura del rasgo que dio de cerca cuando pinta el lienzo, hasta que llega a examinar de lejos y de lo distante mide y tantea mejor la valentía de los colores" (p. 96). Espinosa emplea la voz en el Elogio al retrato del conde de Niebla: "En errantes juegos, / en sus diáfanos pliegos / rasgos con su pluma escribe" (p. 245, vv. 12-14). Es legítimo afirmar que la estética del Seiscientos eleva el garabato a la altura del Arte. Es decir, la pintura "valiente", la pintura de borrones, no se separa del todo del rasgo, del garabato. Tal y como le reprocha Quevedo a Góngora, es "obra y rasgo", obra y desobra, obra y garabato.

336 Quevedo, "Respuesta de don Francisco de Quevedo a don Luis de Góngora”, en $o p$. cit., pp. 1166-1171 (p. 1167, vv. 19-20).

337 Quevedo, Al pincel, vv. 26-27.

338 Por "diagrama" Deleuze entiende la mancha caótica de la cual emerge la figura sin dejar de parecer un borrón, como si oscilara entre el caos y la forma: "El diagrama es de hecho un caos, una catástrofe, pero también el germen de orden o de ritmo" (Francis Bacon, p. 104). Como la pintura de borrones, la lengua de Góngora sería "diagramática": no renuncia a la confusión, pero tampoco se reduce a ella; es un caos, pero también el germen de un orden superior.

339 La Bedeutungsrichtung o 'dirección de sentido' es un concepto fenomenológico que significa "el bosquejo [esquisse] de un modo de apertura al mundo". Su opuesto sería la Bedeutung o el sentido a secas, el horizonte limitado de una forma circunscrita. En términos generales, la poesía de Góngora no significa nada (Bedeutung), sino que da pasos errantes en dirección al sentido (Bedeutungsrichtung); no define un significado, sino que bosqueja un modo de apertura al mundo. Ver al respecto el extraordinario libro de Henri Maldiney, Regard, Parole, Espace, ed. Christian Chaput y Philippe Grossos, París, Éditions du Cerf, 2012, p. 102. 
Liedke no menciona el cuadro en su documentado The Royal Horse and Rider por no tratarse de un retrato ecuestre regio ${ }^{340}$, sino de un estratelata, un 'santo militar' como El apóstol Santiago en la batalla de Clavijo de Roelas (Fig. 17); aunque como advierte socarronamente don Quijote en la Segunda parte de la novela de Cervantes, San Martín no se distinguió por su valentía, como San Jorge y Santiago Matamoros, sino por su liberalidad. Es el santo del "dar" (vocablo gongorino) ${ }^{341}$; el gesto que lo caracteriza no es el atropello del enemigo, "a caballo, la espada ensangretada, atropellando moros y pisando cabezas", sino, por el contrario, la caridad $^{342}$. Dice Cervantes:

Descubrióla [la imagen] el hombre, y pareció ser la de San Martín puesto a caballo, que partía la capa con el pobre; y apenas la hubo visto don Quijote, cuando dijo:

-Este caballero también fue de los aventureros cristianos, $y$ creo que fue más liberal que valiente, como lo puedes echar de ver, Sancho, en que está partiendo la capa con el pobre y le da la mitad; y sin duda debía de ser entonces invierno; que si no, él se la diera toda, según era de caritativo ${ }^{343}$.

Tuvo que ser un tema popular dentro de la producción del Greco, porque se conservan cinco copias de menor tamaño y diversa calidad: una, muy temprana, en The Art Institute of Chicago (1597-1600); otra en la National Gallery de Washington (1600-1614); otra en el Museo Chimei de Taiwan (1610-1614); otra en una colección particular florentina; y la quinta, bastante torpe y en la que el Greco no habrá intervenido

340 Walter Liedtke, The Royal Horse and Rider: Painting, Sculpture, and Horsemanship, 1500-1800, Nueva York, Abaris Books, 1989. Ver también Walter Liedtke y John F. Moffitt, "Velázquez, Olivares, and the Baroque Equestrian Portrait", The Burlington Magazine, 123, 942 (1981), pp. 529-537.

341 Jáuregui, op. cit., p. 34: "El verbo dar usado con extrañeza". Así en el propio retrato ecuestre de las Soledades: "Daba, / estrellas, su cerúlea piel al día” (vv. 818-819); 'ofrecía las manchas de su piel al día'.

342 Cervantes, op. cit., t. 2, II, cap. LVIII, p. 954. Sobre la pintura de santos a caballo, ver Escardiel González Estévez, "El retrato ecuestre a lo divino: santos y ángeles a caballo", en Nobleza y retrato ecuestre en el arte, ed. Ramón María Serrara, Sevilla, Real Maestranza de Caballería de Sevilla, 2015, pp. 177-232.

343 Cervantes, op. cit., t. 2, II, cap. LVIII, p. 954. 
en absoluto, en el The John and Marble Rigling Museum of Art de Sarasota (h. 1620). El lienzo se considera incluso una de las fuentes de inspiración del Retrato ecuestre del duque de Lerma (1603) de Rubens (Fig. 22), que es, en efecto, una especie de San Martín atiborrado de testosterona, San Martín robusto ${ }^{344}$. No sé si el Greco conocería los Cazadores de Filóstrato —estaba empapado de teoría artística y el griego era su lengua materna-, pero si no es así, el parecido entre ambas obras es muy estrecho ${ }^{345}$.

No se conoce ninguna descripción de la época. La actual del mayor conocedor del Greco de Espańa —Fernando Marías— reza:

Aquél [San Martín de Tours], caballero con armadura en lugar de soldado romano, se aleja por su apariencia contemporánea de la propiedad histórica y parece una puesta en escena de sus ideas [del Greco] acerca de la proporcionalidad natural, incluso a caballo, del hombre y la belleza de los cuerpos estilizados, en un clima elegante y poético, más que ascético o místico, al que ayuda el paisaje toledano de fondo. Esa misma elegancia y graciosa belleza reaparece en las santas vírgenes [María con el Niño entre Santa Martina y Santa Inés, entonces en la misma Capilla] y en los ángeles, pues en los pequeños querubines su naturaleza espiritual termina difuminando su forma y convirtiéndola en materia de nubes ${ }^{346}$.

344 Félix Boix, Retrato ecuestre del duque de Lerma pintado por Rubens, Madrid, Gráficas Reunidas, 1924, pp. 13-14: "Si el dibujo del retrato de Lerma inspiró los ecuestres que hemos citado, a su vez, el primero, como acertadamente ha hecho notar don Ángel Vegue, parece sugerido a Rubens en lo que a la posición del caballo se refiere, por la que tiene el del San Martín pintado por el Greco, que se conservaba en Toledo".

345 Ver al respecto la tesis doctoral inédita de Ionna Goniotaki, Locating El Greco in Late Sixteenth-Century Rome: Art and Learning, Rivalry, and Patronage, Birkbeck College, University of London, 2017, p. 208: "Domenicos began to approach the writings of ancient authors as diverse as Xenophon, Aristotle, Philostratus, Cicero, Quintilian and Pliny in connection with the artistic attainments of antiquity”. Las referencias a Filóstrato son constantes, sin bien ninguna de ellas resulta irrefutable: p. 45 , n. 108 , p. 90 , n. 98 , pp. $92,110,119$ y passim.

346 Fernando Marías, El Greco. Biografía de un pintor extravagante, Madrid, Nerea, 1997, pp. 223-224. La temprana descripción de Maurice Barrès, El Greco o el secreto de Toledo, trad. Alberto Insúa, Madrid, Renacimiento, 1914, también tiene 
Inmediatamente llaman la atención las frases "caballero con armadura en lugar de soldado romano", es decir, en lugar de la robustez del centurión romano de Fréminet (Fig. 26), "la belleza de los cuerpos estilizados", "un clima elegante y poético", y "elegancia y graciosa belleza" (en el sentido de grazia, la belleza no sujeta a medida). Más todavía sorprenden la referencia a las formas difuminadas y la comparación con las nubes. Y, en efecto, si se compara el cuadro del Greco con el San Martín y San Cristóbal (1528-1529) de Pordenone, que sin duda habrá visto en la iglesia de San Rocco, en Venecia, las diferencias saltan a la vista (Fig. 27). Sin entrar en detalles que no vienen al caso, la escena de Pordenone transcurre en un interior claustrofóbico, mientras que la del Greco se desarrolla al aire libre y contra un cielo manchado de nubes ${ }^{347}$.

Recuérdese asimismo cómo empezaba el epitafio de Paravicino "Del Griego aquí lo que encerrarse pudo" (1614):

Blando le oprime, blando mientras huella

el zafir [zafiro] que se hurtó del nudo ${ }^{348}$.

Está también el verso que le dedica Góngora en su propio epitafio (1614), eco del soneto de Paravicino ${ }^{349}$, y que ya he estudiado en otra parte:

interés: “¿Qué noble ternura [tendresse] se exhala de su decorado de la capilla de San José: aquel San Martín casi incoloro, joven seductor [jeune homme charmant, 'joven encantador'] que hace merced de su capa a un compañero menos afortunado; aquel San José, gobernador de un joven príncipe [jeune prince], santificados ambos en la adolescencia, y que los ángeles coronan con las más envolventes y más corteses maneras [les gestes les plus enlaçants et les plus courtois]! (p. 183). No es el horizonte metafísico de ternura de Barbaro, pero tampoco son incompatibles. En su vieja monografía, John F. Matthews, El Greco (1541-1614), Nueva York, Harry N. Abrams, 1953, ha subrayado también el carácter "delicado, casi femenino [dainty, almost feminine] de los pies del mendigo" (Lámina 14, s. p.).

347 "Por fondo, el cielo. No hay más tierra que la que se pisa”, dice bien Manuel Bartolomé Cossío, El Greco, 2 tomos, Madrid, V. Suárez, 1908, t. 1, p. 304. Cossío insiste también en la suavidad del pincel del Greco: "La mancha suave" (t. 1, p. 305); "siempre con suave delicadeza" (t. 1, p. 253); "una pincelada más suave y ligera” (t. 1, p. 97), etc. 348 Paravicino, "Al túmulo de este mismo pintor, que era el Griego de Toledo", en $o p$. cit., p. 176, vv. 1-2.

349 Mercedes Blanco ha subrayado algunas de las correspondencias en su Góngora o la invención de una lengua, pp. 125-128. 
De pórfido luciente dura llave, el pincel niega al mundo, más süave $e^{350}$.

¿En qué sentido sería "süave" el pincel del Greco cuando el príncipe de Esquilache se quejaba, bien al contrario, de su dureza? ${ }^{351}$ La respuesta es: suave como el toque veneciano de Giorgione, "aquel impasto del pincel tan suave que tiempo atrás no existía [quell'impasto di pennello cosi morbido, che nel tempo addietro non $f u{ }^{352}$; "despreciando la diligencia y la perfección con un caos (por así decir) de colores indistintos y mezclados de confusión [sprezzando la diligenza e la finitezza con un caos (per così dire) de colori indistinti e misculi di confusione]"353. En este sentido, tiene razón el Padre Jerónimo de San José al comparar la obra de Paravicino y de Góngora con la pintura de borrones de Tiziano: "Lo mismo [que Tiziano] parece pretendieron en este tiempo nuestro Hortensio [Paravicino] y Góngora, éste en el verso y aquél en el verso y prosa [en los sermones]; aunque en la extravagancia de ésta [de la prosa] fue más especialmente insigne el Hortensio, como el Góngora en la poesía, subiendo ambos el estilo hasta la celsitud del precipicio en el hablar y el escribir" ${ }^{354}$. La celsitud de un preci-

350 Humberto Huergo Cardoso, "Góngora y la estética del borrón. Otra vez el soneto al Greco”, Creneida, 5 (2017), pp. 280-332.

351 Borja, príncipe de Esquilache, Carta al conde de Lemos, don Francisco de Castro, en op. cit:: "Que escriba a lo moderno le aconsejo / al que aplausos inútiles pretende, / y al Greco imite el hórrido bosquejo, / que el uso ahora estas durezas vende" (pp. 213-225 [p. 214, vv. 22-25]). Escribir "a lo moderno" equivalía, pues, a imitar la horrenda pintura de borrones de El Greco. La alusión a Góngora es transparente.

352 Boschini, La carta del navegar pitoresco con la Breve instruzione, p. 709. Comparar con Manuel de Faria e Sousa en el citado Retrato de Albania: "Vuelvo a tomar el pincel blando" (Fuente de Aganipe o Rimas varias. Parte segunda, f. 114r); y con el Calderón de El principe constante, ed. Enrica Cancelliere, Madrid, Biblioteca Nueva, 2000: "En los matices / sutiles pinceles logran / unos visos, unos lejos, / que en perspectiva dudosa / parecen montes tal vez / y tal ciudades famosas" (op. cit., primera jornada, vv. 235-240). Los cuatro sintagmas — pincel suave, pennello morbido, pincel blando y pincel sutil - aluden a las dudosas perspectivas de la pintura de borrones.

353 Boschini, La carta del navegar pitoresco con la Breve instruzione, p. 725.

354 Padre Jerónimo de San José (Jerónimo Ezquerra de Rozas), El genio de la Historia, Zaragoza, Diego Dormer, 1651, segunda parte, cap. 4, p. 126. Todo el libro está 
picio $^{355}$. Góngora y Paravicino pretendían lo mismo que Tiziano — pintar borrones - , y para conseguirlo arrastran la escritura a la altura negativa de un precipicio que se despeña hacia arriba en lugar de hacia abajo; "dulce abismo"356, "dulce horror"357, "dulce confusión" 358 que no sabe si "muere o triunfa" 359 y que "cuanto más cae, se erige"360. Paravicino se enorgullece de ello: "Gózome en verme caído" 361 . La palabra goza de verse caída, ya que sólo en el abismo roza la ternura de un decir imposible.

Si sumamos el cuadro del Greco y los dos sonetos, tenemos: mancebo de belleza estilizada, en lugar de un fornido soldado romano, sobre un caballo cerúleo igualmente estilizado (Fig. 28); cielo de nubes informes, cerúleas también (Fig. 29); una mancha de oro reminiscente de un "freno" (Fig. 30); lejos extremadamente borroso ("quiere lejos, como pintura del Greco", dice Espinosa) (Fig. 31) ${ }^{362}$; blandura extrema ("blando le oprime, blando"); zafiro ('piedra preciosa de color cerúleo’) ${ }^{363}$ o, todavía mejor, "en zafir manchado a luces", mancha de color cerúleo ${ }^{364}$; "pincel

salpicado de referencias a la pintura.

355 Comparar con Trillo y Figueroa, op. cit:: "Los adornos, precipicios y digresiones capaces de toda erudición" (Neapolisea, p. 426); "valentía de voces, arrojamientos, pinturas y precipicios" (Neapolisea, p. 433); "surcando precipicios, del exceso / bien que mentido, examinaba el peso" (Neapolisea, lib. 6, estrofa 20); "sin precipicio hiciera / mal obediente a su veloz carrera" (Neapolisea, lib. 8, estrofa 8). El nuevo concepto de "exceso" reemplaza la vieja noción de "proporción". La poesía se entrega a cierto "exceso", aun a riesgo de despeñarse por un "precipicio".

356 Paravicino, Poesías completas, p. 143: "Sube, ¡oh, Madre doncella (asunto grande)": "Oh, María!, ¡oh mar!, ¡oh, dulce abismo" (v. 111).

357 Paravicino, "Plumas y pinceles, Cintia", en ibidem, p. 157, v. 22.

358 Paravicino, "Mal podéis disimularos", en ibidem, p. 192, v. 58.

359 Paravicino, “¿Qué huyes, bruto, y bruto más que fiera?”: “¿Mueres o triunfas?, di” (ibidem, p. 172, v. 13).

360 Paravicino, "Pendiente a morir de un leño”: “¡Este templo misterioso / que cuanto más cae, se erige!" (ibidem, p. 140, vv. 143-144).

361 Paravicino, "Dulce, animado instrumento": "En riesgos así lucientes / muero alegre y advertido / gózome en verme caído" (ibidem, p. 194, vv. 43-45). Sin riesgo de caer, no hay goce.

362 Espinosa, Obra en prosa, p. 265.

363 Diccionario de Autoridades (1780), s. v. zafir o zafiro.

364 Fray Hortensio Paravicino, La Gridonia, ed. Manuel Calderón, Madrid, CSIC, 2009, p. 45 , v. 204. En la misma comedia mienta expresamente la pintura de borrones del Greco: "Amagos eran de Dios / cuantos miraba borrones" (p. 51, vv. 449-450); 'to- 
süave", que no "dura llave"; y sobre todo y como recalca Paravicino, "del Griego aquí lo que pudo encerrarse". Lo que pudo encerrarse porque su pintura es tan blanda que burla todo encierro, sin que haya "nudo" que pueda mantenerla atada; "se aleja”, decía Marías; tiene un sitio en el Cielo: materia hecha de nubes. Caridad del pintar y de lo pintado, que no es otra cosa que la apertura de la forma bajo la forma del compartir la capa: el autorretrato del Greco como San Martín ${ }^{365}$.

Son demasiadas casualidades. Si Góngora no ha copiado el cuadro directamente, sin duda piensa en la ternura del Greco ${ }^{366}$.

dos los borrones que miraba eran amagos maravillosos'. "Amagar" quiere decir, como sabemos, 'hacer demonstración o insinuación de hacer o decir alguna cosa que no se quiere hacer ni decir' (Diccionario de Autoridades, s. v. amagar). Paravicino quiere decir que la pintura de borrones de El Greco no es más que la insinuación de una forma que no quiere ser; basta el amago, "en el amago se ve" (La Gridonia, p. 48, v. 342). De la misma manera, Góngora amaga con decir, pero sin acabar de dar el golpe.

365 Ver al respecto la vieja monografía de Leo Bronstein, El Greco, Nueva York, Harry N. Abrams, 1950: "La generosidad divina y, por lo tanto, ilimitada [unbounded generosity] que encarna el caballero cristiano" (p. 64). Unbounded, 'sin límites', es, en efecto, el adjetivo que corresponde. La caridad del santo es la expresión teológica de la ternura del pincel: la donación de la forma más allá de sus límites.

366 Copiar directamente el cuadro es lo que algunos autores llaman écfrasis descriptiva (Valerie Robillard) o écfrasis referencial (Luz Aurora Pimentel). En cambio, aludir a él se conoce como écfrasis atributiva (Robillard) o écfrasis referencial genérica (Pimentel). Si el retrato ecuestre de las Soledades no es la écfrasis descriptiva del San Martín y el pobre de El Greco, sin duda es su écfrasis atributiva. Ver al respecto Valerie Robillard, "En busca de la écfrasis (un acercamiento intertextual)", en Entre artes, entre actos: écfrasis e intermedialidad, eds. Susana González Aktories e Irene Artigas Albarelli, Coyoacán (México), Universidad Nacional Autónoma de México, 2011, pp. 27-50; y Luz Aurora Pimentel, "Écfrasis y lecturas iconotextuales", Poligrafias, IV (2003), pp. 205-215. Kibédi Varga prefiere el término Bildgedicht o "poema plástico": "Bildgedicht se refiere más específicamente a poemas inspirados en un cuadro o un pintor; puede verse como una variación verbal libre, mientras que la écfrasis originalmente se aplicaba a una descripción exacta que pretendía, hasta cierto punto, evocar y sustituir el cuadro mismo". Ver Aron Kibédi Varga, "Criterios para describir las relaciones entre palabra e imagen", en Literatura y pintura, ed. Antonio Monegal, Madrid, Arco/Libros, 2000, pp. 109-135 (p. 125). 


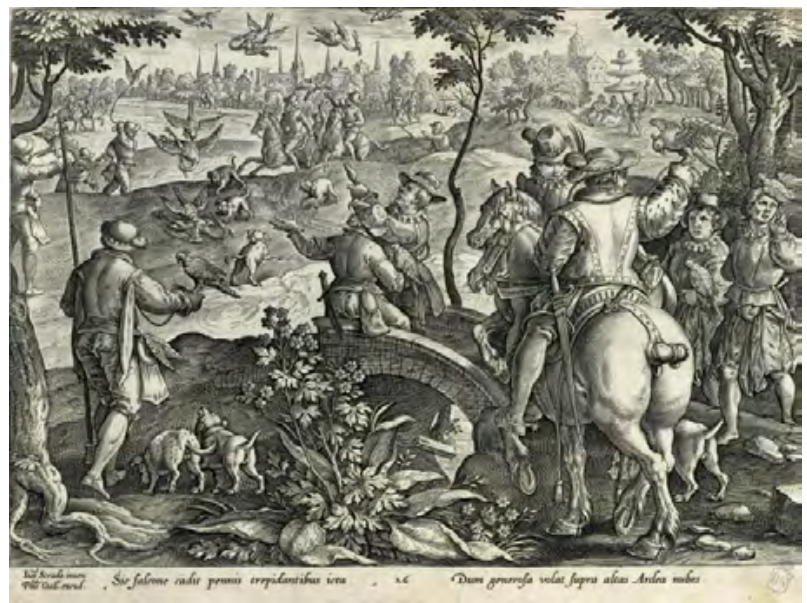

Figura 1

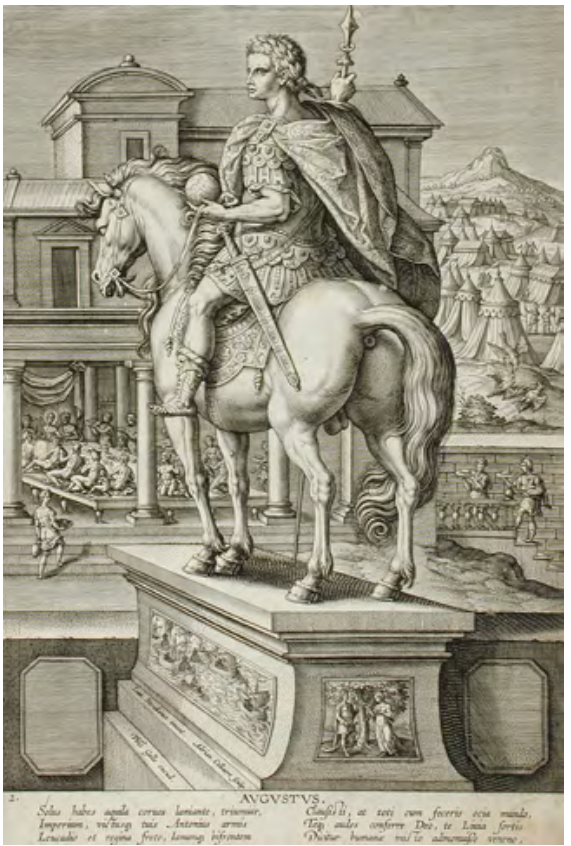

Figura 2 
Humberto Huergo Cardoso, "Si en miembros no robusto": el retrato ecuestre de las Soledades y la maniera suave

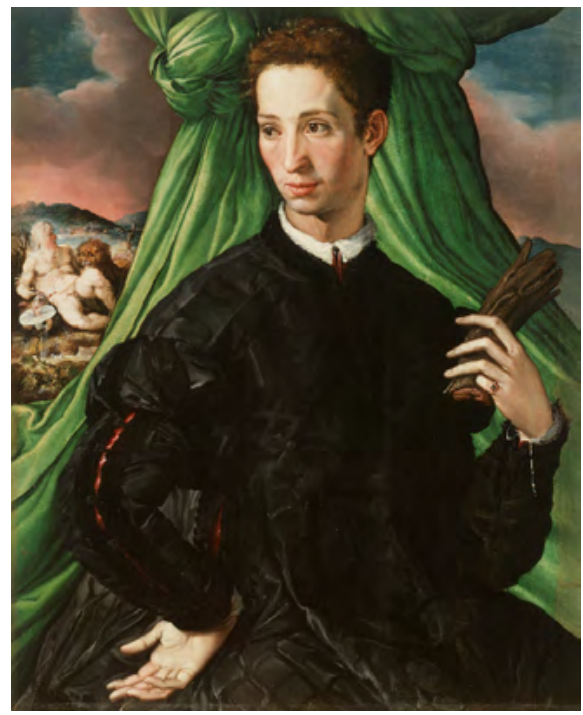

Figura 3

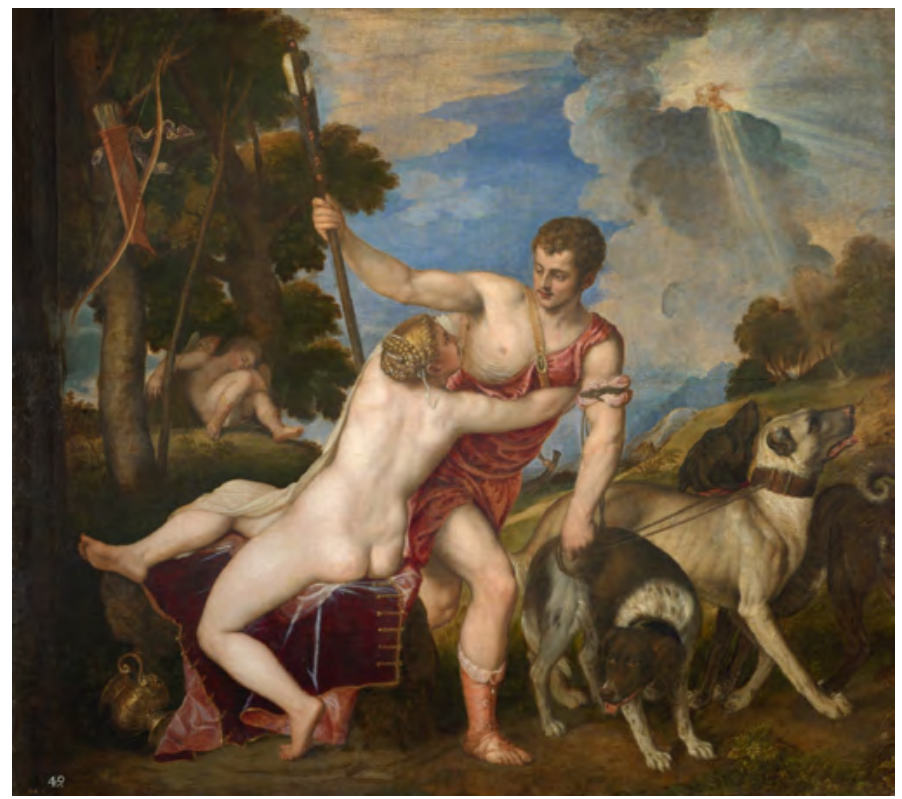

Figura 4 
Humberto Huergo Cardoso, "Si en miembros no robusto": el retrato ecuestre de las Soledades y la maniera suave

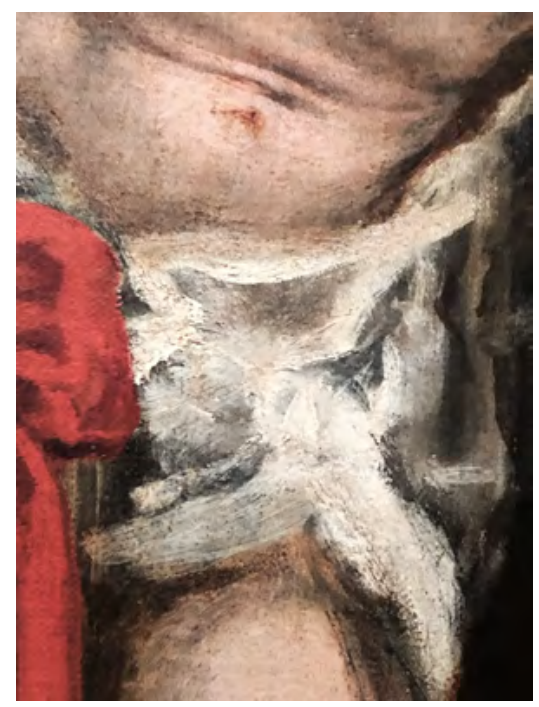

Figura 5

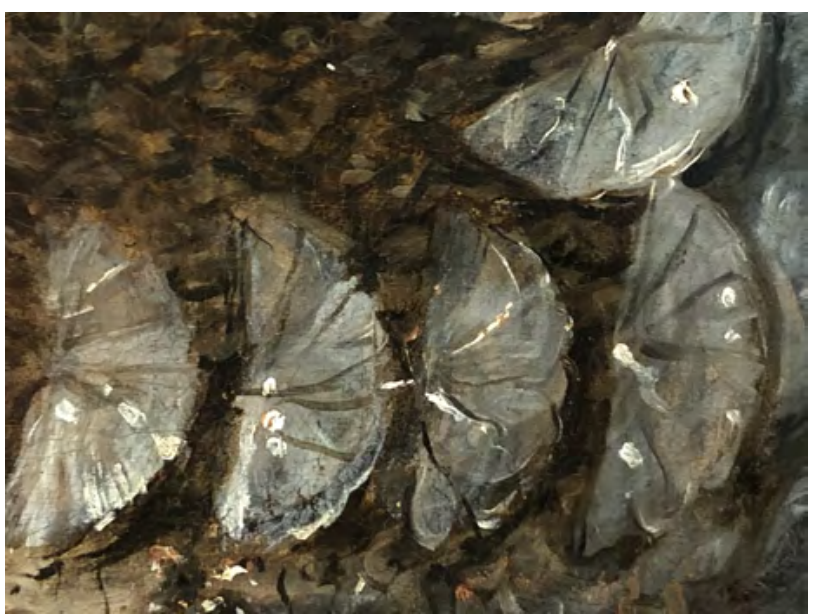

Figura 6 
Humberto Huergo Cardoso, "Si en miembros no robusto": el retrato ecuestre de las Soledades y la maniera suave

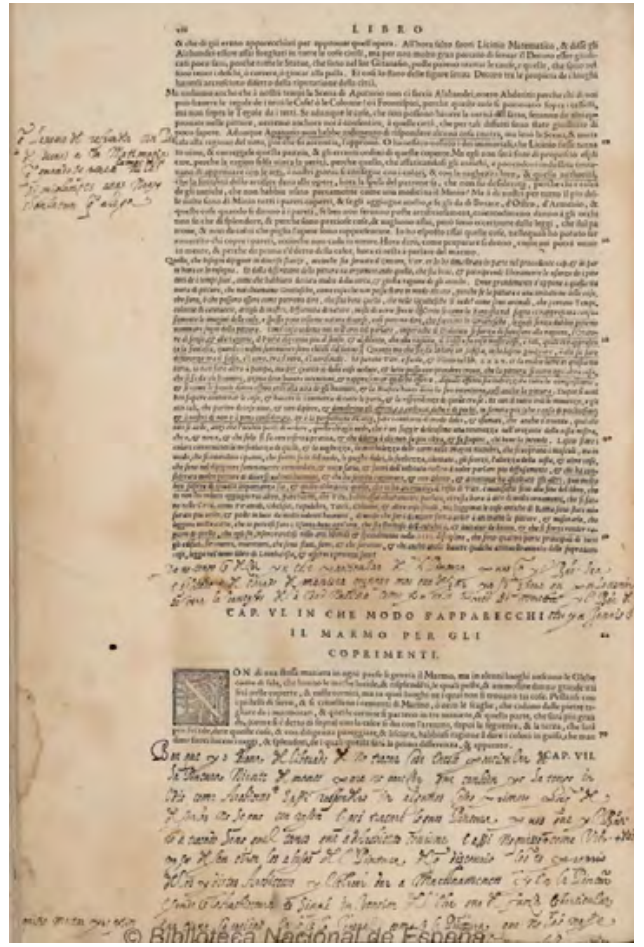

Figura 7

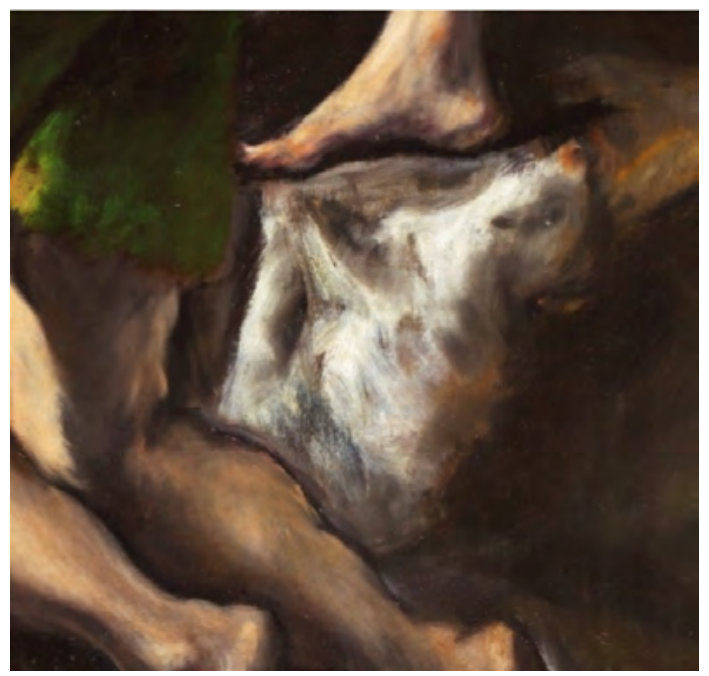

Figura 8 
Humberto Huergo Cardoso, "Si en miembros no robusto": el retrato ecuestre de las Soledades y la maniera suave

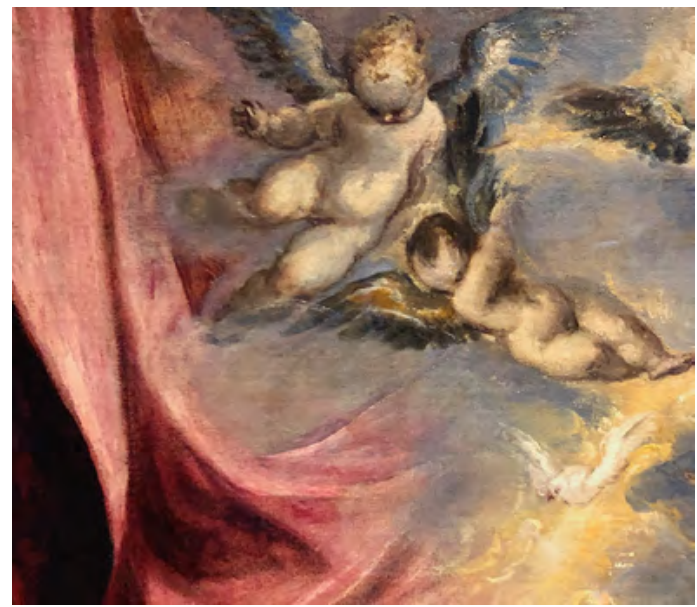

Figura 9

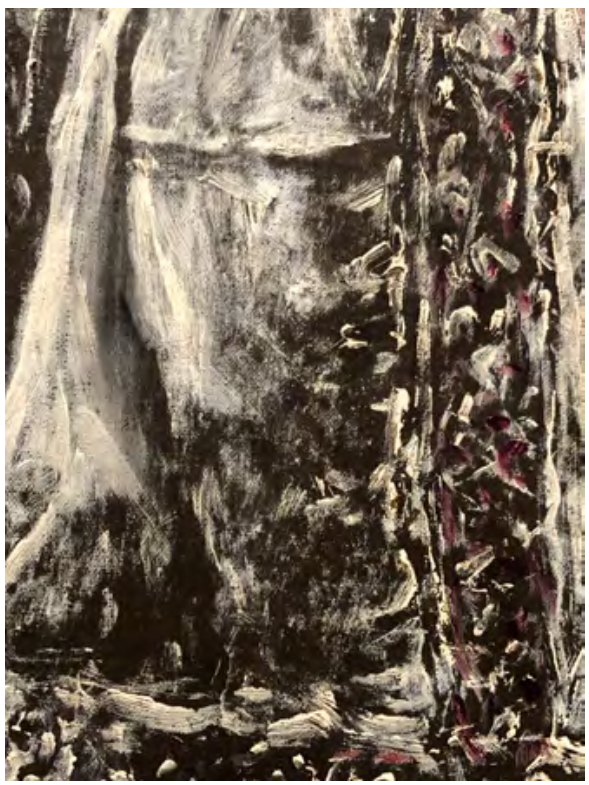

Figura 10 
Humberto Huergo Cardoso, "Si en miembros no robusto": el retrato ecuestre de las Soledades y la maniera suave

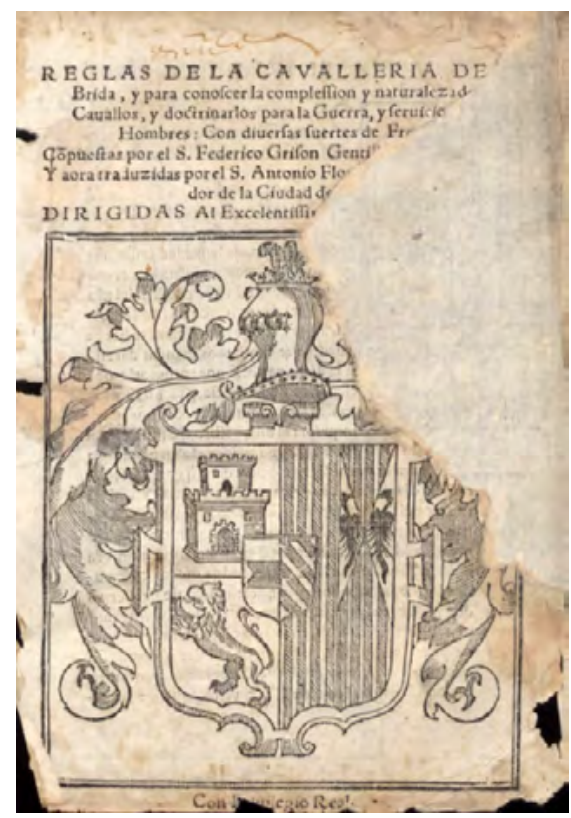

Figura 11

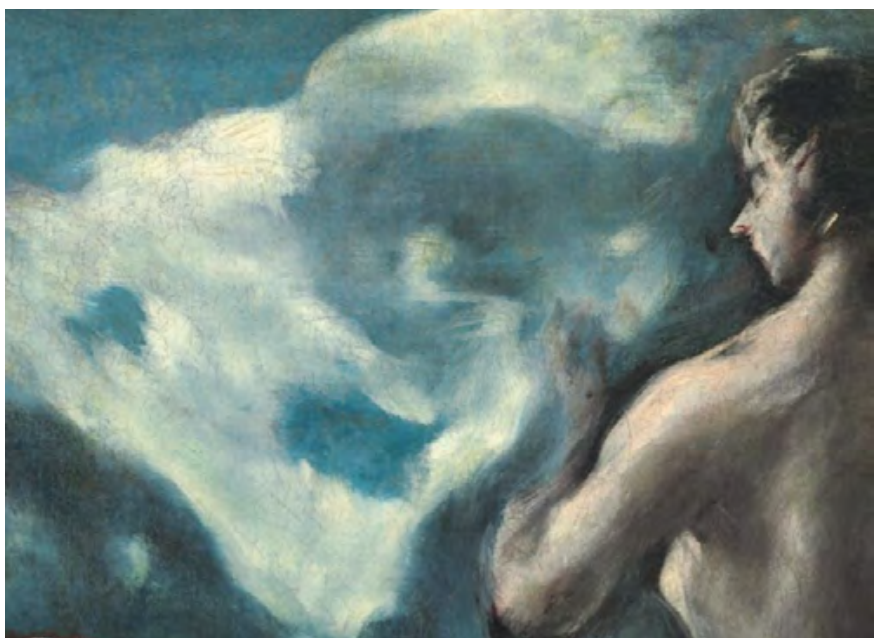

Figura 12 


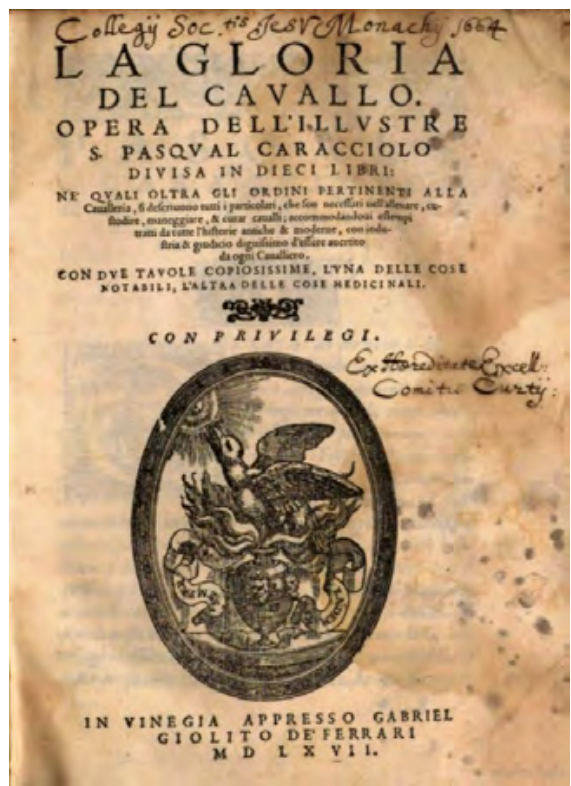

Figura 13

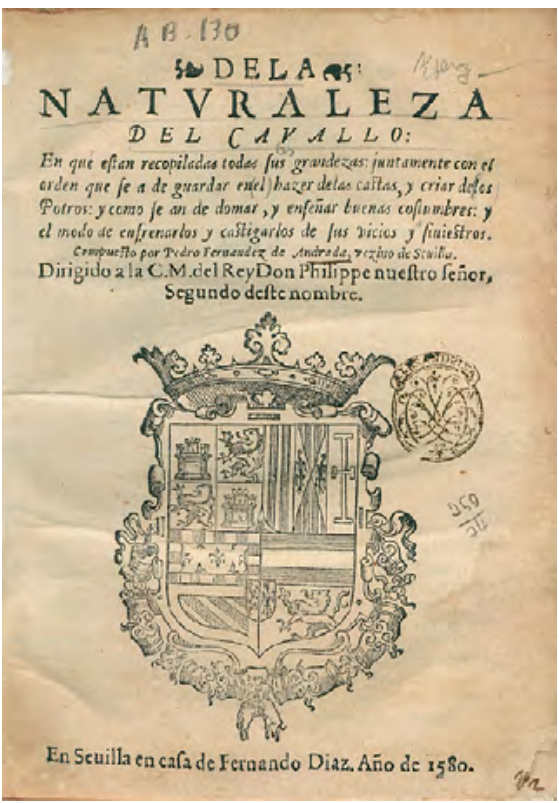

Figura 14 
Humberto Huergo Cardoso, "Si en miembros no robusto": el retrato ecuestre de las Soledades y la maniera suave

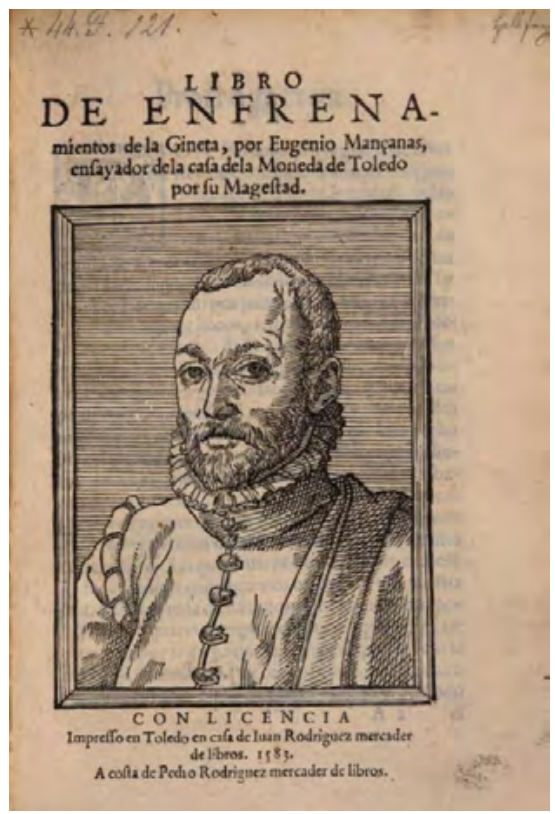

Figura 15

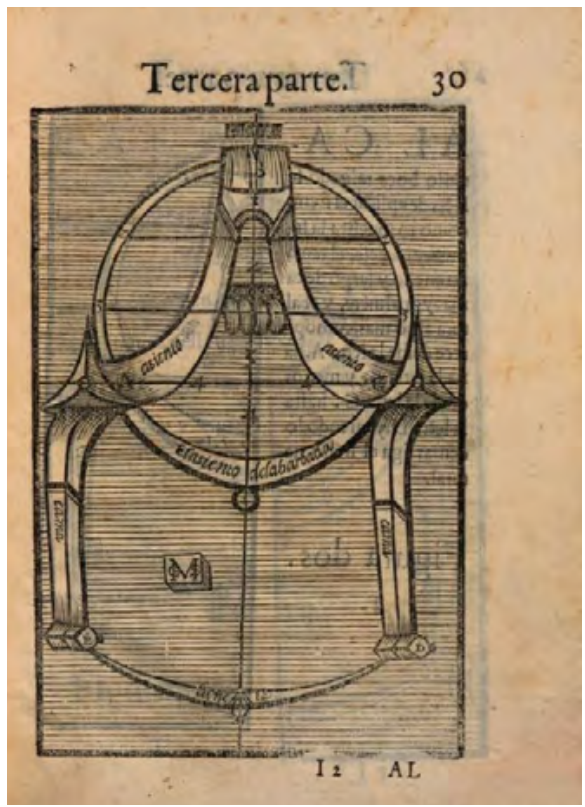

Figura 16 
Humberto Huergo Cardoso, "Si en miembros no robusto": el retrato ecuestre de las Soledades y la maniera suave

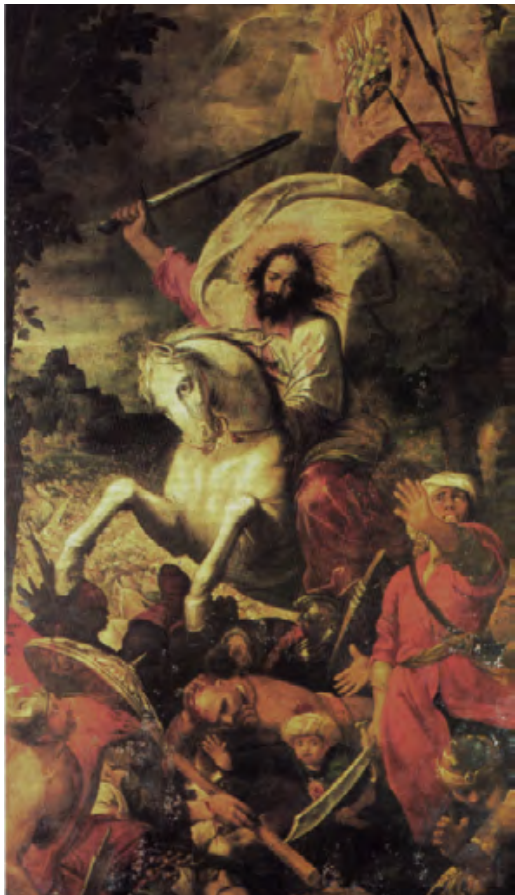

Figura 17

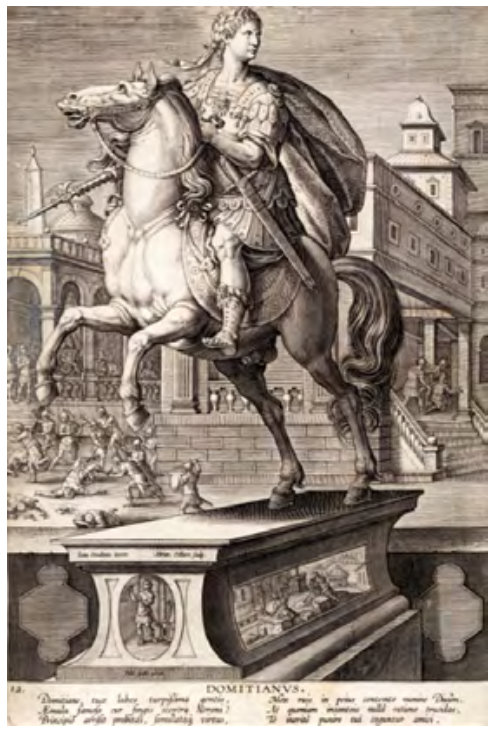

Figura 18 
Humberto Huergo Cardoso, "Si en miembros no robusto": el retrato ecuestre de las Soledades y la maniera suave

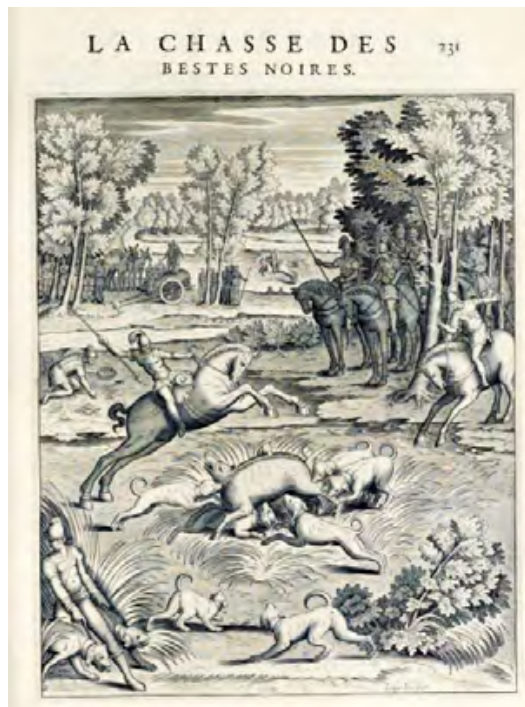

Figura 19

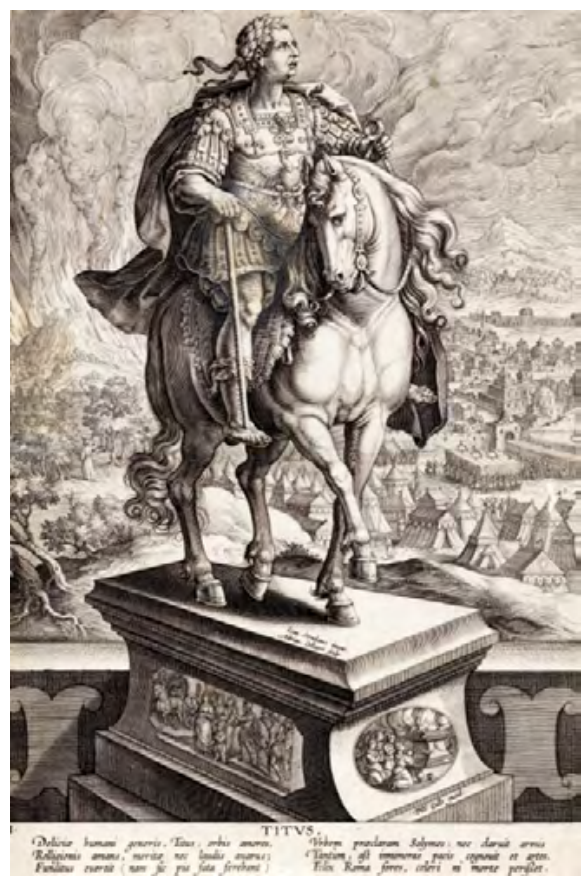

Figura 20 
Humberto Huergo Cardoso, "Si en miembros no robusto": el retrato ecuestre de las Soledades y la maniera suave

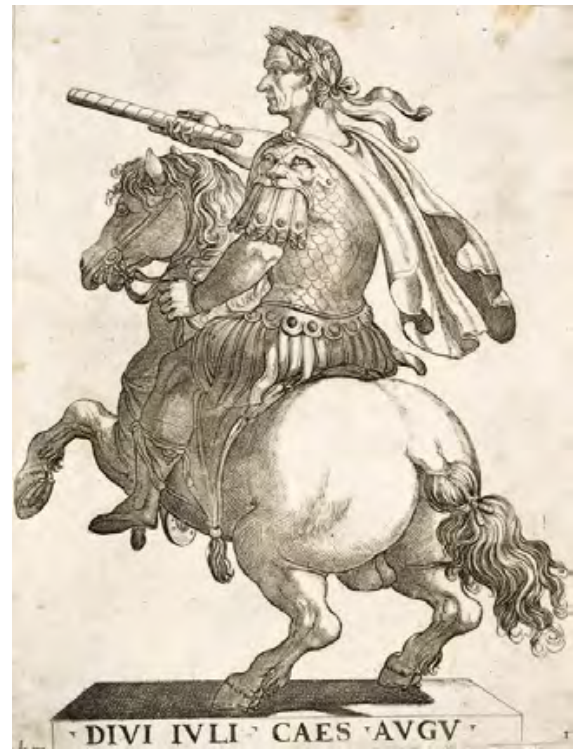

Figura 21

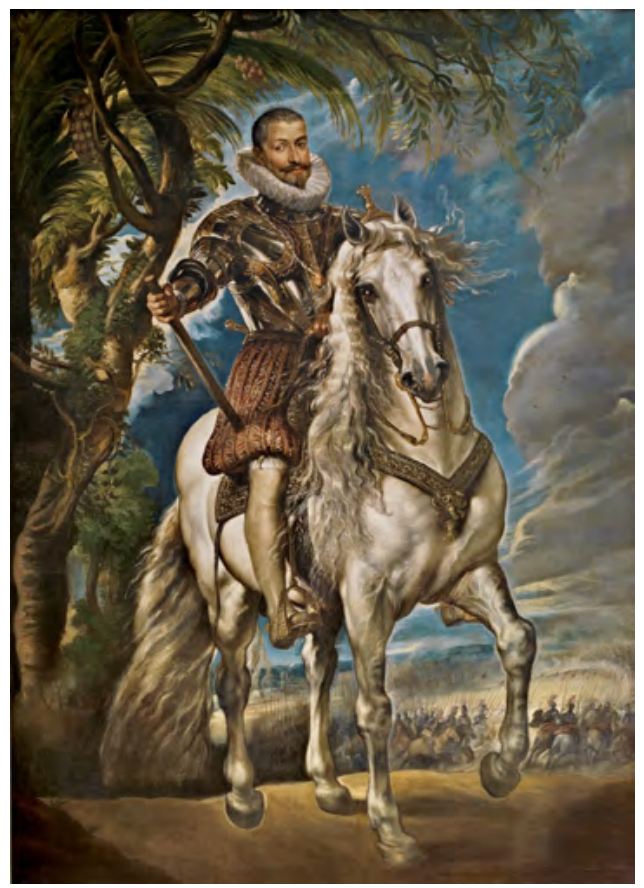

Figura 22 
Humberto Huergo Cardoso, "Si en miembros no robusto": el retrato ecuestre de las Soledades y la maniera suave

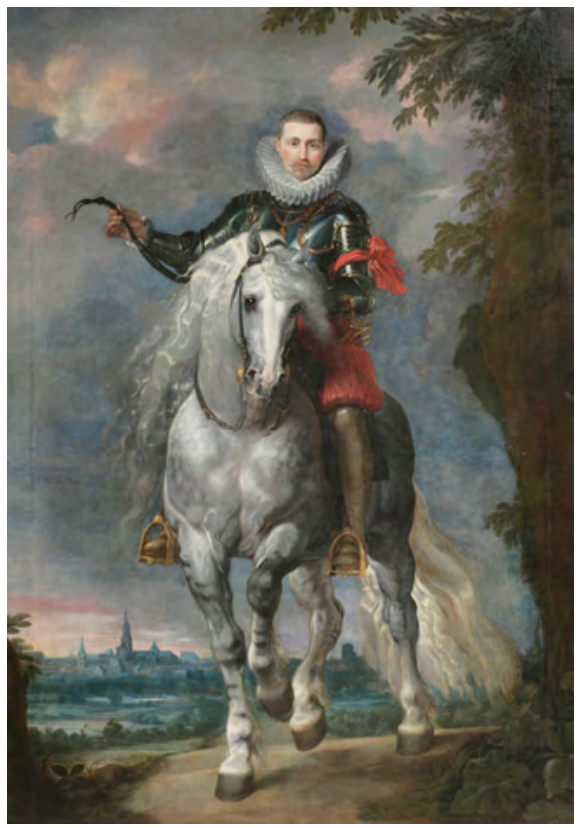

Figura 23

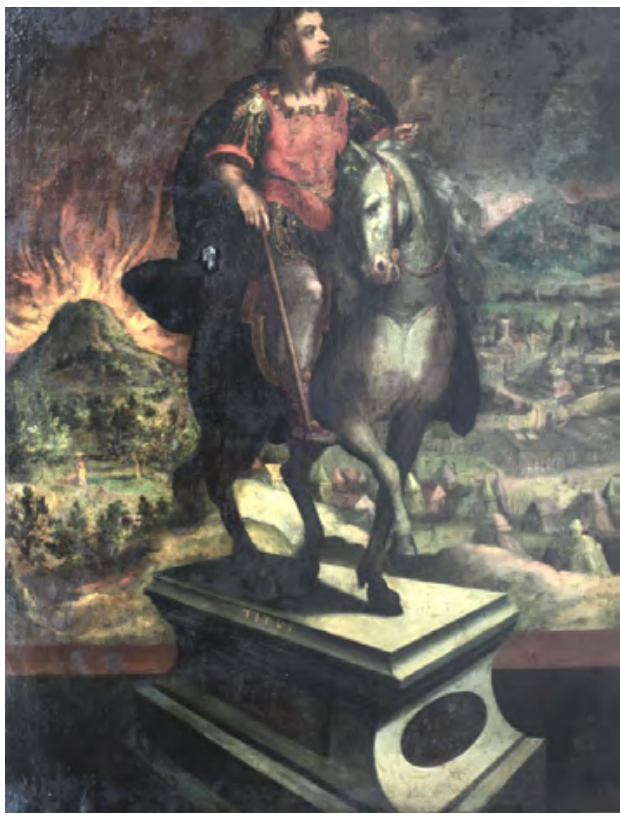

Figura 24 
Humberto Huergo Cardoso, "Si en miembros no robusto": el retrato ecuestre de las Soledades y la maniera suave

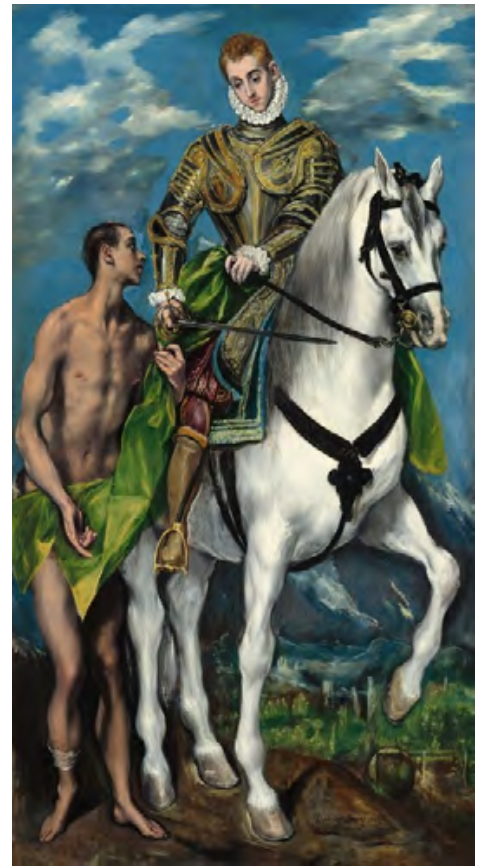

Figura 25

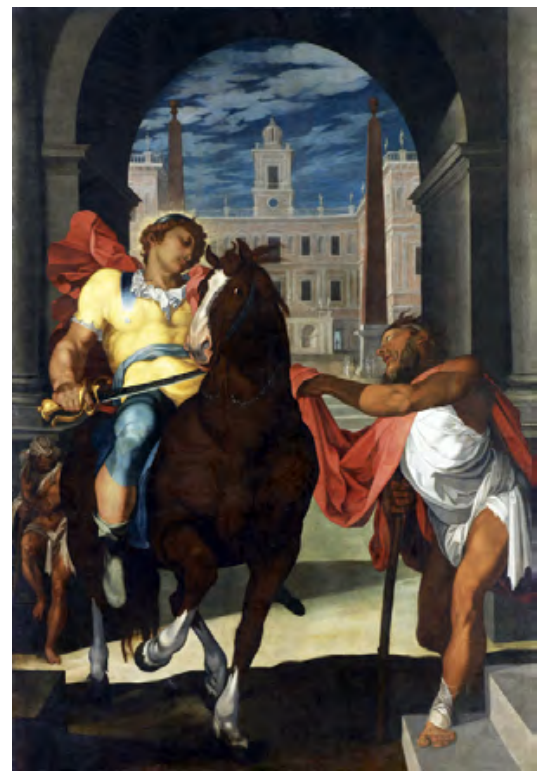

Figura 26 
Humberto Huergo Cardoso, "Si en miembros no robusto": el retrato ecuestre de las Soledades y la maniera suave

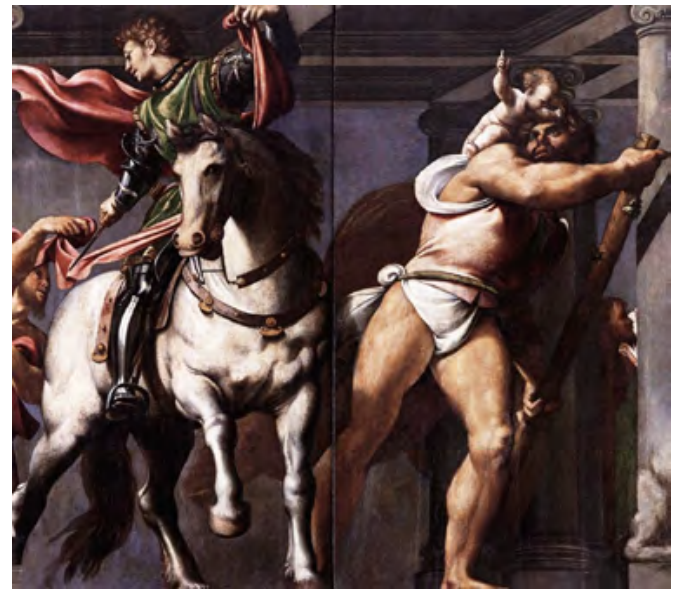

Figura 27

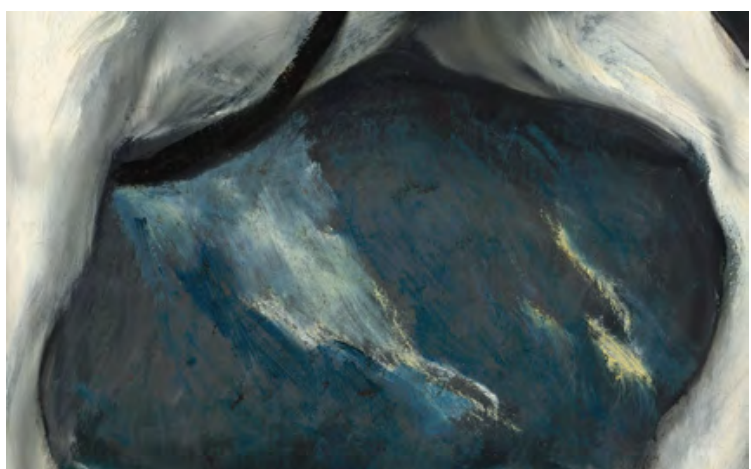

Figura 28

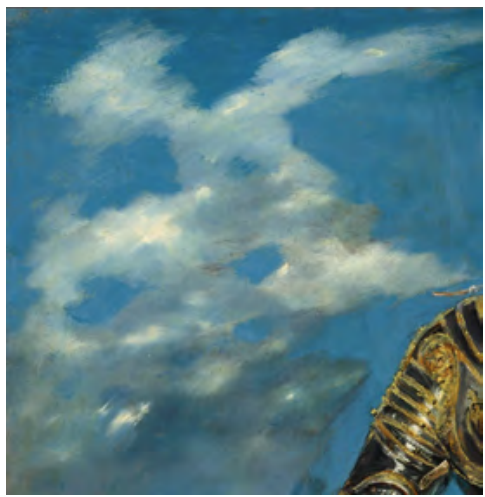

Figura 29 
Humberto Huergo Cardoso, "Si en miembros no robusto": el retrato ecuestre de las Soledades y la maniera suave

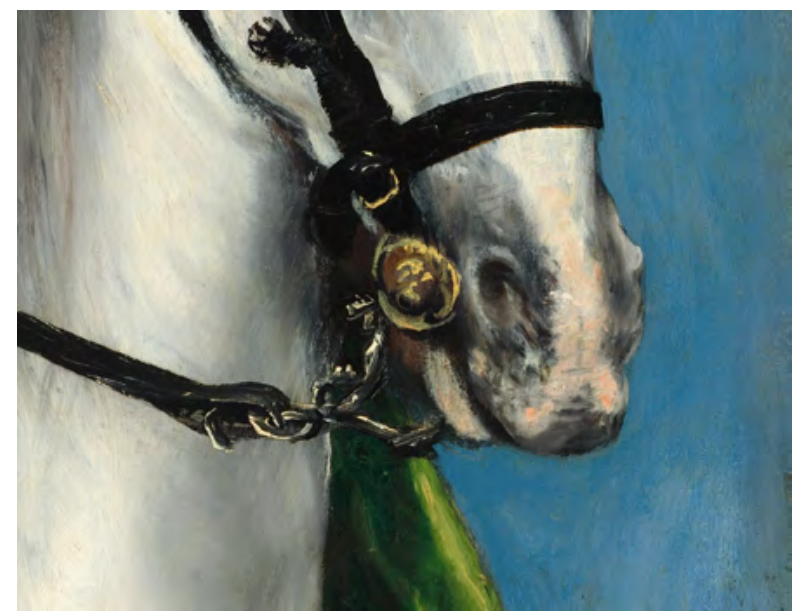

Figura 30

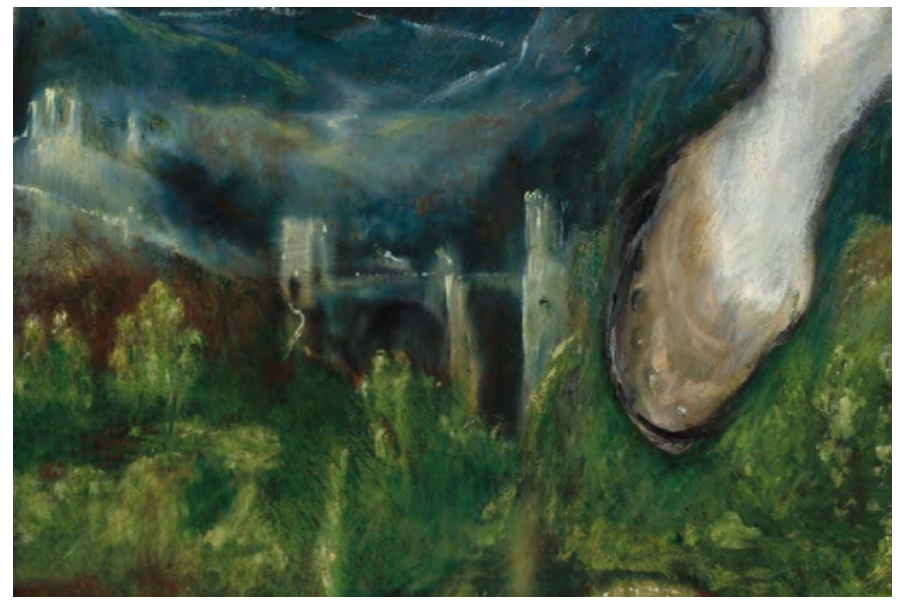

Figura 31 